\title{
Significance of Frequencies, Compositions, and/or Antileukemic Activity of (DC-stimulated) Invariant NKT, NK and CIK Cells on the Outcome of Patients With AML, ALL and CLL
}

\author{
Corinna L. Boeck,* Daniel C. Amberger,* Fatemeh Doraneh-Gard,* \\ Wishnu Sutanto,* Thomas Guenther,* Joerg Schmohl, $\dagger$ Friedhelm Schuster, $\neq$ \\ Helmut Salih, $\dagger$ Florian Babor, $\$$ Arndt Borkhardt, $\$$ and Helga Schmetzer*
}

\begin{abstract}
Summary: Invariant natural killer T (iNKT)/natural killer (NK)/ cytokine-induced killer (CIK) cells are important for immune surveillance. (I) Novel combinations of antibody 6B11 (targeting the V $\alpha 24-\mathrm{J} \alpha 18$-invariant T-cell receptor) with $\mathrm{CD} 4 / \mathrm{CD} 8 / \mathrm{CD} 1 \mathrm{~d} /$ $\mathrm{V} \alpha 24$ for iNKT subset detection and "T/NK cell-like"-iNKT subsets were defined. Compared with healthy peripheral blood mononuclear cells (MNC) (significantly) lower proportions of iNKT cells $\left(6 \mathrm{~B} 11^{+} / 6 \mathrm{~B} 11^{+} \mathrm{CD} 3{ }^{+} / 6 \mathrm{~B} 11^{+} \mathrm{CD} 161{ }^{+}\right)$, NK cells $\left(\mathrm{CD}^{-}{ }^{-} \mathrm{CD} 56^{+} / \mathrm{CD}^{-}{ }^{-} \mathrm{CD} 161^{+}\right)$, and $\mathrm{CIK}$ cells $\left(\mathrm{CD} 3{ }^{+} \mathrm{CD} 56^{+} /\right.$ $\left.\mathrm{CD} 3{ }^{+} \mathrm{CD}_{161}{ }^{+}\right)$were found in peripheral blood $\mathrm{MNC}$ from acute myeloid (AML)/acute myeloid, lymphoid (ALL)/chronic lymphoid leukemia (CLL) patients in acute disease stages. Subtyping of iNKT cells revealed (significantly) higher proportions of $\mathrm{CD}^{+}$ $\mathrm{T}$ cells and $\mathrm{CD} 161^{+} \mathrm{NK}$ cells in AML/ALL/CLL expressing 6B11 compared with healthy MNC. Prognostic evaluations showed higher proportions of iNKT/NK/CIK cells in favorable AML subgroups (younger age, primary, no extramedullary disease, achievement/maintenance of complete remission) or adult ALL and CLL patients. (II) iNKT/NK/CIK cell frequencies increased after (vs. before) mixed lymphocyte cultures of T-cell-enriched immune reactive cells stimulated with $\mathrm{MNC}$ /whole blood with or without pretreatment with "cocktails" (dendritic cells generating methods/ kits inducing blasts' conversion to leukemia-derived dendritic cells from AML patients). Individual "cocktails" leading to "highest" iNKT cell frequencies could be defined. Antileukemic blast lytic activity correlated significantly with frequencies of iNKT/NK/CIK cells. In summary healthy MNC show significantly more iNKT/ $\mathrm{NK} / \mathrm{CIK}$ cells compared with AML/ALL/CLL MNC, a shift in the iNKT cell composition is seen in healthy versus leukemic samples and iNKT/NK/CIK cell-proportions in AML/ALL/CLL MNC samples correlate with prognosis. "Cocktail"-treated AML blasts lead to higher iNKT/NK/CIK cell frequencies and samples with antileukemic activity show significantly higher frequencies of iNKT/NK/CIK cells. Proportions of iNKT/NK/CIK cells should regularly be evaluated in AML/ALL/CLL diagnosis panels for quantitative/prognostic estimation of individual patients' antileukemic potential and their role in dendritic cells/leukemia-derived dendritic cells triggered immune surveillance.
\end{abstract}

Received for publication January 27, 2017; accepted March 30, 2017. From the *Department of Hematopoetic Cell Transplantation, Medicine Department 3, University Hospital of Munich, Munich; $\dagger$ Department of Hematology and Oncology, University Hospital of Tuebingen, Tuebingen; and $\ddagger$ Department of Pediatric Hematology, Oncology and Clinical Immunology, University Hospital of Duesseldorf, Duesseldorf, Germany.

C.L.B. and D.C.A. contributed equally.

Reprints: Helga Schmetzer, Department of Hematopoetic Transplantations,

Klinikum Grosshadern, Medicine Department 3, University of Munich

Marchioninistr, 15, Munich 81377, Germany

(e-mail: helga.schmetzer@med.uni-muenchen.de).

Copyright (C) 2017 Wolters Kluwer Health, Inc. All rights reserved.
Key Words: iNKT, NK, CIK, DC leu, AML, ALL, CLL

(J Immunother 2017;40:224-248)

A cute myeloid (AML), lymphoid (ALL) or chronic lymphoid leukemia (CLL) are clonal diseases with uncontrolled proliferation of myeloid or lymphoid blasts. Prognostic rates of complete remission (CR) and survival depend on grade of anemia, thrombocytopenia, white blood cell expansion and karyotypes, resulting in different therapeutic strategies. Therapy for AML, ALL, and CLL patients with advanced stages consists of chemotherapy and stem cell transplantation (SCT), but the rate of early failures and relapses is still unsatisfying. AML patients can be categorized into 3 risk groups. ${ }^{1}$ ALL patients are primarily children with survival rates of about $90 \%$ and higher incidences for an assignment to standard risk-groups compared with adult patients with higher tendencies for high risk leukemia. ${ }^{2}$ CLL usually occurs in elderly patients and these are classified in Binet-staging groups: Binet A (early), $\mathrm{B}$ (intermediate), and C (advanced stage). ${ }^{3}$

Effective immune surveillance of patients with hematologic malignancies such as leukemia is mediated by arms of the innate and adaptive immune system. The innate immune system includes macrophages, dendritic cells (DC), and natural killer (NK) cells, which respond quickly to an immunologic threat. ${ }^{4} \mathrm{NK}$ cells have the ability to kill tumor cells without activation, arise from $\mathrm{CD} 34^{+}$bone marrow (BM) cells and are defined as CD ${ }^{-} \mathrm{CD} 56^{+} \mathrm{CD} 161{ }^{+} .^{5}$ The adaptive immune system includes $\mathrm{T}$ and $\mathrm{B}$ cells, which mediate tumor immunity by antigen-specific responses and provide long-lasting protection by effector-memory responses. $\mathrm{T}$ cells $\left(\mathrm{CD} 3^{+}\right)$express $\mathrm{T}$-cell receptors (TCR) that recognize (peptide)-antigens on blasts, which have to be presented by majorhistocompatibility complex (MHC)-I or MHC-II molecules via antigen-presenting cells. ${ }^{4}$ A specialty of myeloid blasts is, that they can differentiate to leukemia-derived dendritic cells $\left(\mathrm{DC}_{\text {leu }}\right)$, presenting the complete leukemic antigen repertoire, thereby specifically and efficiently activating an antileukemic T-cell response. ${ }^{6-8}$ $\mathrm{T}$ cells occur in various differentiation and functional subsets [eg, naive $\left(\mathrm{T}_{\text {naive }}, \mathrm{CD} 45 \mathrm{RO}^{-}\right)$, non-naive $\left(\mathrm{T}_{\text {non-naive }}\right.$, $\left.\mathrm{CD} 45 \mathrm{RO}^{+}\right)$, central-memory $\left(\mathrm{T}_{\mathrm{cm}}, \mathrm{CD} 45 \mathrm{RO}^{+} \mathrm{CCR} 7^{+}\right)$, effector/memory $\left(\mathrm{T}_{\text {eff-em }}, \mathrm{CD} 4 \mathrm{RO}^{+} \mathrm{CCR}^{-}\right)$, and regulatory $\left.\left(\mathrm{T}_{\text {reg }}, \quad \mathrm{CD} 25^{+}+\mathrm{CD} 127^{+ \text {low }}\right)\right] \cdot \cdot^{9,10}$ Furthermore, other cells at the interface of the innate and the adaptive immune system are important mediators in antitumor, 
autoimmune, and antimicrobial responses and tumor surveillance ${ }^{4}$ : cytokine-induced killer (CIK) cells have phenotypic and functional features of $\mathrm{T}$ and NK cells as they are $\mathrm{CD}^{+}{ }^{+} \mathrm{CD} 56{ }^{+} \mathrm{CD} 161^{+}$, they are expandable in culture like T cells; however, they do not recognize cells via TCR or MHC molecules as T cells. ${ }^{5}$ NKT cells are a heterogenous lymphoid population, that bridge innate and adaptive immunity and, in general, share properties of $\mathrm{T}$ and $\mathrm{NK}$ cells. Similar to NK cells, NKT cells have the ability to react rapidly to antigenic stimulation by quickly secreting large amounts of cytokines and chemokines within minutes to hours. ${ }^{4}$ In addition, they activate DC, NK, and CD4 ${ }^{+} /$ $\mathrm{CD} 8{ }^{+} \mathrm{T}$ cells, thereby triggering innate and adaptive immune responses. ${ }^{11}$ Similar to $\mathrm{T}$ cells, NKT cells respond via the TCR, recognizing glycolipid antigens presented by the MHC-like molecule CD1d. TCR from NKT cells react with many self and foreign antigens, while the TCR from $\mathrm{T}$ cells only reacts with one epitope. ${ }^{4}$ It was shown, that the positive selection of NKT cells is strictly dependent on CD1d during ontogeny in the thymus and therefore CD1d restriction has become the defining characteristic of NKT cells (NK markers are only used to define subpopulations). ${ }^{12}$ The NKT cell population consists of many phenotypically and functionally diverse subsets, which are subdivided either by surface markers, TCR, tissue location, antigen recognition or by effector functions. Concerning their heterogenous TCR rearrangements, NKT cells are divided into 2 main groups: type-I NKT cells are referred to as invariant NKT cells (iNKT cells) as they express a semiinvariant TCR, characterized in humans by $\mathrm{V} \alpha 24-\mathrm{J} \alpha 18$ and $\mathrm{V} \beta 11$, while $\beta$-chains have a limited variety. In contrast, NKT cells that do not express this semi-invariant TCR are referred to as type-II NKT cells, which are less well studied than iNKT cells. ${ }^{11}$ iNKT cells are known for enhancement of tumor immunity, while type-II NKT cells are known for suppression of it, resulting in opposed roles in tumor immunity and crossregulate of each other. ${ }^{4}$

NKT cells originate from a precursor pool of CD4 ${ }^{+}$ $\mathrm{CD}^{+}{ }^{+}$double positive thymocytes, that have to undergo diverse $T C R$ gene rearrangements, are then positively selected by $\mathrm{CD} 1 \mathrm{~d}^{+}$double positive thymocytes in the thymic cortex, undergo 4 differentiation and maturation steps and then differentiate into mature NKT cells. Expression of CD4 and CD8 allow a subdivision of NKT cells in different subpopulations: a majority is CD4 ${ }^{+}(90 \%$ in mice), the remainder is $\mathrm{CD} 4^{-} \mathrm{CD} 8^{-}$double negative and a small population is $\mathrm{CD} 8 \alpha \alpha^{+}$and $\mathrm{CD} 8 \alpha \beta^{+}$, but $\mathrm{CD} 8{ }^{+}$ subsets only exist in humans (not in mice), predominantly in healthy persons with latent Epstein-Barr virus infection. ${ }^{12}$

The evaluation of human iNKT cells is challenging, as their frequency in peripheral blood (PB) is very low. Classically, iNKT cells have been identified using CD1d tetramers loaded with $\alpha$-galactosylceramide or monoclonal antibodies (moAbs) against the V $\alpha 24$ and V $\beta 11$ chains, what however, can lead to an overestimation of iNKT cells, as noninvariant, non-CD1d restricted $\mathrm{V} \alpha 24^{+} \mathrm{T}$ cells can also pair with V $\beta 11$. Recently iNKT cells were shown to be identified using the moAb 6B11, which recognizes the invariant CDR3 loop of their V $\alpha 24 \mathrm{~J} \alpha 18$ TCRrearrangement with high specificity and sensitivity. ${ }^{13}$ CD161 (NKR-P1A) is a C-type lectin receptor and is an important marker for NK and iNKT cell identification as all human NK cells, high proportions of iNKT cells, and $\mathrm{T}_{\mathrm{eff} / \mathrm{em}}$ and $\mathrm{T}_{\mathrm{cm}}$ express it. Recently it was shown, that $\mathrm{CD} 161^{+} \mathrm{T}$ cell subsets are highly functional during infections: low frequencies correlate with higher incidence of (viral) infections. ${ }^{14-18}$

Considering that the antileukemic function of $\mathrm{T}$ cells can be stimulated by $\mathrm{DC}_{\text {leu }}, 9,10$ our supposition is that the iNKT/NK and CIK cell activity might also be enhanced under $\mathrm{DC} / \mathrm{DC}_{\text {leu }}$ stimulation. $\mathrm{DC}_{\text {leu }}$ can be generated in vitro by converting myeloid leukemia cells in mononuclear cells (MNC) or whole blood (WB) using DCgenerating methods/kits ("cocktails," containing immune response modifiers in combination with cytokines) and represent as well leukemic (eg, CD13, CD33, CD117) and DC antigens (eg, CD80, CD83, CD86). ${ }^{19,20}$

Physiological conditions in the stem cell niche of the $\mathrm{BM}$ as well as in the $\mathrm{PB}$ are hypoxic with Oxygen $\left(\mathrm{O}_{2}\right)$ concentrations between $0.1 \%$ and $0.6 \%$ in the BM, $12 \%$ in arterial blood and $4 \%-15 \%$ in $\mathrm{PB} .{ }^{21,22}$ Previous studies suggest an influence of the partial pressure of oxygen $\left(\mathrm{pO}_{2}\right)$ on several pathophysiological mechanisms. ${ }^{23,24}$ However, hematopoiesis takes place under physiologically low $\mathrm{pO}_{2} /$ $\mathrm{O}_{2}$-concentration and hematopoietic cells are continually exposed to dynamic $\mathrm{pO}_{2}$-values. ${ }^{25}$ Moreover, a recent in vitro study showed that hypoxia might have an enhancing effect on NK cells. ${ }^{26}$

The aim of this study was (1) to test the suitability of different markers and combinations (Table 1) to characterize and quantify iNKT, NK, and CIK cells/subsets; (2) to quantify iNKT, NK, and CIK subsets in MNC from patients with AML, ALL, and CLL compared with healthy controls; (3) to correlate findings with disease entities and prognostic subgroups; (4) to quantify iNKT, NK, and CIK subsets under stimulation with $\mathrm{DC} / \mathrm{DC}_{\text {leu }}$, that are generated from WB/MNC with various "cocktails".

\section{MATERIALS AND METHODS}

\section{Sample Collection}

After obtaining informed consent, heparinized peripheral WB samples were taken from patients in acute phases of AML, ALL, CLL, and from healthy controls. MNC were prepared from WB samples by density gradient centrifugation using the Ficoll-Hypaque technique (Biocoll separating solution; Biochrom, Berlin, Germany) with a density gradient of $1.077 \mathrm{~g} / \mathrm{mL}$. MNC were washed and suspended in phosphate-buffered saline (PBS; Biochrom). CD3 ${ }^{+}$T cells were enriched using the MACS technology (Milteney Biotech, Bergisch Gladbach, Germany). The purity of $\mathrm{CD}^{+} \mathrm{T}$ cells was on average $(\varnothing)$ ) $89 \%$ (range: $69 \%-98 \%$ ). Cells were quantified using Neubauer counting chambers, used directly or frozen and thawed according to standardized protocols.

\section{Patients' Characteristics and Diagnostics}

\section{Patients and Samples Included for Surface Marker Expression Analyses on Thawed Cells}

Quantitative and qualitative characterizations of several immune reactive cells were performed with thawed MNC from patients with blast-rich phases of AML $(\mathrm{n}=23), \operatorname{ALL}(\mathrm{n}=19)$, and CLL $(\mathrm{n}=21)$. Samples were provided by the University-Hospitals of Tubingen, Dusseldorf, Munich, Oldenburg and Augsburg. Cells were obtained by aspirates of $\mathrm{PB}$ or $\mathrm{BM}$, which were anticoagulated with heparin after patients' written informed consent in accordance with the Helsinki protocol and the local Ethic Committee (Pettenkoferstr. 8a, 80336 München, 


\begin{tabular}{|c|c|c|c|c|c|c|}
\hline & Names of Subgroups & Referred To & Surface Marker & Abbreviation & Explanatory Note/Permise & References \\
\hline \multirow{21}{*}{$\mathrm{T}$ cells } & $\mathrm{CD}^{+}$pan-T cells & $\mathrm{MNC}(\mathrm{WB})$ or MLC1* & $\mathrm{CD}^{+}$ & $\mathrm{CD}^{+} / \mathrm{MNC}(\mathrm{WB})$ or $\mathrm{MLC}$ & & Schick et al $^{10}$ \\
\hline & $\mathrm{CD}^{+}$-coexpressing $\mathrm{T}$ cells & $\mathrm{MNC}(\mathrm{WB})$ or MLC & $\mathrm{CD}^{+} \mathrm{CD}^{+}$ & $\mathrm{CD}^{+} / \mathrm{MNC}(\mathrm{WB})$ or $\mathrm{MLC}$ & $\mathrm{CD} 4^{+} \mathrm{T}$ cells & Schick et al ${ }^{10}$ \\
\hline & $\mathrm{CD}^{+}$-coexpressing $\mathrm{T}$ cells & $\mathrm{CD}^{+}$ & $\mathrm{CD}^{+} \mathrm{CD}^{+}$ & $\mathrm{CD}^{+} / \mathrm{CD}^{+}$ & $\mathrm{CD}^{+} \mathrm{T}$ cells & Schick et al ${ }^{10}$ \\
\hline & $\mathrm{CD}^{+}$-coexpressing $\mathrm{T}$ cells & $\mathrm{MNC}(\mathrm{WB})$ or MLC & $\mathrm{CD}^{+} \mathrm{CD}^{+}$ & $\mathrm{CD}^{+} / \mathrm{MNC}(\mathrm{WB})$ or $\mathrm{MLC}$ & $\mathrm{CD} 8^{+} \mathrm{T}$ cells & Schick et al ${ }^{10}$ \\
\hline & $\mathrm{CD}^{+}$-coexpressing $\mathrm{T}$ cells & $\mathrm{CD}^{+}$ & $\mathrm{CD}^{+} \mathrm{CD}^{+}$ & $\mathrm{CD}^{+} / \mathrm{CD}^{+}$ & $\mathrm{CD}^{+} \mathrm{T}$ cells & Schick et al ${ }^{10}$ \\
\hline & Naive $\mathrm{T}$ cells & $\mathrm{MNC}(\mathrm{WB})$ or MLC & $\mathrm{CD}^{+} \mathrm{CD}^{+} 5 \mathrm{RO}^{-}$ & $\mathrm{T}_{\text {naive }} / \mathrm{MNC}(\mathrm{WB})$ or MLC & Unprimed T cells & Vogt et al ${ }^{9}$ \\
\hline & Naive T cells & $\mathrm{CD}^{+}$ & $\mathrm{CD}^{+} \mathrm{CD}^{+} 5 \mathrm{RO}^{-}$ & $\mathrm{T}_{\text {naive }} / \mathrm{CD}^{+}$ & Unprimed T cells & Vogt et $\mathrm{al}^{9}$ \\
\hline & Non-naive $\mathrm{T}$ cells & $\mathrm{MNC}(\mathrm{WB})$ or $\mathrm{MLC}$ & $\mathrm{CD}^{+} \mathrm{CD}^{+} 5 \mathrm{RO}^{+}$ & $\mathrm{T}_{\text {non-naive }} / \mathrm{MNC}(\mathrm{WB})$ or MLC & Memory + effector $\mathrm{T}$ cells & Vogt et $\mathrm{al}^{9}$ \\
\hline & Non-naive T cells & $\mathrm{CD}^{+}$ & $\mathrm{CD}^{+} \mathrm{CD}^{2} 5 \mathrm{RO}^{+}$ & $\mathrm{T}_{\text {non-naive }} / \mathrm{CD}^{+}$ & Memory + effector $\mathrm{T}$ cells & Vogt et $\mathrm{al}^{9}$ \\
\hline & Central (memory) $\mathrm{T}$ cells & $\mathrm{MNC}(\mathrm{WB})$ or $\mathrm{MLC}$ & $\mathrm{CD}^{+} \mathrm{CCR}^{+} \mathrm{CD} 45 \mathrm{RO}^{+}$ & $\mathrm{T}_{\mathrm{cm}} / \mathrm{MNC}(\mathrm{WB})$ or $\mathrm{MLC}$ & Long-term immunity & Vogt et $\mathrm{al}^{9}$ \\
\hline & Central (memory) $\mathrm{T}$ cells & $\mathrm{CD}^{+}$ & $\mathrm{CD}^{+} \mathrm{CCR}^{+} \mathrm{CD}^{2} 5 \mathrm{RO}^{+}$ & $\mathrm{T}_{\mathrm{cm}} / \mathrm{CD}^{+}$ & Long-term immunity & Vogt et $\mathrm{al}^{9}$ \\
\hline & Effector (memory) T cells & $\mathrm{MNC}(\mathrm{WB})$ or $\mathrm{MLC}$ & $\mathrm{CD}^{+}{ }^{+} \mathrm{CR} 7{ }^{-} \mathrm{CD} 45 \mathrm{RO}^{+}$ & $\mathrm{T}_{\text {ems }}-\mathrm{T}_{\text {effs }} / \mathrm{MNC}(\mathrm{WB})$ or MLC & & Vogt et $\mathrm{al}^{9}$ \\
\hline & Effector (memory) $\mathrm{T}$ cells & $\mathrm{CD}^{+}$ & $\mathrm{CD}^{+}{ }^{+} \mathrm{CCR} 7 \mathrm{CD}^{-} 5 \mathrm{RO}^{+}$ & $\mathrm{T}_{\text {ems }}-\mathrm{T}_{\text {effs }} / \mathrm{CD} 3^{+}$ & & Vogt et $\mathrm{al}^{9}$ \\
\hline & Proliferating $\mathrm{T}$ cells & $\mathrm{MNC}(\mathrm{WB})$ or MLC & $\mathrm{CD}^{+}{ }^{+} \mathrm{CD} 69^{+}$ & $\mathrm{T}_{\mathrm{prol}} / \mathrm{MNC}(\mathrm{WB})$ or MLC & proliferating $\mathrm{T}$ cells & Schick et al ${ }^{10}$ \\
\hline & Proliferating $\mathrm{T}$ cells & $\mathrm{CD}^{+}$ & $\mathrm{CD}^{+} \mathrm{CD} 69^{+}$ & $\mathrm{T}_{\mathrm{prol}} / \mathrm{CD}^{+}$ & proliferating $\mathrm{T}$ cells & Schick et al ${ }^{10}$ \\
\hline & Viable $\mathrm{T}$ cells & $\mathrm{MNC}(\mathrm{WB})$ or $\mathrm{MLC}$ & $\mathrm{CD}^{+} 7 \mathrm{AAD}$ & $\mathrm{T}_{\mathrm{via}} / \mathrm{MNC}(\mathrm{WB})$ or MLC & & Schick et al ${ }^{10}$ \\
\hline & Viable T cells & $\mathrm{CD}^{+}$ & $\mathrm{CD}^{+} 7 \mathrm{AAD}$ & $\mathrm{T}_{\text {via }} / \mathrm{CD}^{+}$ & & Schick et al ${ }^{10}$ \\
\hline & TCRV $\alpha 24^{+}$-coexpressing T cells & $\mathrm{MNC}(\mathrm{WB})$ or $\mathrm{MLC}$ & $\mathrm{CD}^{+} \mathrm{V} \alpha 24^{+}$ & $\mathrm{V} \alpha 24^{+} / \mathrm{MNC}(\mathrm{WB})$ or $\mathrm{MLC}$ & V $\alpha 24$ segment joined with $J \alpha 18$ & Montoya et al ${ }^{13}$ \\
\hline & $\mathrm{TCRV} \alpha 24^{+}$-coexpressing $\mathrm{T}$ cells & $\mathrm{CD}^{+}$ & $\mathrm{CD}^{+} \mathrm{V} \alpha 24^{+}$ & $\mathrm{V} \alpha 24^{+} / \mathrm{CD}^{+}$ & $V \alpha 24$ segment joined with $J \alpha 18$ & Montoya et al ${ }^{13}$ \\
\hline & $\mathrm{CD}_{1 \mathrm{~d}^{+}}$-coexpressing $\mathrm{T}$ cells & $\mathrm{MNC}(\mathrm{WB})$ or MLC & $\mathrm{CD} 3^{+} \mathrm{CD} 1 \mathrm{~d}^{+}$ & $\mathrm{CD} \mathrm{d}^{+} / \mathrm{MNC}(\mathrm{WB})$ or $\mathrm{MLC}$ & $\mathrm{CD} \mathrm{d}^{+}$is a MHC class I-like molecule & Matsuda et al $^{51}$ \\
\hline & $\mathrm{CD} 1 \mathrm{~d}^{+}$-coexpressing $\mathrm{T}$ cells & $\mathrm{CD}^{+}$ & $\mathrm{CD}^{+} \mathrm{CD} 1 \mathrm{~d}^{+}$ & ${\mathrm{CD} 1 \mathrm{~d}^{+} / \mathrm{CD}^{+}}^{+}$ & $\mathrm{CD}_{1 \mathrm{~d}^{+}}$is a MHC class I-like molecule & Matsuda et al ${ }^{51}$ \\
\hline \multirow{3}{*}{ CIK cells } & $\mathrm{CD}^{+}{ }^{+} \mathrm{CD} 56^{+} \mathrm{CIK}$ cells & $\mathrm{MNC}(\mathrm{WB})$ or MLC & $\mathrm{CD}^{+} \mathrm{CD} 56^{+}$ & $\mathrm{CD}^{+} \mathrm{CD}^{+} 6^{+} / \mathrm{MNC}(\mathrm{WB})$ or $\mathrm{MLC}$ & Cells expressing $\mathrm{T}$ cell $(\mathrm{CD} 3)$ and & Pittari et al ${ }^{5}$ \\
\hline & $\mathrm{CD}^{+} \mathrm{CD} 161^{+} \mathrm{CIK}$ cells & $\mathrm{MNC}(\mathrm{WB})$ or MLC & $\mathrm{CD}^{+} \mathrm{CD}_{161^{+}}$ & $\mathrm{CD}^{+} \mathrm{CD} 161^{+} / \mathrm{MNC}(\mathrm{WB})$ or $\mathrm{MLC}$ & NK cell (CD56,CD161) markers & \\
\hline & $\mathrm{CD}^{+} \mathrm{CD} 161^{+} \mathrm{CIK}$ cells & $\mathrm{CD}^{+}$ & $\mathrm{CD}^{+} \mathrm{CD} 161^{+}$ & $\mathrm{CD}^{+} \mathrm{CD} 161^{+} / \mathrm{CD}^{+}$ & & \\
\hline \multirow{3}{*}{ NK cells } & $\mathrm{CD}^{-} \mathrm{CD} 56^{+} \mathrm{NK}$ cells & $\mathrm{MNC}(\mathrm{WB})$ or MLC & $\mathrm{CD}^{-} \mathrm{CD}_{5} 6^{+}$ & 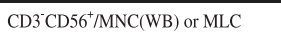 & Cells expressing NK markers (CD56, & Pittari et al ${ }^{5}$ \\
\hline & $\mathrm{CD} 3 \mathrm{CD}^{-} 161^{+} \mathrm{NK}$ cells & $\mathrm{MNC}(\mathrm{WB})$ or MLC & $\mathrm{CD}^{-} \mathrm{CD}_{161^{+}}$ & 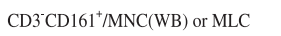 & CD161), but not expressing $\mathrm{T}$ cell & Montoya et al ${ }^{13}$ \\
\hline & $\mathrm{CD} 3{ }^{-} \mathrm{CD} 161^{+} \mathrm{NK}$ cells & $\mathrm{CD}_{161^{+}}$ & $\mathrm{CD}^{-} \mathrm{CD} 161^{+}$ & $\mathrm{CD} 3{ }^{-\mathrm{CD}} 161^{+} / \mathrm{CD} 161^{+}$ & markers (CD3) & Montoya et $\mathrm{al}^{13}$ \\
\hline \multirow{19}{*}{ iNKT cells } & $6 \mathrm{~B} 11^{+}(\mathrm{PE})$ iNKT cells & $\mathrm{MNC}(\mathrm{WB})$ or MLC & $6 \mathrm{~B} 11^{+}$ & $6 \mathrm{~B} 11^{+}(\mathrm{PE}) / \mathrm{MNC}(\mathrm{WB})$ or $\mathrm{MLC}$ & $6 \mathrm{~B} 11$ recognizes the invariant $\mathrm{CDR} 3$ & Bienemann et al ${ }^{11}$ \\
\hline & $6 \mathrm{~B} 11^{+}$(FITC) iNKT cells & $\mathrm{MNC}(\mathrm{WB})$ or MLC & $6 \mathrm{~B} 11^{+}$ & $6 \mathrm{~B} 11^{+}(\mathrm{FITC}) / \mathrm{MNC}(\mathrm{WB})$ or $\mathrm{MLC}$ & loop of the TCR $\alpha$-chain of iNKT cells & Bienemann et al ${ }^{11}$ \\
\hline & $\mathrm{CD}^{+}$coexpressing $6 \mathrm{~B} 11^{+}$iNKT cells & $\mathrm{MNC}(\mathrm{WB})$ or $\mathrm{MLC}$ & $6 \mathrm{~B} 11^{+} \mathrm{CD}^{+}$ & $6 \mathrm{~B} 11^{+} \mathrm{CD}^{+} / \mathrm{MNC}(\mathrm{WB})$ or $\mathrm{MLC}$ & $6 \mathrm{~B} 11^{+} \mathrm{CD}^{+}{ }^{+}$iNKT cells & Montoya et al ${ }^{13}$ \\
\hline & $\mathrm{CD}^{+}$coexpressing $6 \mathrm{~B} 11^{+}$iNKT cells & $\mathrm{CD}^{+}$ & $6 \mathrm{~B} 11^{+} \mathrm{CD}^{+}$ & $6 \mathrm{~B} 11^{+} \mathrm{CD}^{+} / \mathrm{CD}^{+}$ & $6 \mathrm{~B} 11^{+} \mathrm{CD}^{+}{ }^{+}$iNKT cells & Bienemann et $\mathrm{al}^{11}$ \\
\hline & $\mathrm{CD}^{+}$coexpressing $6 \mathrm{~B} 11^{+}$iNKT cells & $\mathrm{MNC}(\mathrm{WB})$ or $\mathrm{MLC}$ & $6 \mathrm{~B} 11^{+} \mathrm{CD} 4^{+}$ & $6 \mathrm{~B} 11^{+} \mathrm{CD}^{+} / \mathrm{MNC}(\mathrm{WB})$ or $\mathrm{MLC}$ & $6 \mathrm{~B} 11^{+} \mathrm{CD} 4^{+}$iNKT cells & Montoya et al ${ }^{13}$ \\
\hline & $\mathrm{CD}^{+}$coexpressing $6 \mathrm{~B} 11^{+}$iNKT cells & $\mathrm{CD}^{+}$ & $6 \mathrm{~B} 11^{+} \mathrm{CD} 4^{+}$ & $6 \mathrm{~B} 11^{+} \mathrm{CD} 4+/ \mathrm{CD} 4+$ & $6 \mathrm{~B} 11^{+} \mathrm{CD} 4^{+}$iNKT cells & Montoya et al ${ }^{13}$ \\
\hline & $\mathrm{CD} 8^{+}$coexpressing $6 \mathrm{~B} 11^{+}{ }^{+} \mathrm{NKT}$ cells & $\mathrm{MNC}(\mathrm{WB})$ or MLC & $6 \mathrm{~B} 11^{+} \mathrm{CD} 8^{+}$ & $6 \mathrm{~B} 11^{+} \mathrm{CD} 8^{+} / \mathrm{MNC}(\mathrm{WB})$ or $\mathrm{MLC}$ & $6 \mathrm{~B} 11^{+} \mathrm{CD} 8^{+}$iNKT cells & Montoya et al ${ }^{13}$ \\
\hline & $\mathrm{CD}^{+}$coexpressing $6 \mathrm{~B} 11^{+}$iNKT cells & $\mathrm{CD}^{+}$ & $6 \mathrm{~B} 11^{+} \mathrm{CD} 8^{+}$ & $6 \mathrm{~B} 11^{+} \mathrm{CD}^{+} / \mathrm{CD}^{+}$ & $6 \mathrm{~B} 11^{+} \mathrm{CD} 8^{+}$iNKT cells & Montoya et al ${ }^{13}$ \\
\hline & $\mathrm{CD}_{1 \mathrm{~d}^{+}}$coexpressing $6 \mathrm{~B} 11^{+}$iNKT cells & $\mathrm{MNC}(\mathrm{WB})$ or MLC & $6 \mathrm{~B} 11^{+} \mathrm{CD} 1 \mathrm{~d}^{+}$ & $6 \mathrm{~B} 11^{+} \mathrm{CD}^{+} \mathrm{d}^{+} / \mathrm{MNC}(\mathrm{WB})$ or $\mathrm{MLC}$ & $6 \mathrm{~B} 11^{+} \mathrm{CD} 1 \mathrm{~d}^{+}$iNKT cells & Montoya et $\mathrm{al}^{13}$ \\
\hline & $\mathrm{CD}_{1 \mathrm{~d}^{+}}$coexpressing $6 \mathrm{~B} 11^{+}$iNKT cells & $6 \mathrm{~B} 11^{+}$ & $6 \mathrm{~B} 11^{+} \mathrm{CD} 1 \mathrm{~d}^{+}$ & $6 \mathrm{~B} 11^{+} \mathrm{CD} 1 \mathrm{~d}^{+} / 6 \mathrm{~B} 11^{+}$ & $6 \mathrm{~B} 11^{+} \mathrm{CD} 1 \mathrm{~d}^{+}$iNKT cells & Montoya et al ${ }^{13}$ \\
\hline & $\mathrm{CD} 161^{+}$coexpressing $6 \mathrm{~B} 11^{+}$iNKT cells & $\mathrm{MNC}(\mathrm{WB})$ or $\mathrm{MLC}$ & $6 \mathrm{~B} 11^{+} \mathrm{CD} 161^{+}$ & $6 \mathrm{~B} 11^{+} \mathrm{CD} 161^{+} / \mathrm{MNC}(\mathrm{WB})$ or $\mathrm{MLC}$ & $6 \mathrm{~B} 11^{+} \mathrm{CD} 161^{+}$iNKT cells & Montoya et al ${ }^{13}$ \\
\hline & $\mathrm{CD} 161^{+}$coexpressing $6 \mathrm{~B} 11^{+}$iNKT cells & $6 \mathrm{~B} 11^{+}$ & $6 \mathrm{~B} 11^{+} \mathrm{CD} 161^{+}$ & $6 \mathrm{~B} 11^{+} \mathrm{CD} 161^{+} / 6 \mathrm{~B} 11^{+}$ & $6 \mathrm{~B} 11^{+} \mathrm{CD} 161^{+}$iNKT cells & Montoya et al ${ }^{13}$ \\
\hline & $\mathrm{CD}_{161^{+}}$coexpressing $6 \mathrm{~B} 11^{+}$iNKT cells & $\mathrm{CD}_{161^{+}}$ & $6 \mathrm{~B} 11^{+} \mathrm{CD} 161^{+}$ & $6 \mathrm{~B} 11^{+} \mathrm{CD} 161^{+} / \mathrm{CD} 161^{+}$ & $6 \mathrm{~B} 11^{+} \mathrm{CD} 161^{+}$iNKT cells & Montoya et al ${ }^{13}$ \\
\hline & TCRV $\alpha 24^{+}$coexpressing $6 \mathrm{~B} 11^{+}$iNKT cells & $\mathrm{MNC}(\mathrm{WB})$ or $\mathrm{MLC}$ & $6 \mathrm{~B} 11^{+} \mathrm{V} \alpha 24^{+}$ & $6 \mathrm{~B} 11^{+} \mathrm{V} \alpha 24^{+} / \mathrm{MNC}(\mathrm{WB})$ or $\mathrm{MLC}$ & $6 \mathrm{~B} 11^{+} \mathrm{V} \alpha 24^{+}$iNKT cells & Montoya et al ${ }^{13}$ \\
\hline & TCRV $\alpha 24^{+}$coexpressing $6 \mathrm{~B} 11^{+}$iNKT cells & $6 \mathrm{~B} 11^{+}$ & $6 \mathrm{~B} 11^{+} \mathrm{V} \alpha 24^{+}$ & $6 \mathrm{~B} 11^{+} \mathrm{V} \alpha 24^{+} / 6 \mathrm{~B} 11^{+}$ & $6 \mathrm{~B} 11^{+} \mathrm{V} \alpha 24^{+}$iNKT cells & Montoya et al ${ }^{13}$ \\
\hline & $\mathrm{CD} 4 \mathrm{RO}^{+}$coexpressing $6 \mathrm{~B} 11^{+}{ }^{+} \mathrm{NKT}$ cells & $\mathrm{MNC}(\mathrm{WB})$ or MLC & $6 \mathrm{~B} 11^{+} \mathrm{CD} 45 \mathrm{RO}^{+}$ & $6 \mathrm{~B} 11^{+} \mathrm{CD} 45 \mathrm{RO}^{+} / \mathrm{MNC}(\mathrm{WB})$ or $\mathrm{MLC}$ & $6 \mathrm{~B} 11^{+} \mathrm{CD} 45 \mathrm{RO}^{+}$iNKT cells & Montoya et al ${ }^{13}$ \\
\hline & $\mathrm{CD}^{2} 5 \mathrm{RO}^{+}$coexpressing $6 \mathrm{~B} 11^{+}$iNKT cells & $6 \mathrm{~B} 11^{+}$ & $6 \mathrm{~B} 11^{+} \mathrm{CD} 45 \mathrm{RO}^{+}$ & $6 \mathrm{~B} 11^{+} \mathrm{CD} 45 \mathrm{RO}^{+} / 6 \mathrm{~B} 11^{+}$ & $6 \mathrm{~B} 11^{+} \mathrm{CD} 45 \mathrm{RO}^{+}$iNKT cells & Montoya et al ${ }^{13}$ \\
\hline & $\mathrm{CD}^{2} 5 \mathrm{RO}^{-} 6 \mathrm{~B}_{11^{+}}{ }^{\mathrm{iNKT}}$ cells & $\mathrm{MNC}(\mathrm{WB})$ or MLC & $6 \mathrm{~B}^{1} 1^{+} \mathrm{CD} 45 \mathrm{RO}^{-}$ & $6 \mathrm{~B} 11^{+} \mathrm{CD} 45 \mathrm{RO} / \mathrm{MNC}(\mathrm{WB})$ or $\mathrm{MLC}$ & $6 \mathrm{~B} 11^{+} \mathrm{CD} 45 \mathrm{RO}^{-}$iNKT cells & \\
\hline & CD45RO $6 \mathrm{~B}_{1} 1^{+}$iNKT cells & $6 \mathrm{~B} 11^{+}$ & $6 \mathrm{~B}^{1} 1^{+} \mathrm{CD} 45 \mathrm{RO}^{-}$ & $6 \mathrm{~B} 11^{+} \mathrm{CD} 45 \mathrm{RO}^{-} / 6 \mathrm{~B} 11^{+}$ & $6 \mathrm{~B}_{11^{+} \mathrm{CD} 45 \mathrm{RO}^{-} \mathrm{iNKT} \text { cells }}$ & \\
\hline \multirow{5}{*}{ Blast cells } & Blast cells $\dagger$ & $\mathrm{MNC}(\mathrm{WB})$ or $\mathrm{MLC}$ & $\mathrm{bla}^{+}$ & $\mathrm{bla}^{+}$ & & \\
\hline & Blasts coexpressing CD161 & $\mathrm{MNC}(\mathrm{WB})$ or MLC & $\mathrm{bla}^{+} \mathrm{CD} 161^{+}$ & $\mathrm{bla}^{+} \mathrm{CD} 161^{+} / \mathrm{MNC}(\mathrm{WB})$ or MLC & & \\
\hline & Blasts coexpressing CD161 & $\mathrm{bla}^{+}$ & $\mathrm{bla}^{+} \mathrm{CD} 161^{+}$ & $\mathrm{bla}^{+} \mathrm{CD} 161^{+} / \mathrm{bla}^{+}$ & & \\
\hline & Blasts coexpressing 6B11 & $\mathrm{MNC}(\mathrm{WB})$ or MLC & $\mathrm{bla}^{+} 6 \mathrm{~B} 11^{+}$ & $\mathrm{bla}^{+} 6 \mathrm{~B} 11^{+} / \mathrm{MNC}(\mathrm{WB})$ or MLC & & \\
\hline & Blasts coexpressing $6 \mathrm{~B} 11$ & $\mathrm{bla}^{+}$ & $\mathrm{bla}^{+} 6 \mathrm{~B} 11^{+}$ & $\mathrm{bla}^{+} 6 \mathrm{~B} 11^{+} / \mathrm{bla}^{+}$ & & \\
\hline \multirow{6}{*}{ DC } & DC & Cells & $\mathrm{DC}^{+}(\mathrm{CD} 80, \mathrm{CD} 86, \mathrm{CD} 206)$ & $\mathrm{DC} /$ cells & $\geq 10 \% \mathrm{DC}$ in cells & Schmetzer et al 2007 \\
\hline & Leukemia derived DC & Cells & $\mathrm{DC}^{+} \mathrm{bla}^{+}$ & $\mathrm{DC}_{\mathrm{leu}} /$ cells & $\geq 5 \% \mathrm{DC}_{\text {leu }}$ in cells, $\geq 10 \% \mathrm{DC}, \geq 10 \%$ bla & Schmetzer et al 2007 \\
\hline & Blasts converted to $\mathrm{DC}_{\text {leu }}$ in blast fraction & $\mathrm{bla}^{+}$ & $\mathrm{DC}^{+} \mathrm{bla}^{+}$ & $\mathrm{DC}_{\mathrm{leu}} / \mathrm{bla}^{+}$ & $\geq 5 \% \mathrm{DC}_{\text {leu }}$ in cells, $\geq 10 \% \mathrm{DC}, \geq 10 \%$ bla & Schmetzer et al 2007 \\
\hline & $\mathrm{DC}_{\text {leu }}$ in $\mathrm{DC}$ fraction & $\mathrm{DC}$ & $\mathrm{DC}^{+} \mathrm{bla}^{+}$ & $\mathrm{DC}_{\mathrm{leu}} / \mathrm{DC}$ & $\geq 5 \% \mathrm{DC}_{\text {leu }}$ in cells, $\geq 10 \% \mathrm{DC}, \geq 10 \%$ bla & Schmetzer et al 2007 \\
\hline & Migratory mature DC in DC fraction & Cells & $\mathrm{DC}^{+} \mathrm{CCR} 7^{+}$ & $\mathrm{DC}_{\mathrm{mig}} / \mathrm{DC}$ & $\geq 10 \% \mathrm{DC}$ in cells & Grabrucker et al 2010 \\
\hline & Viable DC in DC-fraction & Cells & $\mathrm{DC}^{+} 7 \mathrm{AAD}^{-}$ & $\mathrm{DC}_{\mathrm{via}} / \mathrm{DC}$ & $\geq 10 \% \mathrm{DC}$ in cells & Grabrucker et al 2010 \\
\hline
\end{tabular}

Surface marker combinations as well as T/iNKT/NK/CIK cell and DC subtypes after flow cytometric staining with fluorochrome-labeled antibodies are given.

*Total proportions of cell subsets in uncultured MNC/WB or in MLC (after culture with T cells and IL-2).

$\dagger$ Cells expressing blast markers: patients' individually selected blast-markers with the highest expression (Table 2: blast phenotype).

CIK indicates cytokine-induced killer; DC, dendritic cells; iNKT, invariant natural killer T; NK, natural killer; MLC, mixed lymphocyte cultures; MNC, mononuclear cells; WB, whole blood. 
Ludwigs-Maximilians-University Hospital in Munich; Vote-No 339-05). The mean age of AML patients was 50 (range: 23-81) years, of ALL patients 22 (range: 3-50) years and of CLL patients 57 (range: 33-72) years. The female to male ratio of AML patients was 1:1.9, of ALL patients was 1:1.7, and of CLL patients was 1:0.9 (Table 2A).

Diagnosis and classification of AML patients was based on the "French American British" classification: minimally differentiated AML (M0: $n=1)$, AML without maturation (M1: $\mathrm{n}=6$ ), AML with granulocytic maturation (M2: $\mathrm{n}=6$ ), acute myelomonocytic leukemia (M4: $\mathrm{n}=4$ ), acute myelomonocytic leukemia together with BM eosinophilia (M4eo: $\mathrm{n}=2$ ), acute monocytic leukemia (M5: $\mathrm{n}=3)$. Patients presented with primary AML $(\mathrm{n}=18)$ or with secondary AML $(n=5)$. Patients stages were: first diagnosis $(n=20)$, relapse before $(n=1)$ or after SCT $(\mathrm{n}=2)$. Patients were classified in cytogenetic risk groups based on the National Comprehensive Cancer Network $(\mathrm{NCCN})$ guidelines as "favorable" $(\mathrm{n}=3)$, "intermediate" $(n=11)$, or "adverse risk" $(n=4)$; for 5 patients no further data were available.

The subtypes of the 19 ALL patients were immune cytologically classified according to the European Group of Immunophenotyping of Leukemias classification: pro B-ALL (BI: $\mathrm{n}=1$ ), c ALL (BII: $\mathrm{n}=5$ ), pre B-ALL (BIII: $\mathrm{n}=2), \mathrm{My}^{+} \mathrm{c}$ ALL $(\mathrm{BII}+\mathrm{My}: \mathrm{n}=3), \mathrm{My}^{+}$pre B-ALL $(\mathrm{BIII}+\mathrm{My}: \mathrm{n}=1)$, pro T-ALL $(\mathrm{TI}: \mathrm{n}=1)$, pre T-ALL (TII: $\mathrm{n}=1$ ), cortical T ALL (TIII: $\mathrm{n}=4$ ), mature T ALL $(T I V: n=1)$. Patients presented with primary ALL $(n=5)$ or with secondary ALL $(n=14)$. Stages of samples were: diagnosis before SCT $(n=17)$ or at relapse after SCT $(n=2)$. Risk stratification of adult ALL was based on the Study Group for Adult Acute Lymphoblastic Leukemia (GMALL) as "standard" $(\mathrm{n}=3)$, "high" $(\mathrm{n}=1)$ or "highest risk" ( $n=3)$; for 12 patients no further data were available.

All CLL patients were classified as pB-CLL $(n=21)$ at diagnosis $(n=2)$ or with persisting disease $(n=19)$. Risk stratification was based on the Binet-classification: Binet A $(n=14)$, Binet B $(n=6)$ or Binet C $(n=1)$.

\section{Cell Lines Included for Surface Marker Analyses}

The following cell lines were studied for surface marker profiles: HL-60 (AML-M2), OCI-AML2 (AMLM4), Mono-Mac 6 (AML-M5), THP-1 (AML-M5), MOLM (AML-M5a), RAMOS (B-ALL-L3), RAJI (BALL-L3) and JURKAT (T-ALL). Cell lines were purchased from the American Type Culture Collection and were cultured according to the manufacturer's instructions (Table 2A).

\section{AML Patients and Samples Included for Culture Experiments}

Cellular composition of immune reactive cells in MNC or WB samples from 5 AML patients, 1 myelodysplastic syndrome (MDS) patient and from 10 healthy volunteers were studied before or after culture with/without $\mathrm{DC} / \mathrm{DC}_{\mathrm{leu}}{ }^{-}$ generating strategies or mixed lymphocyte culture (MLC) with $(\mathrm{T})$ cells from the patients. Details about patient and sample characteristics are given in Table $2 \mathrm{~B}$.

Cell cultures were either performed under "normoxic conditions" $\left(37^{\circ} \mathrm{C}, 5 \% \mathrm{CO}_{2}\right.$ and $\left.21 \% \mathrm{O}_{2}\right)$. Further we studied the influence of hypoxia on the composition and function of different immune reactive cells and cultured samples in parallel under "hypoxic conditions" $\left(37^{\circ} \mathrm{C}, 5 \%\right.$
$\mathrm{CO}_{2}$ and with either varying $\mathrm{O}_{2}$-concentrations between $0 \%$ and $17 \%$ during the incubation time in some cases or with a defined $\mathrm{O}_{2}$-concentration of $6 \%$ or $10 \%$ ) using an InVivo400 working station (Ruskinn Technology, Bridgend, United Kingdom).

\section{Generation From Isolated MNC or WB}

$\mathrm{DC} / \mathrm{DC}_{\text {leu }}$ were generated from 4 to $5 \times 10^{6}$ isolated MNC from healthy volunteers or AML/MDS patients in blast-rich stages of the disease as described previously by others or us ${ }^{19,27}$ using Kit-D, Picibanil 1 "(Pici1)" or "Pici2" (Table 3) (D.C. Amberger, personal written communication). Therefore, cells were pipetted into 12-multiwell tissue culture plates (ThermoFisher Scientific, Darmstadt, Germany) and were diluted in $2 \mathrm{~mL}$ serum-free X-Vivo15-medium (Lonza, Basel, Swiss).

Moreover, $\mathrm{DC} / \mathrm{DC}_{\mathrm{leu}}$ were generated from WB (presenting the physiological cellular and soluble composition of the individual samples) obtained from AML/MDS patients in blast-rich stages of the disease or from healthy volunteers. $^{20,29}$ A total of $500 \mu \mathrm{L}$ WB was pipetted in 12-multiwell plates and diluted 1:2 in X-Vivo15-medium to imitate the physiological conditions. DC were generated from WB using 6 different DC-generating methods: "Pici1," "Pici2," Kit-D, Kit-I, Kit-K, and Kit-M (Table 3). A patent was written to save the idea of Kit-compositions (102014014993.5, German Patent Office), but no financial conflicts of interest have to be declared. In the subsequent chapters we summarize all DC-generating methods and Kits under the term "cocktails." WB/MNC cultures without added response modifiers severed as a control. All substances used for the DC generation are approved for human treatment.

DC-subtypes were quantified as described in the chapter "Cell-characterization by flow cytometry". ${ }^{19,20,29}$

\section{"Pici1"}

DC were generated from $\mathrm{MNC}$ or WB with the DCgenerating protocol "Picil" containing $500 \mathrm{U} / \mathrm{mL}$ granulocyte macrophage colony-stimulating factor (GM-CSF, Sanofi-Aventis, Frankfurt, Germany) and $250 \mathrm{U} / \mathrm{mL}$ interleukin 4 (IL-4) (PeproTech, Berlin, Germany). After 6-7 days, $10 \mu \mathrm{g} / \mathrm{mL}$ Picibanil (OK 432) - a lysis product from Streptococcus pyogenes which has unspecific immune modulatory effects (Chugai Pharmaceutical Co., Kajiwara, Japan) and $1 \mu \mathrm{g} / \mathrm{mL}$ prostaglandin $\mathrm{E}_{2}\left(\mathrm{PGE}_{2}\right)$ (PeproTech) were added. ${ }^{19,28}$ After 7-10 days of incubation cells were harvested and used for further experiments.

\section{"Pici2"}

DC were generated from MNC or WB with the "Pici2"-DC-generating protocol-a protocol developed by our group, with the same composition as given above for "Picil," however substituting $\mathrm{PGE}_{2}$ by $\mathrm{PGE}_{1}$ (PeproTech; D.C. Amberger, personal communication).

\section{Kit-D}

The generation of DC from MNC or WB with Kit-D was performed using $800 \mathrm{U} / \mathrm{mL}$ GM-CSF, $10 \mu \mathrm{g} / \mathrm{mL}$ Picibanil and $1 \mu \mathrm{g} / \mathrm{mL} \mathrm{PGE}_{2} \cdot{ }^{20}$ After $2-3$ days the same amounts of cytokines were added and after 7-10 days of incubation cells were harvested and used for subsequent experiments. 
TABLE 2. Patients' and Cell-lines' Characteristics are Presented

\begin{tabular}{|c|c|c|c|c|c|c|c|c|c|c|}
\hline \multicolumn{3}{|c|}{ (A) Uncultured AML, ALL, CLL Samples and Cellines Studied } & & Cell & & & & Risk score & Resp. to & Resp. to Induction Chemotherapy \\
\hline Pat.\# & Dgn./Sex & Subtype & Stage & Source & Blast Phenotype (CD) & Blasts \% & Cytogenetic Marker at Dgn. & $(\mathrm{NCCN})$ & SCT1 & (CLL: need for initial therapy) \\
\hline P1050 & $32 / \mathrm{F}$ & $\mathrm{s} / \mathrm{M} 1$ & Dgn. & PB & $117,33,13$ & 78 & $46, \mathrm{XX}$ & ND & $\mathrm{CR}$ & ND \\
\hline P1053 & 25/M & $\mathrm{p} / \mathrm{M} 1$ & Rez. & $\mathrm{PB}$ & $117,34,33,56$ & 65 & ND & ND & NCR & ND \\
\hline P1056 & $27 / M$ & $\mathrm{p} / \mathrm{M} 4$ & Dgn. & $\mathrm{PB}$ & $\mathbf{1 1 7 , 3 4 , 3 3 , 1 3 , 1 5}$ & 53 & $46, X Y$ & ND & ND & CR \\
\hline P1057 & $32 / \mathrm{M}$ & $\mathrm{p} / \mathrm{M} 5$ & Dgn. & $\mathrm{PB}$ & $\mathbf{1 1 7}, 34,33,13,14,15,38,2$ & 39 & $\operatorname{inv}(16) \mathrm{pq},+22$ & Favorable & ND & $\mathrm{ND}$ \\
\hline P1058 & $71 / \mathrm{M}$ & $\mathrm{p} / \mathrm{M} 1$ & Dgn. & $\mathrm{PB}$ & 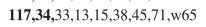 & 91 & +11 & Intermediate & ND & ND \\
\hline P1059 & $66 / \mathrm{M}$ & $\mathrm{p} / \mathrm{M} 4$ & Dgn. & $\mathrm{PB}$ & $117,34,33,13,7$ & 84 & $\operatorname{del}(5) \mathrm{qq}, \operatorname{add}(17) \mathrm{p}, \operatorname{add}(21) \mathrm{q}, \operatorname{der}(9)$ & Adverse & ND & CR \\
\hline P1060 & $81 / \mathrm{F}$ & s/n.d. & Dgn. & $\mathrm{PB}$ & $117,34,33,13$ & 97 & ND & $\mathrm{ND}$ & ND & ND \\
\hline P1061 & $62 / \mathrm{F}$ & $\mathrm{p} / \mathrm{M} 0$ & Rel. a. SCT & $\mathrm{PB}$ & $117,34,33,13$ & 96 & $46, \mathrm{XX}$ & Intermediate & NCR & ND \\
\hline P1062 & $41 / \mathrm{F}$ & $\mathrm{p} / \mathrm{M} 4$ & Dgn. & $\mathrm{PB}$ & $\mathbf{1 1 7}, \mathbf{3 4}, 33,13,14,15,71$ & 61 & $\mathrm{t}(6 ; 9) \mathrm{pq}, \operatorname{add}(21),-7, \operatorname{del}(8), \operatorname{del}(15),+\operatorname{mar}$ & Adverse & ND & NCR \\
\hline P1063 & $26 / \mathrm{M}$ & $\mathrm{p} / \mathrm{M} 5$ & Rel. a. SCT & $\mathrm{PB}$ & $117,34,2$ & 86 & ND & ND & ND & ND \\
\hline P1066 & $60 / \mathrm{M}$ & $\mathrm{s} / \mathrm{M} 2$ & Dgn. & $\mathrm{PB}$ & $117,34,33,65$ & 74 & $46, X Y$ & Adverse & ND & ND \\
\hline AML P1067 & $27 / \mathrm{M}$ & $\mathrm{p} / \mathrm{M} 4 \mathrm{eo}$ & Dgn. & $\mathrm{PB}$ & $\mathbf{1 1 7 , 3 4 , 3 3 , 1 3 , 1 5 , 6 5}$ & 41 & $\operatorname{inv}(16) \mathrm{pq},+8$ & Favorable & ND & CR \\
\hline P1068 & $76 / \mathrm{M}$ & $\mathrm{p} / \mathrm{M} 2$ & Dgn. & $\mathrm{PB}$ & $117,34,33,13$ & 39 & ND & Intermediate & ND & ND \\
\hline P1069 & $33 / \mathrm{M}$ & $\mathrm{p} / \mathrm{M} 4 \mathrm{eo}$ & Dgn. & $\mathrm{PB}$ & $117,34,33,13,15$ & 61 & $\operatorname{inv}(16) \mathrm{pq}, \mathrm{t}(12 ; 17) \mathrm{pq}$ & Favorable & ND & $\mathrm{CR}$ \\
\hline P1071 & $71 / \mathrm{F}$ & $\mathrm{s} / \mathrm{M} 1$ & Dgn. & $\mathrm{PB}$ & $117,34,33,13,15$ & 60 & +4 & Intermediate & ND & $\mathrm{CR}$ \\
\hline P1072 & $58 / \mathrm{M}$ & $\mathrm{p} / \mathrm{M} 2$ & Pers. & $\mathrm{PB}$ & $117,34,33,13$ & 70 & $-4,-5,-7,-11,-12,-14,-16,-21,+\operatorname{mar}$ & Adverse & ND & NCR \\
\hline P1073 & $23 / \mathrm{M}$ & $\mathrm{p} / \mathrm{M} 5$ & Dgn. & $\mathrm{PB}$ & $117,34,33,13,15,7,65$ & 18 & $+8,+13$ & Intermediate & ND & ND \\
\hline P1076 & $47 / \mathrm{F}$ & s/M1 & Dgn. & $\mathrm{PB}$ & $117,34,33,13,14$ & 99 & +8 & Intermediate & CR & CR \\
\hline P1077 & $41 / \mathrm{F}$ & $\mathrm{p} / \mathrm{M} 1$ & Dgn. & $\mathrm{PB}$ & $117,34,33,13,15,7$ & 71 & $\operatorname{del}(12) \mathrm{p}$ & Intermediate & CR & $\mathrm{CR}$ \\
\hline P1078 & $73 / \mathrm{M}$ & $\mathrm{p} / \mathrm{M} 2$ & Dgn. & $\mathrm{PB}$ & 117.34 & 84 & $46, X Y$ & Intermediate & ND & ND \\
\hline P1083 & $41 / \mathrm{M}$ & $\mathrm{p} / \mathrm{M} 2$ & Dgn. & $\mathrm{PB}$ & $117,133,33,13,65$ & 43 & $46, X Y$ & Intermediate & CR & CR \\
\hline P1084 & $55 / \mathrm{M}$ & $\mathrm{p} / \mathrm{M} 4$ & Dgn. & $\mathrm{PB}$ & $117,33,13,71$ & 84 & $46 . X Y$ & Intermediate & ND & CR \\
\hline P1085 & $71 / \mathrm{F}$ & $\mathrm{p} / \mathrm{M} 2$ & Dgn. & $\mathrm{PB}$ & $117,33,56$ & 96 & $46, \mathrm{XX}$ & Intermediate & ND & ND \\
\hline P1106 & $24 / \mathrm{F}$ & $\mathrm{p} / \mathrm{BII}+\mathrm{My}$ & Dgn. & PB & $34,19,33,133,13$ & 81 & $46, \mathrm{XX}$ & High risk & ND & $\mathrm{CR}$ \\
\hline P1107 & $31 / M$ & $\mathrm{~s} / \mathrm{BII}+\mathrm{My}$ & Dgn. & $\mathrm{PB}$ & $\mathbf{3 4 , 1 9 , 3 3 , 1 0 , 2 4}$ & 36 & $\mathrm{t}(9 ; 11) \mathrm{qq}$ & Highest risk & ND & CR \\
\hline P1108 & $32 / \mathrm{M}$ & s/TIII & Dgn. & $\mathrm{PB}$ & $5,2,1 \mathrm{a}, 15, \mathrm{cy} 3$ & 98 & $46, X Y$ & Standard & ND & $\mathrm{CR}$ \\
\hline P1109 & $21 / \mathrm{M}$ & $\mathrm{p} / \mathrm{BII}+\mathrm{My}$ & Dgn. & $\mathrm{PB}$ & $\mathbf{3 4}, 19,33,13,10,38$ & 85 & $46, X Y$ & Standard & ND & $\mathrm{CR}$ \\
\hline P1110 & $50 / \mathrm{F}$ & $\mathrm{p} / \mathrm{BIII}+\mathrm{My}$ & Dgn. & $\mathrm{PB}$ & $34,133,33$ & 59 & $\mathrm{t}(9 ; 22) \mathrm{qq}, \operatorname{der}(22)$ & highest risk & ND & $\mathrm{CR}$ \\
\hline P1111 & $26 / \mathrm{M}$ & $\mathrm{s} / \mathrm{BII}$ & Rel. a. SCT & $\mathrm{PB}$ & $34,19,10$ & 64 & $\operatorname{del}(11 \mathrm{q})$ & ND & ND & ND \\
\hline P1112 & $37 / M$ & $\mathrm{~s} / \mathrm{BII}$ & Rel. a. SCT & $\mathrm{PB}$ & $\mathbf{3 4 , 1 9 , 1 0}$ & 17 & ND & $\mathrm{ND}$ & ND & ND \\
\hline P1113 & $64 / \mathrm{F}$ & B B & Rez/pers. & $\mathrm{PB}$ & $34,19,15$ & & ND & ND & ND & ND \\
\hline P1114 & $22 / \mathrm{M}$ & $\mathrm{p} / \mathrm{BIII}$ & Dgn. & $\mathrm{PB}$ & $19,20,34,38$ & 97 & $46, X Y$ & Highest risk & ND & $\mathrm{CR}$ \\
\hline ALL P1115 & $45 / M$ & $\mathrm{p} / \mathrm{TIII}$ & Dgn. & $\mathrm{PB}$ & $5,7,38,71$ & 99 & $46, X Y$ & Standard & ND & $\mathrm{CR}$ \\
\hline P1120 & $20 / M$ & $\begin{array}{l}\mathrm{s} / \mathrm{TII} \\
\mathrm{s}\end{array}$ & Dgn. & PB & $\mathbf{1 9 , 5}, 34,20,3$ & 28 & $46, X Y$ & ND & CR & ND \\
\hline P1121 & $25 / \mathrm{F}$ & $\mathrm{s} / \mathrm{BI}$ & Dgn. & $\mathrm{PB}$ & $\mathbf{3 4 , 1 9}, 33$ & 32 & ND & ND & ND & ND \\
\hline P1122 & $23 / \mathrm{M}$ & s/TIII & Dgn. & $\mathrm{PB}$ & $4,8,1,2,5,7$ & 86 & $46, X Y$ & & & \\
\hline P1129 & $11 / \mathrm{M}$ & s/BII & Dgn. & BM & $\mathbf{3 4 , 1 9 , 1 0 , 2 2}$ & 85 & $46, X Y$ & $\mathrm{ND}$ & ND & CR \\
\hline P1132 & $12 / \mathrm{M}$ & $\mathrm{s} / \mathrm{BIII}$ & Dgn. & BM & $19,10,22$ & 84 & ND & $\mathrm{ND}$ & ND & $\mathrm{CR}$ \\
\hline P1133 & $3 / \mathrm{F}$ & $\begin{array}{l}\text { s/BII } \\
s / 3\end{array}$ & Dgn. & BM & $\mathbf{3 4 , 1 9 , 1 0 , 2 2}$ & 55 & $46, X X$ & ND & ND & $\mathrm{CR}$ \\
\hline P1135 & $17 / \mathrm{M}$ & $s / T I$ & Dgn. & BM & $\mathbf{3 4}, 7,4,5,10,13,33$ & 98 & $46, X Y$ & ND & ND & $\mathrm{CR}$ \\
\hline P1136 & $5 / \mathrm{F}$ & s/TIII & Dgn. & $\mathrm{PB}$ & $\mathbf{3 4 , 7 , 1 \mathrm { a } , 2 , 3 , 5 , 1 0}$ & 82 & $46, x x$ & ND & ND & CR \\
\hline P1137 & $3 / \mathrm{F}$ & $\mathrm{s} / \mathrm{BII}$ & Dgn. & BM & $\mathbf{3 4}, \mathbf{1 0}, 19,22$ & 71 & $46, \mathrm{XX}$ & $\mathrm{ND}$ & ND & $\mathrm{CR}$ \\
\hline P1146 & $8 / \mathrm{F}$ & $\mathrm{s} / \mathrm{TTV}$ & Dgn. & $\mathrm{PB}$ & $7,3,1,34$ & 98 & $46, X X$ & $\mathrm{ND}$ & ND & $\mathrm{CR}$ \\
\hline $\begin{array}{ll}\text { P1088 } \\
\end{array}$ & $44 / \mathrm{F}$ & $\mathrm{p} / \mathrm{B}-\mathrm{CLL}$ & Pers. & $\mathrm{PB}$ & $5,19,20$ & 98 & ND & $\mathbf{A}$ & ND & Yes \\
\hline P1089 & $54 / \mathrm{M}$ & $\mathrm{p} / \mathrm{B}-\mathrm{CLL}$ & Pers. & $\mathrm{PB}$ & 5.19 & 95 & ND & B & ND & Yes \\
\hline P1090 & $43 / \mathrm{M}$ & $\mathrm{p} / \mathrm{B}-\mathrm{CLL}$ & Dgn. & $\mathrm{PB}$ & 5,19 ,kappa & 95 & $\operatorname{add}(1) \mathrm{q} \cdot \operatorname{del}(9) \mathrm{q}, \operatorname{del}(11) \mathrm{qq}$ & $\mathbf{A}$ & ND & Yes \\
\hline P1091 & $68 / M$ & $\mathrm{p} / \mathrm{B}-\mathrm{CLL}$ & Pers. & $\mathrm{PB}$ & $5,19,20$ & 96 & $\operatorname{del}(13) \mathrm{q}$ & A & ND & No \\
\hline P1092 & $66 / \mathrm{M}$ & $\mathrm{p} / \mathrm{B}-\mathrm{CLL}$ & Pers. & $\mathrm{PB}$ & $5,19,20$ & 71 & ND & B & ND & No \\
\hline P1093 & $51 / \mathrm{F}$ & $\mathrm{p} / \mathrm{B}-\mathrm{CLL}$ & Pers. & $\mathrm{PB}$ & 5,23, kappa & 94 & ND & A & ND & No \\
\hline P1094 & $67 / M$ & $\mathrm{p} / \mathrm{B}-\mathrm{CLL}$ & Pers. & $\mathrm{PB}$ & 5,19, kappa & 91 & ND & $\mathrm{A}$ & ND & No \\
\hline P1095 & $65 / \mathrm{F}$ & $\mathrm{p} / \mathrm{B}-\mathrm{CLL}$ & Pers. & $\mathrm{PB}$ & 5.19 & 88 & $\operatorname{del}(13) \mathrm{q}$ & A & ND & Yes \\
\hline P1096 & $64 / \mathrm{M}$ & $\mathrm{p} / \mathrm{B}-\mathrm{CLL}$ & Pers. & $\mathrm{PB}$ & 5,19, lambda & 95 & ND & $\mathbf{A}$ & ND & No \\
\hline P1097 & $72 / \mathrm{F}$ & $\mathrm{p} / \mathrm{B}-\mathrm{CLL}$ & Pers. & PB & $5,19,20,22$, kappa & 97 & ND & $\mathbf{A}$ & ND & Yes \\
\hline CLL P1098 & $60 / \mathrm{F}$ & $\mathrm{p} / \mathrm{B}-\mathrm{CLL}$ & Pers. & $\mathrm{PB}$ & 5,19, kappa & 93 & ND & B & ND & No \\
\hline P1099 & $67 / \mathrm{M}$ & $\mathrm{p} / \mathrm{B}-\mathrm{CLL}$ & Dgn. & $\mathrm{PB}$ & 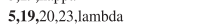 & 89 & ND & $\mathbf{A}$ & ND & No \\
\hline P1100 & $36 / \mathrm{M}$ & $\mathrm{p} / \mathrm{B}-\mathrm{CLL}$ & Pers. & $\mathrm{PB}$ & 5,19 ,lambda & 91 & $\operatorname{del}(17) \mathrm{p}, \operatorname{der}(11) \mathrm{q}$ & B & ND & Yes \\
\hline P1101 & $52 / \mathrm{M}$ & $\mathrm{p} / \mathrm{B}-\mathrm{CLL}$ & Pers. & $\mathrm{PB}$ & $5,19,20$ & 96 & ND & $\mathbf{A}$ & ND & Yes \\
\hline P1102 & $45 / \mathrm{F}$ & $\mathrm{p} / \mathrm{B}-\mathrm{CLL}$ & Pers. & $\mathrm{PB}$ & 5.19 & 91 & $\operatorname{del}(13) \mathrm{q}$ & $\mathbf{A}$ & ND & Yes \\
\hline P1103 & $67 / \mathrm{F}$ & $\mathrm{p} / \mathrm{B}-\mathrm{CLL}$ & Pers. & $\mathrm{PB}$ & $\mathbf{5 , 1 9 , 2 0}$ & 87 & $\operatorname{del}(17) \mathrm{q}$ & $\mathbf{A}$ & ND & Yes \\
\hline P1104 & $66 / \mathrm{F}$ & $\mathrm{p} / \mathrm{B}-\mathrm{CLL}$ & Pers. & $\mathrm{PB}$ & 5,19 ,kappa & 94 & ND & $\mathbf{A}$ & ND & Yes \\
\hline P1116 & 66/F & $\mathrm{p} / \mathrm{B}-\mathrm{CLL}$ & Pers. & $\mathrm{PB}$ & 5,19, kappa & 96 & $\mathrm{t}(8 ; 13) \mathrm{qq}$ & A & ND & Yes \\
\hline P1117 & $33 / M$ & $\mathrm{p} / \mathrm{B}-\mathrm{CLL}$ & Pers. & $\mathrm{PB}$ & 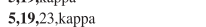 & 40 & $\operatorname{del}(13) \mathrm{q}$ & B & ND & Yes \\
\hline P1118 & $60 / \mathrm{F}$ & $\mathrm{p} / \mathrm{B}-\mathrm{CLL}$ & Pers. & $\mathrm{PB}$ & $\mathbf{5 , 1 9 , 2 0 , 2 2 , 2 3 , \text { kappa }}$ & 32 & $\operatorname{del}(11) q$ & $\mathrm{C}$ & ND & Yes \\
\hline P1119 & $55 / \mathrm{F}$ & $\mathrm{p} / \mathrm{B}-\mathrm{CLL}$ & Pers. & $\mathrm{PB}$ & $\mathbf{5 , 1 9 , 2 0 , 2 2 , 2 3 , 3 8 , \text { kappa }}$ & 57 & $\mathrm{ND}$ & B & CR & Yes \\
\hline Celllines and their & origin & & & & & & & & & \\
\hline & Age & & & Cell & & & & & & \\
\hline Name & /Sex & Subtype & Cell type & Source & Blast phenotype (CD) & & & & & \\
\hline HL-60 & $35 / \mathrm{F}$ & FAB M2 & AML & $\mathrm{PB}$ & $\mathbf{3 3 , 1 3 , 1 5}$ & & & & & \\
\hline OCI-AML2 & $65 / \mathrm{M}$ & FAB M4 & AML & $\mathrm{PB}$ & $13,14,15,33,4$ & & & & & \\
\hline THP.1 & $1 / \mathrm{M}$ & FAB M5 & AML & $\mathrm{PB}$ & $33,13,14,15$ & & & & & \\
\hline Mono-Mac-6 & $664 / \mathrm{M}$ & FAB M5 & AML & $\mathrm{PB}$ & $\mathbf{1 3}, 14,15,33,68$ & & & & & \\
\hline MOLM-13 & $20 / \mathrm{M}$ & FAB M5a & AML & $\mathrm{PB}$ & $\mathbf{3 3}, 13,15,4$ & & & & & \\
\hline RAMOS & $3 / \mathrm{M}$ & B-lymphoblastic & Burkitt lymphoma & Ascitic fl & $\mathrm{d} 19,10,20,37,38,80$ & & & & & \\
\hline RAJI & $11 / \mathrm{M}$ & B-lymphoblastic & Burkitt lymphoma & Left max & a 20,10,13,19,37 & & & & & \\
\hline JURKAT & $14 / \mathrm{M}$ & my $y^{\top} T$-linear & $\begin{array}{l}\text { T-ALL } \\
\end{array}$ & $\mathrm{ND}$ & $33,13,2,3,4,5,6,7,34$ & & & & & \\
\hline (B) AML-samples u & used for $\mathrm{cu}$ & ulture experiments & in hypoxia vs. normo & 1oxia & & & & & & \\
\hline & Age at & Subtype & & Cell & & & & & & \\
\hline Pat. \# & dgn./sex & $(\mathbf{F A B})$ & Stage & Source & Blast phenotype & Blasts \% & Cytogenetic marker at dgn. & & & \\
\hline P1424 & $37 / \mathrm{F}$ & $\mathrm{p} / \mathrm{M} 4$ & Rez. & $\mathrm{PB}$ & $117,13,33,45$ & 30 & $46 . \mathrm{XX}$ & & & \\
\hline P1426 & $61 / \mathrm{F}$ & $\mathrm{p} / \mathrm{M} 5$ & Dgn. & $\mathrm{PB}$ & $\mathbf{3 4}, 117,13,33,64$ & 40 & ND & & & \\
\hline AML P1430 & $79 / \mathrm{M}$ & p/M5/M6 & Dgn. & $\mathrm{PB}$ & $34,13,33,117$ & 70 & $46, X Y$ & & & \\
\hline P1433 & $59 / \mathrm{M}$ & p/MDS (RAEB-II) & Dgn. & $\mathrm{PB}$ & $\mathbf{3 4 , 1 3 , 1 5}$ & 18 & ND & & & \\
\hline P1434 & $61 / \mathrm{F}$ & $\mathrm{s} / \mathrm{ND}$ & Dgn. & $\mathrm{PB}$ & $\mathbf{3 4 , 1 1 7 , 6 4 , 5 6 , 3 3 , 1 3 , 7}$ & 61 & $46, X X, t(3 ; 8)$ & & & \\
\hline P1439 & $61 / \mathrm{F}$ & s/M5 & Dgn. & $\mathrm{PB}$ & $34,117,13,33$ & 9 & inv(16) & & & \\
\hline
\end{tabular}

AML/ALL/CLL subtypes, age, sex, stages of the disease, proportions of blasts, blast phenotypes evaluated by flow cytometry are given ${ }^{1}$ Complete remission (CR) achieved or not achieved (NCR) after treatment with SCT.

Bold letters antibodies used for (co)expression analyses.

ALL indicates acute lymphoid leukemia; AML, acute myeloid leukemia; BM, bone marrow; CIK, cytokine-induced killer; CLL, chronic lymphoid leukemia; Dgn., first diagnosis; F, female; FAB, French American British classification; iNKT, invariant natural killer T; M, male; NCCN, National Comprehensive Cancer Network; ND, no data; NK, natural killer; Pat.\#, patient's number; PB, peripheral blood; Pers., persisting disease; Rel., relapse; Rel.a.SCT, relapse after stem cell transplantation. 


\begin{tabular}{|c|c|c|c|}
\hline “Cocktails" & Composition & Mode of Action & $\begin{array}{c}\text { Culture } \\
\text { Time (d) }\end{array}$ \\
\hline \multirow[t]{2}{*}{$\begin{array}{l}\text { "Picibanil 1" } \\
\text { (Pici1) }\end{array}$} & GM-CSF & $\begin{array}{l}\text { GM-CSF: induction of } \\
\text { myeloid (DC) } \\
\text { differentiation }\end{array}$ & $7-10$ \\
\hline & $\begin{array}{l}\text { IL-4 } \\
\text { OK-432 } \\
\text { PGE }_{2}\end{array}$ & & \\
\hline \multirow[t]{2}{*}{$\begin{array}{l}\text { "Picibanil 2" } \\
\text { (Pici2)* }\end{array}$} & $\begin{array}{c}\text { GM-CSF } \\
\text { IL-4 } \\
\text { OK-432 } \\
\text { PGE }_{1}\end{array}$ & $\begin{array}{l}\text { IL-4: induction of } \\
\text { DC-differentiation }\end{array}$ & $7-10$ \\
\hline & & $\begin{array}{l}\text { Picibanil (OK-432): lysis } \\
\text { product from } \\
\text { Streptococcus pyogenes; } \\
\text { stimulates } \\
\text { DC-differentiation }\end{array}$ & \\
\hline Kit-D & $\begin{array}{l}\text { GM-CSF } \\
\text { OK-432 } \\
\mathrm{PGE}_{2}\end{array}$ & & $7-10$ \\
\hline Kit-I & GM-CSF & $\begin{array}{l}\mathrm{PGE}_{2} \text { : increases CCR7- } \\
\text { expression and enhances } \\
\text { migration }\end{array}$ & $7-10$ \\
\hline Kit-K & $\begin{array}{l}\text { OK-432 } \\
\text { GM-CSF } \\
\text { PGE }_{2}\end{array}$ & & $7-10$ \\
\hline Kit-M & $\begin{array}{c}\text { GM-CSF } \\
\text { PGE }_{1}\end{array}$ & $\begin{array}{c}\mathrm{PGE}_{1} \text { : effects are } \\
\text { comparable with } \mathrm{PGE}_{2}\end{array}$ & $7-10$ \\
\hline
\end{tabular}

*Personal communication D.C. Amberger

DC indicates dendritic cells; GM-CSF, granulocyte macrophage colonystimulating factor; IL-4, interleukin 4; OK-432, Picibanil; $\mathrm{PGE}_{1}$, prostaglandin $\mathrm{E}_{1} ; \mathrm{PGE}_{2}$, prostaglandin $\mathrm{E}_{2}$.

\section{Kit-I}

DC were generated with Kit-I using $800 \mathrm{U} / \mathrm{mL}$ GM-CSF and $10 \mu \mathrm{g} / \mathrm{mL}$ Picibanil. ${ }^{20}$ Incubations were performed in analogy to Kit-D.

\section{Kit-K}

Kit-K consisted of $800 \mathrm{U} / \mathrm{mL}$ GM-CSF and $1 \mu \mathrm{g} / \mathrm{mL}$ $\mathrm{PGE}_{2}{ }^{20}$ Incubations were performed in analogy to Kit-D.

\section{Kit-M}

For the generation of DC with Kit-M, $800 \mathrm{U} / \mathrm{mL}$ GM$\mathrm{CSF}$ and $1 \mu \mathrm{g} / \mathrm{mL} \mathrm{PGE}{ }_{1}$ were added to the culture. ${ }^{20}$ Incubations were performed in analogy to Kit-D.

\section{MLC of T-Cell-Enriched Immune Reactive Cells With "Cocktails" Pretreated or Not Pretreated Stimulator Cell Suspensions From MNC or WB}

Immune reactive cells were enriched with $1 \times 10^{6}$ positively selected $\mathrm{CD}^{+} \mathrm{T}$ cells (effector cells) from AML patients or healthy controls and cocultured in 24-multiwell tissue culture plates (ThermoFisher Scientific) with a stimulator cell suspension containing $2.5 \times 10^{5} \quad \mathrm{DC} / \mathrm{DC}_{\text {leu }}$ (MLC*"MNC-DC" or MLC*"WB-DC" which were generated with different "cocktails." The same setting, but with a stimulatorcell suspension without pretreatment with "cocktails" (MLC*"MNC" or MLC*"WB") severed as a control. In 1 parallel tested case the stimulator cell suspensions were irradiated with $33 \mathrm{~Gy}$ to inactivate residual immune reactive cells (eg, iNKT/NK and CIK cells). The total volume of the cell culture was adjusted to $1 \mathrm{~mL}$ with RPMI-1640 medium (Biochrom) containing 1\% Penicillin (Biochrom) and $50 \mathrm{U} / \mathrm{mL}$ IL-2 (PeproTech). The MLC*"MNC" or MLC*"MNC-DC" further contained 15\% human serum (Healthcare Europe $\mathrm{GmbH}$, Vienna, Austria). After 2-3 days $50 \mathrm{U} / \mathrm{mL}$ IL-2 were added to the WB and MNC cultures. Half medium exchange for MNC cultures was carried out every 2-3 days. Cells were harvested after 6-9 days and were used for the cytotoxicity-fluorolysis assay as described below.

Before and after culture different cell subsets in the MNC-fraction and WB-fraction were quantified by flow cytometry (Table 1).

\section{Enzyme-linked Immunosorbent Assay (ELISA)}

Cell culture supernatants after AML-WB-DC culture stimulated with different "cocktails" ("Pici1," "Pici2," Kit-D, Kit-I, Kit-K, and Kit-M) and after MLC*"wB-DC" $(\mathrm{n}=4)$ were analyzed for IL-10, IL-17, Monocyte Chemoattractant Protein-1 (MCP-1) and interferon gamma (IFN- $\gamma$ ) secretion using the human IL-10, IL-17A, MCP-1, and IFN- $\gamma$ immunoassay kits (DRG Instruments $\mathrm{GmbH}$, Marburg, Germany). Moreover, WB-DC cultures without added response modifiers and MLC*"WB" severed as a control. The samples were evaluated with a Tristar LB941 ELISA reader (Berthold company, Bad Wildbach, Germany) and the concentration of the 4 different cytokines evaluated using the corresponding standard curve.

\section{Cell Characterization by Flow Cytometry}

Flow cytometric analyses were carried out to evaluate and quantify amounts, subsets and phenotypes of leukemic cells, B, T, iNKT, NK, and CIK cells, monocytes and DC in the MNC and WB fractions before and after different cultures. Panels with several moAbs labeled with fluorescein isothiocyanat (FITC), phycoerythrin (PE), tandem Cy7-PE conjugation (Cy7-PE), or allophycocyanin (APC) were used. Antibodies were provided by Beckman Coulter, Krefeld, Germany $\left({ }^{a}\right)$; Becton Dickinson, Heidelberg, Germany ( $\left.{ }^{b}\right)$; Biozol, Eching, Germany ( $\left.{ }^{\mathrm{c}}\right)$; Caltag, Darmstadt, Germany ( ${ }^{\mathrm{d}}$ ); Bioscience, Heidelberg, Germany ( ${ }^{\mathrm{e}}$ ); Miltenyi Biotech, Bergisch Gladbach, Germany $\left({ }^{\mathrm{f}}\right)$; and ThermoFisher Scientific ( $\left.{ }^{\mathrm{g}}\right)$. FITC-conjugated moAbs against $\mathrm{CD}^{\mathrm{a}}, \mathrm{CD}^{\mathrm{b}}, \mathrm{CD}^{\mathrm{a}}{ }^{\mathrm{a}}, \mathrm{CD} 34^{\mathrm{a}}, \mathrm{CD} 45 \mathrm{RO}^{\mathrm{a}}, \mathrm{CD}^{\mathrm{a}}{ }^{\mathrm{a}}$, $\mathrm{CD} 161^{\mathrm{b}}, 6 \mathrm{~B} 11^{\mathrm{c}}$, and $\mathrm{V} \alpha 24^{\mathrm{a}}$ were used. We used PEconjugated moAbs for $\mathrm{CD}_{1} \mathrm{~d}^{\mathrm{e}}, \mathrm{CD}^{\mathrm{a}}, \mathrm{CD}^{\mathrm{b}}, \mathrm{CD} 34^{\mathrm{a}}$, $\mathrm{CD} 80^{\mathrm{a}}, \mathrm{CD}^{2} 3^{\mathrm{a}}, \mathrm{CD} 117^{\mathrm{a}}, \mathrm{CD} 206^{\mathrm{a}}$, and $6 \mathrm{~B} 11^{\mathrm{b}}$. MoAbs against $\mathrm{CD}^{\mathrm{a}}, \mathrm{CD}^{\mathrm{a}}, \mathrm{CD}^{\mathrm{a}}, \mathrm{CD} 14^{\mathrm{b}}, \mathrm{CD} 15^{\mathrm{b}}, \mathrm{CD} 19^{\mathrm{a}}$, $\mathrm{CD} 34^{\mathrm{a}}, \mathrm{CD} 80^{\mathrm{b}}, \mathrm{CD} 117^{\mathrm{a}}$, and $\mathrm{CD} 197^{\mathrm{b}}$ were labeled with Cy7-PE. As APC-labeled moAbs we used CD1a ${ }^{\mathrm{a}}, \mathrm{CD}^{\mathrm{a}}$, $\mathrm{CD} 4^{\mathrm{a}, \mathrm{b}}, \mathrm{CD}^{\mathrm{a}}, \mathrm{CD}^{\mathrm{e}}, \mathrm{CD}^{\mathrm{b}}, \mathrm{CD} 10^{\mathrm{a}}, \mathrm{CD} 14^{\mathrm{a}}, \mathrm{CD} 15^{\mathrm{b}}$, $\mathrm{CD} 19^{\mathrm{a}}, \mathrm{CD}_{20}^{\mathrm{a}}, \mathrm{CD}_{3}{ }^{\mathrm{a}}, \mathrm{CD} 34^{\mathrm{a}, \mathrm{d}}, \mathrm{CD} 4 \mathrm{RO}^{\mathrm{d}}, \mathrm{CD}^{\mathrm{a}}{ }^{\mathrm{a}}$, $\mathrm{CD}^{\mathrm{b}}{ }^{\mathrm{b}}, \mathrm{CD}^{\circ} 6^{\mathrm{g}}, \mathrm{CD} 117^{\mathrm{a}}, \mathrm{CD} 133^{\mathrm{f}}, \mathrm{CD} 206^{\mathrm{b}}$, and CD209 ${ }^{\mathrm{b}}$. To detect dead cells $7 \mathrm{AAD}^{\mathrm{b}}$ was used.

Erythrocytes in WB samples were lysed using LysingBuffer (BD, Heidelberg, Germany) according to the manufacturer's instructions. To stain cells (MNC or WB) with moAbs they were resuspended in PBS (Biochrom), containing $5 \%-10 \%$ fetal calf-serum (Biochrome) to avoid unspecific bindings and were incubated for 15 minutes in the dark at room temperature. Afterwards cells were washed, centrifuged, and resuspended in 100-200 $\mu \mathrm{L}$ PBS. At least 5000 events were evaluated with a fluorescenceactivated cell-sorting Flow Cytometer (FACSCalibur) and 
Cell-Quest data acquisition and analysis software (Becton Dickson, Heidelberg, Germany). Isotype controls were conducted according to the manufacturer's instructions.

For the analysis and quantification of T, iNKT, NK, and CIK cells/subtypes were quantified in the total cellfraction (eg, $\mathrm{CD} 3{ }^{+}$cells) or in the subpopulations (eg, $\left.6 \mathrm{~B} 11^{+} \mathrm{CD}^{+}\right)$. According to their expression profile we quantified proportions of immune reactive cells as given in Table 1: $\mathrm{T}$ cells: $\mathrm{CD} 3^{+}, \mathrm{CD} 8^{+}, \mathrm{CD} 4^{+}, \mathrm{V} \alpha 24^{+}$, CD1d ${ }^{+} \mathrm{T}$-cells, $\mathrm{T}_{\text {naive }}, \mathrm{T}_{\text {non-naive, }} \mathrm{T}_{\mathrm{cm}}$ or $\mathrm{T}_{\mathrm{eff}-\mathrm{em}} \cdot{ }^{9}, 10,13 \mathrm{CIK}$ cells: $\mathrm{CD} 3{ }^{+} \mathrm{CD} 56^{+}$or $\mathrm{CD} 3{ }^{+} \mathrm{CD} 161^{+}$cells. $\mathrm{NK}$ cells: $\mathrm{CD}^{-}{ }^{-} \mathrm{CD} 56^{+}$or $\mathrm{CD} 3-\mathrm{CD} 161^{+}$cells. $^{5,13}\left(6 \mathrm{~B} 11^{+}\right) \mathrm{iNKT}$ cells: $6 \mathrm{~B} 11^{+} \mathrm{CD}^{+}, 6 \mathrm{~B} 11^{+} \mathrm{CD} 161^{+}, 6 \mathrm{~B} 11^{+} \mathrm{V} \alpha 24^{+}$, $6 \mathrm{~B} 11^{+} \mathrm{CD} 4{ }^{+}, 6 \mathrm{~B} 11^{+} \mathrm{CD} 8{ }^{+}, 6 \mathrm{~B} 11^{+} \mathrm{CD} 1 \mathrm{~d}^{+}, 6 \mathrm{~B} 11^{+}$ $\mathrm{CD} 45 \mathrm{RO}^{+}$or $6 \mathrm{~B} 11^{+} \mathrm{CD}^{+} 5 \mathrm{RO}^{-}{ }^{-} \mathrm{iNKT}^{-}$cells. Exemplarily, dot plots iNKT, NK, and CIK cells and the gating strategy of iNKT cells/subsets are given in Figure 1. Moreover, aberrant expressions of CD161 and $6 \mathrm{~B} 11$ on blasts were studied (Table 1). ${ }^{13}$

For the analysis and quantification of $\mathrm{DC} / \mathrm{DC}_{\text {leu }}$ subtypes in the total cell fraction or in subtype cell fraction after DC culture in the MNC or WB fraction $\left(\mathrm{DC}_{\text {leu }} /\right.$ cells) we used a refined gating strategy ${ }^{6,8}$ : subgroup analyses were conducted only in cases with $\geq 10 \%$ DC. $\mathrm{DC}_{\text {leu }}$ were quantified in the total fraction $\left(\mathrm{DC}_{\text {leu}} /\right.$ cells $)$ in the $\mathrm{DC}$ fraction $\left(\mathrm{DC}_{\text {leu }} / \mathrm{DC}\right)$ or in the blast fraction, to quantify the amount of blasts converted to $\mathrm{DC}_{\mathrm{leu}}\left(\mathrm{DC}_{\mathrm{leu}} / \mathrm{bla}\right)$, mature DC (coexpressing the migration marker CCR7) and viable DC (negative for 7AAD) were quantified in the DC fraction after culture $\left(\mathrm{DC}_{\mathrm{mig}} / \mathrm{DC} ; \mathrm{DC}_{\mathrm{via}} / \mathrm{DC}\right.$, Table 1 ,

1.1. Dot plots of NK-, CIK-, iNKT-cells in healthy or AML-MNC

A NK-and CIK-cells in healthy-(left side) or AML-MNC (right side)
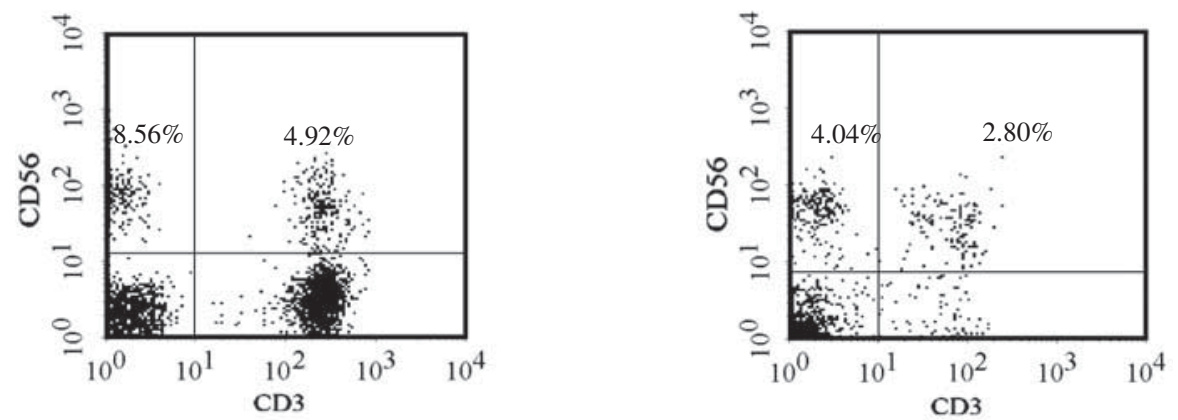

$\mathrm{B}$ iNKT-cells in healthy-(left side) or AML-MNC (right side)
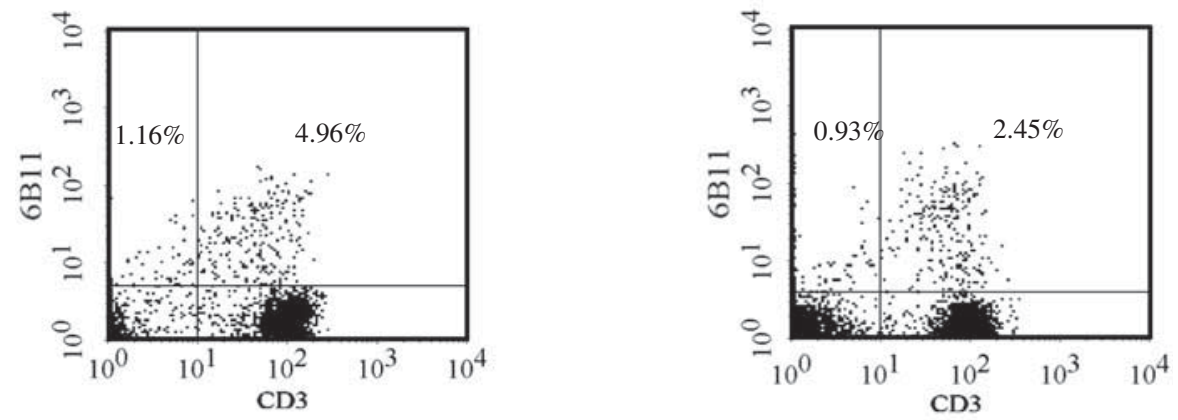

1.2. Gating of iNKT-subsets in AML-MNC
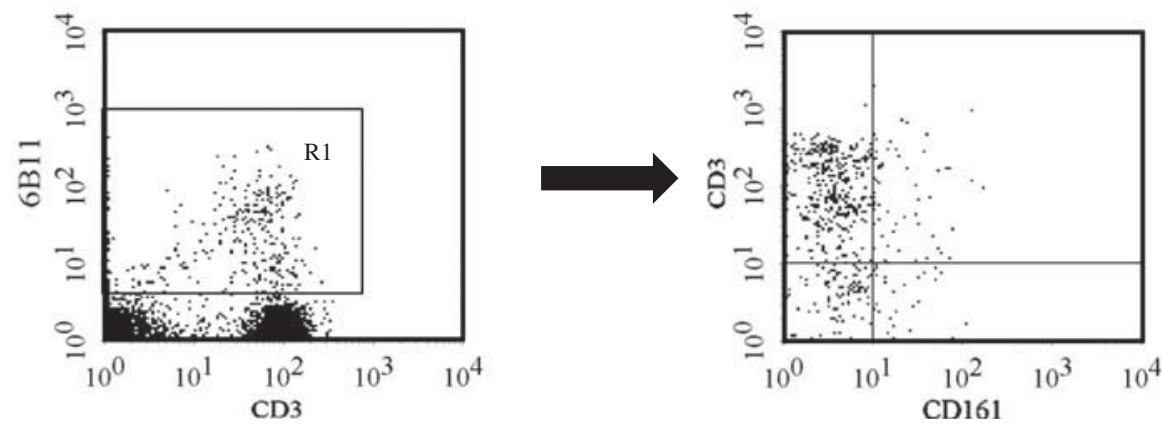

FIGURE 1. Gating strategy and corresponding dot plots of CIK, NK and iNKT cells in healthy or AML MNC are given. 1.1. Various frequencies of NK $\left(\mathrm{CD} 3^{-} \mathrm{CD}^{+} 6^{+}\right)$and $\mathrm{CIK}$ cells $\left(\mathrm{CD} 3^{+} \mathrm{CD} 56^{+}\right)$in healthy or AML MNC are given (A). Various frequencies of iNKT cells $\left(6 \mathrm{~B} 11^{+} \mathrm{CD} 3^{+}\right.$and $\left.6 \mathrm{~B} 11^{+} \mathrm{CD} 3^{-}\right)$in healthy or $\mathrm{AML}$ MNC are given (B). 1.2. Gating of $6 \mathrm{~B} 11^{+}$cells and characterization of corresponding subsets $\left(6 \mathrm{~B} 11^{+} \mathrm{CD} 3^{+} \mathrm{CD} 161^{+}, 6 \mathrm{~B} 11^{+} \mathrm{CD} 3^{-} \mathrm{CD} 161^{+}\right)$are given. $\mathrm{ALL}$ indicates acute lymphoid leukemia; $\mathrm{AML}$, acute myeloid leukemia; CIK, cytokine-induced killer; MNC, mononuclear cells; NK, natural killer; iNKT, invariant natural killer T. R1 = gate surrounding all $6 \mathrm{~B} 11+$ cells in the AML-MNC fraction. 
lower part). For this purpose, cells were stained with patient-specific "blast"-staining antibodies (eg, CD15, CD34, CD65, and CD117) according to diagnostic reports before culture in combination with "DC"-staining antibodies (eg, CD80, CD83, CD86, CD206, and CD209), which were not expressed before culture.

\section{Cytotoxicity (Fluorolysis) Assay}

To analyze the blast lytic activity of T-cell-enriched immune reactive cells after MLC with "cocktails"-pretreated or not pretreated stimulator cell suspensions from MNC or WB a fluorolysis assay was performed. ${ }^{19}$ Therefore, effector cells (E) were cocultured 1:1 with thawed blast-containing target cells (T) for 3 and 24 hours at $37^{\circ} \mathrm{C}$, with $21 \% \mathrm{O}_{2}$ and $5 \% \mathrm{CO}_{2}$. As a control effector cells and target cells were cultured for the same time separately and mingled on ice shortly before the flow cytometric analyses were carried out. Before culture, target cells were stained for 15 minutes with FITC, PE or APC-conjugated blast, monocyte or T cell-specific target cell antibodies. To evaluate viable cells and the lytic activity of effector cells, the cultures were harvested after 3 and 24 hours and resuspended in PBS containing 7AAD (Becton Dickson) and a defined number of Fluorospheres beads (Beckman Coulter). For analyses, a refined gating was used. ${ }^{8}$ Therefore, viable target cells were gated in a FSC/7AAD ${ }^{-}$ gate. With a FACS Calibur Flow Cytometer and a Cell-Quest software (Becton Dickson) cells were analyzed. The lytic activity was calculated and defined as the difference in the percentage of viable target blasts before and after the effector cell contact.

\section{Statistical Methods}

Data were presented as mean $\pm \mathrm{SD}$. Statistic comparisons for 2 groups were performed using the $t$ test and MannWhitney-Wilcoxon test. The statistical analysis was done with Microsoft Excel 2010 or 2013 (Microsoft, Redmond, WA) and JMP10.0 statistical software (SAS Institute, Cary, NY). Differences were considered as "not significant" (ns) with $P$-values $>0.1$, as "borderline significant" (significant*) with $P$-values between 0.1 and 0.05 , as "significant" (significant**) with $P$-values between 0.05 and 0.005 and as "highly significant" (significant***) with $P$-values $<0.005$.

\section{RESULTS}

\section{Prolog}

During the development of acute and chronic leukemia B, T lymphocytes and monocytes are displaced by increasing blast cell-populations. In our samples between $8 \%$ and $99 \%$ of blast cells and varying proportions of the remaining hematopoietic cells were detectable. Details of the cellular composition of AML/ALL/CLL samples are shown in Table 4. Samples with blasts, that aberrantly expressed CD3, CD4, CD8, CD14 or CD19, were excluded from quantification analyses for the respective lineage markers.

In our first approach, we compared frequencies and compositions of iNKT, NK, CIK cells as well as T cell subtypes in (unstimulated) MNC from healthy donors with AML, ALL and CLL patients and correlated findings with prognosis of these patients. Moreover, we studied potential (aberrant) coexpressions of iNKT markers on leukemic cell lines. In our second approach we analyzed proportions of AML blasts and immune reactive cells (with a special focus on iNKT, NK, and CIK cells) and their expression profiles after MLC.
TABLE 4. Cellular Composition of AML/ALL/CLL and Healthy Samples

\begin{tabular}{ccc} 
& $\varnothing(\mathrm{MNC})$ & Range (MNC) \\
Cell Type & $(\%)$ & $(\%)$ \\
\hline
\end{tabular}

4.1. AML/ALL/CLL and healthy samples used for surface marker expression analyses

\begin{tabular}{|c|c|c|c|}
\hline & $\begin{array}{l}\text { Blasts (myeloid } \\
\text { blasts) }\end{array}$ & 69 & $18-99$ \\
\hline \multirow[t]{4}{*}{ AML } & $\mathrm{T}$ cells $\left(\mathrm{CD} 3^{+}\right)$ & 6 & $1-33$ \\
\hline & $\mathrm{B}$ cells $\left(\mathrm{CD} 19^{+}\right)$ & 6 & $1-33$ \\
\hline & $\begin{array}{c}\text { Monocytes } \\
\left(\mathrm{CD} 14^{+}\right)\end{array}$ & 8 & $2-18$ \\
\hline & $\begin{array}{l}\text { Blasts ( } \mathrm{B} \text { or } \mathrm{T} \\
\text { lineage blasts) }\end{array}$ & 71 & $17-99$ \\
\hline \multirow{4}{*}{ ALL } & $\mathrm{T}$ cells $\left(\mathrm{CD} 3^{+}\right)^{*}$ & 14 & $5-33$ \\
\hline & $\mathrm{B}$ cells $\left(\mathrm{CD} 19^{+}\right) \dagger$ & 8 & $3-11$ \\
\hline & $\begin{array}{l}\text { Monocytes } \\
\left(\mathrm{CD} 14^{+}\right)\end{array}$ & 5 & $1-29$ \\
\hline & $\begin{array}{c}\text { Blasts (B lineage } \\
\text { blasts) }\end{array}$ & 85 & $32-98$ \\
\hline \multirow[t]{3}{*}{ CLL } & $\mathrm{T}$ cells $\left(\mathrm{CD} 3^{+}\right)$ & 11 & $1-60$ \\
\hline & $\begin{array}{l}\text { Monocytes } \\
\left(\mathrm{CD} 14^{+}\right)\end{array}$ & 4 & $1-25$ \\
\hline & $\mathrm{T}$ cells $\left(\mathrm{CD}^{+}\right)$ & 41 & $24-64$ \\
\hline \multirow[t]{3}{*}{ Healthy } & $\mathrm{B}$ cells $\left(\mathrm{CD} 19^{+}\right)$ & 24 & $14-32$ \\
\hline & $\begin{array}{l}\text { Monocytes } \\
\left(\mathrm{CD} 14^{+}\right)\end{array}$ & 3 & $1-6$ \\
\hline & Cell type & $\begin{array}{c}\varnothing(\mathrm{WB} / \\
\mathrm{MNC})(\%)\end{array}$ & $\begin{array}{l}\text { Range (WB/ } \\
\text { MNC) }(\%)\end{array}$ \\
\hline \multicolumn{4}{|c|}{ 4.2. AML and healthy samples used for culture experiments } \\
\hline \multirow{5}{*}{$\mathrm{AML}$} & Blasts & $28 / 17$ & $8-60 / 15-18$ \\
\hline & $\mathrm{T}$ cells $\left(\mathrm{CD} 3^{+}\right)$ & $21 / 11$ & $2-54 / 5-17$ \\
\hline & $\mathrm{B}$ cells $\left(\mathrm{CD}^{+} 9^{+}\right)$ & $1 / 5$ & $0-2 / 2-8$ \\
\hline & $\begin{array}{l}\text { Monocytes } \\
\left(\mathrm{CD} 14^{+}\right)\end{array}$ & $11 / 7$ & $0-32 / 3-13$ \\
\hline & $\mathrm{T}$ cells $\left(\mathrm{CD}^{+}{ }^{+}\right)$ & $18 / 35$ & $14-21 / 9-48$ \\
\hline \multirow[t]{2}{*}{ Healthy } & $\mathrm{B}$ cells $\left(\mathrm{CD} 19^{+}\right)$ & $3 / 7$ & $1-4 / 3-12$ \\
\hline & $\begin{array}{l}\text { Monocytes } \\
\left(\mathrm{CD} 14^{+}\right)\end{array}$ & $6 / 7$ & $5-8 / 3-12$ \\
\hline
\end{tabular}

*Only quantified in B lineage ALL.

†Only quantified in T lineage ALL.

ALL indicates acute lymphoid leukemia; AML, acute myeloid leukemia; CLL, chronic lymphoid leukemia; MNC, mononuclear cells; WB, whole blood; Ø, mean.

The 6B11-antibody, targeting the invariant CDR3 loop of the $\mathrm{V} \alpha 24 \mathrm{~J} \alpha 18 \mathrm{TCR}$, is regarded as a specific antibody to detect iNKT cells. In our experiments, we used 2 different antibodies: 6B11 (clone 6B11) labeled with PE (6B11-PE, delivered by BD) and 6B11 (clone 6B11) labeled with FITC (6B11-FITC, delivered by Biozol). First comparative analyses with these markers in MNC from AML, ALL, CLL patients revealed significantly* higher proportions of iNKT cells detected with the 6B11FITC compared with 6B11-PE (AML: $1.52 \% \pm 1.74 \%$ vs. $0.75 \% \pm 1.10 \%, P<0.0652$; ALL: $1.24 \% \pm 1.52 \%$ vs. $0.74 \% \pm 0.64 \%, \quad P<0.103$; CLL: $0.92 \% \pm 0.87 \%$ vs. $0.78 \% \pm 0.47 \%, \quad P<0.299)$. However, proportions of iNKT cells detected with 6B11-FITC were significantly** lower in healthy samples compared with leukemic samples (AML: $0.40 \% \pm 0.26 \%$ vs. $1.52 \% \pm 1.74 \%, P<0.01073$; ALL: $0.40 \% \pm 0.26 \%$ vs. $1.24 \% \pm 1.52 \%, P<0.01622$ CLL: $0.40 \% \pm 0.26 \%$ vs. $0.92 \% \pm 0.87 \%, P<0.02267$ ), 
while iNKT cells detected with 6B11-PE were significantly* higher in healthy samples compared with leukemic samples (AML: $2.47 \% \pm 3.12 \%$ vs. $0.75 \% \% \pm 1.10 \%, P<0.081$; ALL: $2.47 \% \pm 3.12 \%$ vs. $0.74 \% \pm 0.65 \%, \quad P<0.083$; CLL: $2.47 \% \pm 3.12 \%$ vs. $0.78 \% \pm 0.47 \%, P<0.0827)$. We decided for better comparibility to present only data obtained with 6B11-PE.

We evaluated 8 different leukemic cell lines (HL-60, OCI-AML2, THP-1, Mono-Mac-6, MOLM-13, RAMOS, RAJI, JURKAT) to analyze if $6 \mathrm{~B} 11$ or CD161 is aberrantly expressed on blasts. We could demonstrate that neither CD161 nor 6B11 were (aberrantly) expressed on blasts of leukemic myeloid and B lineage cell lines with a mean coexpression on blasts of $2.59 \% \pm 0.02 \%$ or $2.67 \% \pm 0.03 \%$. However, $8.38 \% 6 \mathrm{~B} 11^{+} \mathrm{bla}^{+}$and $10.03 \% \mathrm{CD} 61{ }^{+} \mathrm{bla}^{+}$ cells were found in the T-linear Jurkat cell line. Moreover, we could demonstrate that neither CD161 nor 6B11 were aberrantly expressed on leukemic blasts obtained from patients with AML, ALL or CLL. On average, coexpression of CD161 and 6B11 on blasts was: AML: $0.23 \% \pm 0.01 \%$ or $0.35 \% \pm 0.01 \%$; ALL: $0.55 \% \pm 0.01 \%$ or $0.66 \% \pm 0.01 \%$; CLL: $0.17 \% \pm 0.00 \%$ or $1.60 \% \pm 0.01 \%$.

Therefore, analyzing iNKT cells with 6B11-PE and $\mathrm{NK} / \mathrm{CIK}$ cells with CD161 represent specific results as 6B11 and CD161 antibodies do not show unspecific bindings on blasts, although combinations of (fluorochrome)-labeled antibodies have to be tested thoroughly.

\section{moAbs and their Combinations for iNKT, NK, and CIK Cell/Subtype Analyses}

For iNKT cell detection in healthy and AML, ALL, and CLL samples, we used moAb 6B11 alone or in combination with CD3, CD161, V 224 , CD1d, CD45RO, CD4, and CD8. We defined iNKT cells detected with 6B11 in combination with T cell markers (CD3, V 224, CD1d, CD45RO, CD4, and CD8) as "T cell-like" iNKT cells and iNKT cells detected with 6B11 in combination with NK cell markers (CD161) as "NK celllike" iNKT cells. The frequencies of iNKT cells detected with 6B11 alone were similar in AML, ALL, and CLL patients $(0.75 \% \pm 1.10 \%$ vs. $0.74 \% \pm 0.65 \%$ vs. $0.78 \% \pm 0.47 \%)$. Frequencies of iNKT cells detected with $6 \mathrm{~B} 11$ in combination with $\mathrm{CD} 3\left(6 \mathrm{~B} 11^{+} \mathrm{CD} 3{ }^{+} / \mathrm{MNC}\right)$ were slightly lower in AML, ALL, and CLL patients $(0.58 \% \pm 1.15 \%$ vs. $0.61 \% \pm 0.42 \%$ vs. $0.46 \% \pm 0.47 \%$ ), but the percentages were comparable to results with $6 \mathrm{~B} 11$ in combination with CD1d $\left(6 \mathrm{~B} 11+{ }^{+} \mathrm{CD}_{1 \mathrm{~d}}+\mathrm{MNC}, 0.66 \% \pm 1.16 \%\right.$ vs. $0.66 \% \pm 0.96 \%$ vs. $0.48 \% \pm 0.64 \%$ ). Proportions of $6 \mathrm{~B} 11^{+} \mathrm{CD} 161^{+} / \mathrm{MNC}$ iNKT cells were even smaller in AML, ALL, and CLL patients $(0.14 \% \pm 0.25 \%$ vs. $0.18 \% \pm 0.16 \%$ vs. $0.22 \% \pm 0.26 \%)$, while $6 \mathrm{~B} 11+\mathrm{V} \alpha 24+/ \mathrm{MNC}$ could only detect very few frequencies of iNKT cells $(0.09 \% \pm 0.10 \%$ vs. $0.08 \% \pm 0.18 \%$ vs. $0.03 \% \pm 0.03 \%$ ). We could show higher frequencies of $6 \mathrm{~B} 11+\mathrm{CD} 4+/ \mathrm{MNC}$ versus $6 \mathrm{~B} 11^{+} \mathrm{CD} 8{ }^{+} / \mathrm{MNC}$ iNKT cells detected in AML, ALL, and CLL patients (CD4 ${ }^{+}$iNKT cells: $0.18 \% \pm 0.20 \%$ vs. $0.32 \% \pm 0.33 \%$ vs. $0.25 \% \pm 0.12 \%$; CD8 ${ }^{+}$iNKT cells: $0.03 \% \pm 0.04 \%$ vs. $0.07 \% \pm 0.09 \%$ vs. $0.06 \% \pm 0.05 \%$ ). Moreover, we could show that the majority of $6 \mathrm{~B} 11^{+}$iNKT cells express CD45RO in AML, ALL, and CLL patients $(88.58 \% \pm 14,43 \%$ vs. $79.75 \% \pm 30.00 \%$ vs. $64.58 \% \pm 29.53 \%$ ).

In conclusion, frequencies of iNKT cells and their subsets can be detected with 6B11 alone (PE-labeled clone preferred) or in combination with CD3, CD161, CD1d or V 224. The combination of $6 \mathrm{~B} 11$ with CD4, CD8, and CD45RO can be used for further subset-analyses of iNKT cells.

\section{Frequencies and Compositions of iNKT, NK, and CIK Cells From AML Patients Compared With Healthy Controls and their Correlation With Prognosis}

AML Patients Show Significantly Lower Proportions of iNKT, NK, and CIK Cells in MNC Compared With Healthy MNC

We found significantly*** lower frequencies of $\mathrm{CD}^{+}$ $\mathrm{CD}^{+} 6^{+} \mathrm{CIK}$ cells in MNC of AML patients compared with healthy MNC $(0.46 \% \pm 0.62 \%$ vs. $2.74 \% \pm 1.64 \%, P<0.0021)$ and significantly*** lower percentages of $\mathrm{CD}^{+} \mathrm{CD} 161^{+}$ CIK cells $(0.30 \% \pm 0.40 \%$ vs. $3.25 \% \pm 1.02 \%, P<0.000152$, Fig. 2A). In addition, we could show significantly*** lower proportions of $\mathrm{CD}^{-} \mathrm{CD}^{-} 6^{+} \mathrm{NK}$ cells $(1.68 \% \pm 1.97 \%$ vs. $9.33 \% \pm 4.06 \%, P<0.00064)$ and significantly** lower proportions of $\mathrm{CD}^{-}{ }^{-} \mathrm{CD} 161^{+} \mathrm{NK}$ cells in MNC of AML patients compared with healthy $\mathrm{MNC}(1.01 \% \pm 1.26 \%$ vs. $2.44 \% \pm 1.20 \%, P<0.0142$, Fig. 2B). We could demonstrate significantly* lower percentages of $6 \mathrm{~B} 11^{+}$iNKT cells $(0.75 \% \pm 1.10 \%$ vs. $2.47 \% \pm 3.12 \%, P<0.081)$ and (ns) lower proportions of $6 \mathrm{~B} 11^{+} \mathrm{CD} 3{ }^{+}$and $6 \mathrm{~B} 11^{+} \mathrm{CD} 161^{+} \mathrm{iNKT}$ cells in $\mathrm{MNC}$ of $\mathrm{AML}$ patients compared with healthy $\mathrm{MNC}$ (Fig. 2C). Moreover, $6 \mathrm{~B} 11^{+} \mathrm{CD} 8{ }^{+}$and $6 \mathrm{~B} 11^{+} \mathrm{V} \alpha 24^{+}$iNKT cells were found in lower proportions in $\mathrm{MNC}$ from $\mathrm{AML}$ patients versus healthy MNC [data not shown (dns)].

In summary frequencies of $6 \mathrm{~B} 11^{+} / 6 \mathrm{~B} 11^{+} \mathrm{CD} 3^{+} /$ $6 \mathrm{~B} 11^{+} \mathrm{CD}_{161}{ }^{+} / 6 \mathrm{~B} 11^{+} \mathrm{CD} 8{ }^{+} / 6 \mathrm{~B} 11^{+} \mathrm{V} \alpha 24^{+} \mathrm{iNKT} \mathrm{CD} 3^{-}$ $\mathrm{CD}_{6}{ }^{+} / \mathrm{CD}^{-}{ }^{-} \mathrm{CD} 161^{+} \mathrm{NK}$, and $\mathrm{CD}^{+}{ }^{+} \mathrm{CD} 56^{+} / \mathrm{CD} 3{ }^{+}$ $\mathrm{CD} 161^{+} \mathrm{CIK}$ cells/subsets were (significantly) lower in MNC from AML patients than in healthy MNC.

\section{(Significantly) Higher Proportions of T and NK Cells Express 6B11 in AML Patients Compared With Healthy Controls}

We found significantly*** increased proportions of $\mathrm{CD} 3^{+}$ T cells expressing 6B11 in AML patients compared with healthy controls $(14.03 \% \pm 14.66 \%$ vs. $2.69 \% \pm 2.17 \%, P<0.00111$, Fig. 2D). Moreover, we found significantly** higher frequencies of CD4 ${ }^{+}(8.36 \% \pm 15.22 \%$ vs. $0.31 \% \pm 0.38 \%, P<0.0123)$ and $\mathrm{CD} 161^{+}$cells expressing $6 \mathrm{~B} 11(17.19 \% \pm 15.36 \%$ vs. $4.62 \% \pm 5.97 \%, \quad P<0.0152$, Fig. 2D) and significantly* increased frequencies of $\mathrm{CD} 8{ }^{+}$cells expressing $6 \mathrm{~B} 11$ in $\mathrm{MNC}$ of AML patients versus healthy controls $(1.89 \% \pm 3.55 \%$ vs. $0.59 \% \pm 1.12 \%, P<0.0723)$. We did not find significant differences of $\mathrm{CD}^{+}{ }^{+} \mathrm{CD} 161^{+} \mathrm{CIK}$ cells in the $\mathrm{CD} 3^{+} \mathrm{T}$ cell fraction of AML patients compared with $\mathrm{CD} 3{ }^{+} \mathrm{CD} 161{ }^{+} \mathrm{CIK}$ cells in the healthy $\mathrm{T}$ cell fraction (dns).

In summary a shift to higher proportions of $\left(\mathrm{CD} 3^{+} /\right.$ $\left.\mathrm{CD} 4{ }^{+} / \mathrm{CD}^{+}{ }^{+}\right) \mathrm{T}$ cells and $\left(\mathrm{CD} 161^{+}\right) \mathrm{NK}$ cells coexpressing $6 \mathrm{~B} 11$ was found in AML patients compared with healthy samples. No differences of $\mathrm{CD} 3{ }^{+} \mathrm{CD} 161^{+} \mathrm{CIK}$ cells in the $\mathrm{CD}^{+}{ }^{+} \mathrm{T}$-cell fraction were observed.

\section{AML Patients With Prognostically Favorable Subgroups are Characterized by Higher Proportions of iNKT, NK, and CIK Cells}

AML patients who achieved CR after induction chemotherapy were characterized by significantly** higher frequencies of $\mathrm{CD} 3{ }^{+} \mathrm{CD} 56^{+}$CIK cells in MNC-fractions than AML patients with no complete remission (NCR; $0.4 \% \pm 0.33 \%$ vs. $0.05 \% \pm 0.05 \%, P<0.0094$, Fig. $5.1 \mathrm{~A}$, left side), whereas proportions of NK or iNKT cells were not different in MNC fractions of patients who achieved versus not achieved a CR (dns). AML-patients with 
A CIK-cell-frequencies in $\mathrm{MNC}$

$\mathrm{CD3}^{+} \mathrm{CD56}^{+} / \mathrm{MNC}$

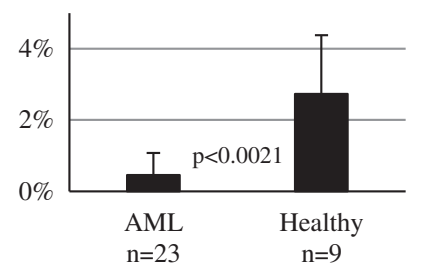

$B$ NK-cell-frequencies in MNC

$\mathrm{CD3}^{-\mathrm{CD56}^{+} / \mathrm{MNC}}$

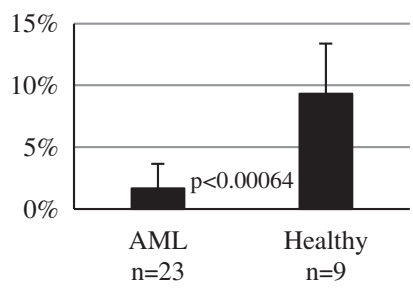

$\mathrm{CD3}^{+} \mathrm{CD} 161^{+} / \mathrm{MNC}$

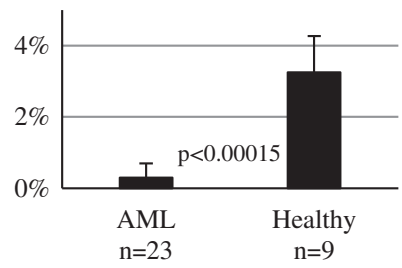

$n=23 \quad n=9$

CD3-CD161 $^{+} /{ }^{-M N C}$

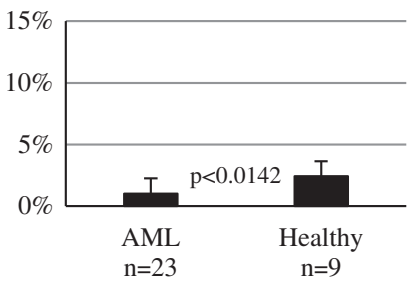

C iNKT-cell-frequencies in MNC

6B11 + MNC

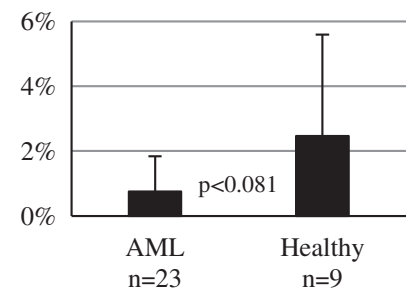

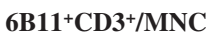

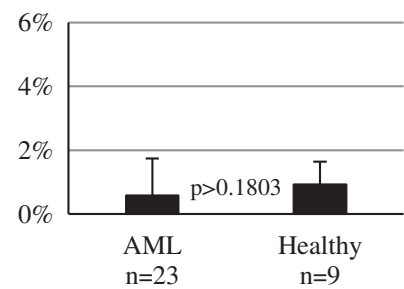

$6 \mathrm{~B} 11^{+}{ }^{\mathrm{CD} 161}+/ \mathrm{MNC}$

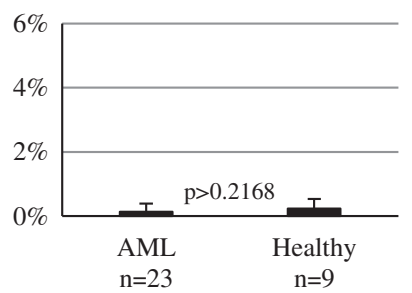

D iNKT-cell-subsets in T-/NK-cell-fraction

$\mathrm{6B}^{+}{ }^{+} \mathrm{CD3}^{+} / \mathrm{CD3}^{+}$

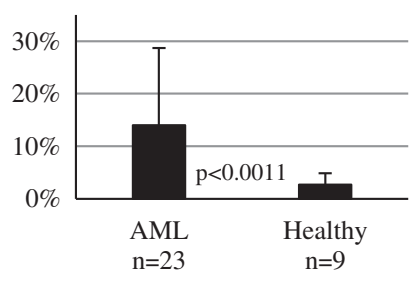

6B11 $^{+} \mathrm{CD} 161^{+} / \mathrm{CD} 161^{+}$

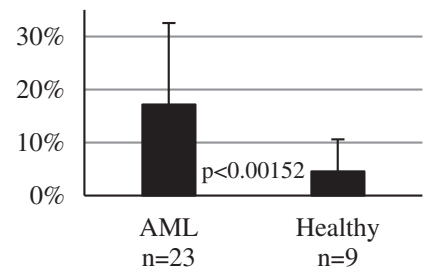

FIGURE 2. Frequencies of CIK, NK and iNKT cells and their subsets in healthy versus AML MNC are given. Percentages of CIK cells $\left(\mathrm{CD} 3{ }^{+} \mathrm{CD} 56^{+} / \mathrm{MNC}\right.$ and $\left.\mathrm{CD} 3{ }^{+} \mathrm{CD} 161^{+} / \mathrm{MNC}\right)(\mathrm{A})$, NK cells $\left(\mathrm{CD} 3^{-} \mathrm{CD} 56^{+} / \mathrm{MNC}\right.$ and $\left.\mathrm{CD} 3-\mathrm{CD} 161^{+} / \mathrm{MNC}\right)(\mathrm{B})$, iNKT cells in MNC $\left(6 \mathrm{~B} 11^{+}, 6 \mathrm{~B} 11^{+} \mathrm{CD} 3^{+} / \mathrm{MNC}, 6 \mathrm{~B} 11^{+} \mathrm{CD} 161^{+} / \mathrm{MNC}\right)(\mathrm{C})$, and iNKT cell subsets in the $\mathrm{T}$ cell fraction $\left(6 \mathrm{~B} 11^{+} \mathrm{CD}^{+} / \mathrm{CD}^{+}\right)$and in the NK cell fraction $\left(6 \mathrm{~B} 11^{+} \mathrm{CD} 161^{+} / \mathrm{CD} 161^{+}\right)(\mathrm{D})$ are given. $\mathrm{ALL}$ indicates acute lymphoid leukemia; $\mathrm{AML}$, acute myeloid leukemia; $\mathrm{CIK}$ cytokine-induced killer; MNC, mononuclear cells; NK, natural killer; iNKT, invariant natural killer T.

favorable versus adverse NCCN risk-score presented with (ns) higher values of $6 \mathrm{~B} 11^{+}-\mathrm{iNKT}$ cells in the MNCfraction $(0.64 \% \pm 0.11 \%$ vs. $0.56 \% \pm 0.09 \%$; Fig. 5.1A, middle row). Comparable results were found for $6 \mathrm{~B} 11^{+}$ $\mathrm{Va} 24^{+}$and $6 \mathrm{~B} 11^{+} \mathrm{CD} 161{ }^{+} \mathrm{iNKT}$ cell-proportions in the MNC-fraction of AML-patients with favorable versus adverse NCCN risk-score (dns).

AML-patients younger than 60 years presented with (ns) higher frequencies of $6 \mathrm{~B} 11{ }^{+}{ }^{i N K T}$ cells in the MNC-fraction compared with AML-patients older than 60 years $(0.89 \% \pm 1.35 \%$ vs. $0.53 \% \pm 0.40 \%$, Fig. $5.1 \mathrm{~A}$, right side $)$. Comparable results were found for $6 \mathrm{~B} 11^{+} \mathrm{CD}^{+}$and $6 \mathrm{~B} 11^{+} \mathrm{CD} 161{ }^{+} \mathrm{iNKT}$ cell proportions in the MNC-fraction of AML-patients younger than 60 years versus older than 60 years (dns). No differences were found for proportions of NK or CIK cells in the groups compared (dns).

AML-patients with primary versus secondary AML presented with (ns) higher frequencies of $6 \mathrm{~B} 11^{+}$and $6 \mathrm{~B} 11^{+}$ $\mathrm{CD}^{+}{ }^{+}$iNKT cells in the MNC-fraction $(0.78 \% \pm 1.21 \%$ vs. $0.62 \% \pm 0.46 \% ; \quad 0.66 \% \pm 1.29 \%$ vs. $0.32 \% \pm 0.23 \%)$. No differences were found for proportions of NK or CIK cells in the groups compared (dns).

AML-patients without extramedullary foci $(n=20)$ compared with those with extramedullary foci $(\mathrm{n}=3)$ presented with significantly*** increased proportions of $\mathrm{CD} 3{ }^{+} \mathrm{CD} 56{ }^{+} \mathrm{CIK}$ cells in the MNC-fraction $(0.53 \% \pm 0.63 \%$ vs. $0.00 \% \pm 0 \%$, 
$P<0.0023$; Fig. 5.1B left side). Moreover, the percentages of $\mathrm{CD}^{-} \mathrm{CD}^{-} 6^{+} \mathrm{NK}$ cells was significantly*** higher in cases without compared with patients with extramedullary foci $(1.97 \% \pm 0.21 \%$ vs. $0.08 \% \pm 0.04 \%, P<0.0017$, Fig. 5.1B, middle row) Furthermore we found (ns) higher frequencies of $6 \mathrm{~B} 11^{+}$iNKT cells in the MNC fraction of AML-patients without versus with extramedullary foci $(0.81 \% \pm 1.16 \%$ vs. $0.37 \% \pm 0.24 \%$; Fig. 5.1B right side). Comparable results were found for $6 \mathrm{~B} 11^{+} \mathrm{CD}^{+}$and $6 \mathrm{~B} 11^{+} \mathrm{CD} 161{ }^{+} \mathrm{iNKT}$ cellproportions in the MNC-fraction in the groups compared (dns).

AML-patients who stayed in stable CR versus no stable $\mathrm{CR}$ (NCR) showed (ns) higher frequencies of $\mathrm{CD} 3{ }^{+} \mathrm{CD} 161^{+}$ CIK cells and $\mathrm{CD}^{-}{ }^{-} \mathrm{CD} 161^{+} \mathrm{NK}$ cells in the MNC-fraction $(0.47 \% \pm 0.58 \%$ vs. $0.16 \% \pm 0.08 \% ; 1.21 \% \pm 1.73 \%$ vs. $0.90 \% \pm 072 \%$; Fig. $5.1 \mathrm{C}$ left side, middle row). Moreover, we found (ns) higher percentages of $6 \mathrm{~B} 11^{+} \mathrm{iNKT}$ cells in the MNC-fraction of AML-patients who stayed in stable CR versus NCR $(1.04 \% \pm 1.63 \%$ vs. $0.37 \% \pm 0.10 \%$; Fig. $5.1 \mathrm{C}$, right side). Comparable results were found for $6 \mathrm{~B} 11^{+} \mathrm{CD} 3{ }^{+}$ and $6 \mathrm{~B} 11^{+} \mathrm{CD} 161^{+}$iNKT cell proportions in the MNC fraction in the groups compared (dns).

In summary in AML-patients (significantly) higher proportions of $6 \mathrm{~B} 11^{+}$iNKT cells correlated with favorable NCCN risk-score, younger age, primary AML, no extramedullary foci and stable CR. Similar correlations were found for $6 \mathrm{~B} 11^{+} \mathrm{CD} 3{ }^{+} / 6 \mathrm{~B} 11^{+} \mathrm{CD} 161^{+}$and $6 \mathrm{~B} 11^{+}$ $\mathrm{V} \propto 24^{+}$iNKT-subsets. High frequencies of $\mathrm{CD} 3^{-\mathrm{CD} 56}$ $\mathrm{NK}$ cells and $\mathrm{CD} 3{ }^{+} \mathrm{CD} 56^{+}$CIK cells NK and CIK cells correlated significantly with no extramedullary foci. Moreover, higher proportions of CD3 ${ }^{-} \mathrm{CD} 161^{+}$NK cells and CD $3{ }^{+} \mathrm{CD} 161{ }^{+} \mathrm{CIK}$ cells correlated with stable CR in AML-patients and $\mathrm{CD} 3{ }^{+} \mathrm{CD} 56^{+} \mathrm{CIK}$ cells correlated with the achievement of $\mathrm{CR}$ after induction chemotherapy in AML-patients.

\section{Frequencies and Subtypes of iNKT, NK, and CIK Cells From ALL-Patients Compared With Healthy Controls and their Correlation With Prognosis}

ALL-Patients Show Significantly Lower Proportions of iNKT, NK, and CIK Cells in MNC Compared With Healthy MNC

We found significantly** lower frequencies of $\mathrm{CD} 3^{+}$ CD56 ${ }^{+}$CIK cells in MNC of ALL-patients compared with healthy MNC $(1.36 \% \pm 1.63 \%$ vs. $2.74 \% \pm 1.64 \%$, $P<0.0395)$ and significantly*** lower percentages of $\mathrm{CD} 3{ }^{+}$ CD $161{ }^{+}$CIK cells $(0.94 \% \pm 1.45 \%$ vs. $3.25 \% \pm 1.02 \%$, $P<0.00039$, Fig. 3A). Moreover, we found significantly*** lower proportions of $\mathrm{CD}^{-}{ }^{-} \mathrm{CD} 56^{+} \mathrm{NK}$ cells $(2.68 \% \pm 2.35 \%$ vs. $9.33 \% \pm 4.06 \%, P<0.00163)$ and significantly*** lower proportions of CD3 ${ }^{-} \mathrm{CD} 161{ }^{+} \mathrm{NK}$ cells in MNC of ALL-patients versus healthy $\mathrm{MNC}(0.52 \% \pm 0.92 \%$ vs. $2.44 \% \pm 1.20 \%$, $P<0.00344$, Fig. 3B). We could show significantly* lower frequencies of $6 \mathrm{~B} 11^{+} \mathrm{iNKT}$ cells in MNC of ALL-patients versus healthy $\mathrm{MNC}(0.74 \% \pm 0.65 \%$ vs. $2.47 \% \pm 3.12 \%$, $P<0.083$, Fig. 3C). Moreover, $6 \mathrm{~B} 11^{+} \mathrm{CD}^{+} / 6 \mathrm{~B} 11^{+} \mathrm{CD} 8{ }^{+} /$ $6 \mathrm{~B} 11^{+} \mathrm{CD} 161^{+}$and $6 \mathrm{~B} 11^{+} \mathrm{V} \alpha 24^{+}$iNKT cells were found in (ns) lower proportions in MNC from ALL-patients versus healthy MNC (dns).

In summary frequencies of $6 \mathrm{~B} 11^{+} / 6 \mathrm{~B} 11^{+} \mathrm{CD} 3+/$ $6 \mathrm{~B} 11^{+} \mathrm{CD} 161^{+} / 6 \mathrm{~B} 11^{+} \mathrm{CD} 8{ }^{+} / 6 \mathrm{~B} 11^{+} \mathrm{V} \alpha 24^{+}$iNKT, $\mathrm{CD}^{-}{ }^{-} \mathrm{CD} 56^{+} / \mathrm{CD} 3-\mathrm{CD} 161^{+} \mathrm{NK}$, and $\mathrm{CD}^{+}{ }^{+} \mathrm{CD} 56^{+} /$ $\mathrm{CD} 3{ }^{+} \mathrm{CD}_{161}{ }^{+} \mathrm{CIK}$ cells/subsets were (significantly) lower in ALL-MNC than in healthy MNC.
(Significantly) Higher Proportions of $T$ and NK Cells Express 6B11 in ALL-Patients Compared With Healthy Controls

We found significantly* lower percentages of $\mathrm{CD}^{+}$ $\mathrm{CD} 161^{+} \mathrm{CIK}$ cells in the $\mathrm{CD} 3^{+}$T-cell fraction of ALL-patients compared with $\mathrm{CD} 3{ }^{+} \mathrm{CD} 161{ }^{+} \mathrm{CIK}$ cells in the healthy $\mathrm{CD} 3{ }^{+}$ T-cell fraction $(5.25 \% \pm 7.17 \%$ vs. $8.92 \% \pm 2.82 \%, P<0.053)$, but significantly** higher proportions of $\mathrm{CD}^{+} \mathrm{T}$ cells expressing 6B11 in ALL-patients compared with healthy controls $(6.03 \% \pm 5.25 \%$ vs. $2.69 \% \pm 2.17 \%, P<0.0102$, Fig. 3D). Furthermore, we found significantly** higher frequencies of $\mathrm{CD}^{+}$ $(7.27 \% \pm 11.04 \%$ vs. $0.31 \% \pm 0.38 \%, P<0.00745)$ and $\mathrm{CD} 161^{+}$ cells expressing $6 \mathrm{~B} 11(15.63 \% \pm 16.46 \%$ vs. $4.62 \% \pm 5.97 \%$, $P<0.0057$, Fig. 3D) and significantly* higher percentages of $\mathrm{CD} 8{ }^{+}$cells expressing 6B11 in ALL patients versus healthy controls $(1.28 \% \pm 1.44 \%$ vs. $0.59 \% \pm 1.12 \%, P<0.081)$.

In summary a shift to higher proportions of $\left(\mathrm{CD}^{+}\right.$ $\left.\mathrm{CD}^{+} / \mathrm{CD} 8{ }^{+}\right) \mathrm{T}$ cells and $\left(\mathrm{CD} 161^{+}\right) \mathrm{NK}$ cells coexpressing 6B11 was found in ALL-patients compared with healthy samples. However, unlike in AML-patients, lower frequencies of $\mathrm{CD}^{+}{ }^{+} \mathrm{CD} 161^{+} \mathrm{CIK}$ cells were found in the $\mathrm{CD} 3{ }^{+} \mathrm{T}$-cell fraction of ALL-patients versus in the healthy $\mathrm{CD} 3{ }^{+} \mathrm{T}$-cell fraction.

Adult ALL-Patients With Prognostically Favorable Subgroups are Characterized by Higher Proportions of iNKT and NK Cells

The ALL-patients' cohort included children and adults. As only 1 child relapsed only adult ALL-patients (treated with GMALL-therapy) were included in prognostic analyses.

Adult ALL-patients who achieved a CR after GMALLinduction chemotherapy were characterized by (ns) higher frequencies of $\mathrm{CD}_{3}{ }^{-} \mathrm{CD} 161^{+} \mathrm{NK}$ cells in $\mathrm{MNC}$ fractions than ALL-patients who achieved without CR $(1.09 \% \pm 1.48 \%$ vs. $0.18 \% \pm 0.11 \%$, dns). Moreover, we found (ns) higher percentages of $6 \mathrm{~B} 11^{+}, 6 \mathrm{~B} 11^{+} \mathrm{CD} 3{ }^{+}$, and $6 \mathrm{~B} 11^{+} \mathrm{V} \alpha 24^{+}$iNKT cells in the MNC-fraction of ALL-patients who achieved CR versus NCR $(0.95 \% \pm 1.02 \%$ vs. $0.65 \% \pm 0.37 \% ; 0.61 \% \pm 0.34 \%$ vs. $0.58 \% \pm 0.26 \% ; 0.16 \% \pm 0.30 \%$ vs. $0.03 \% \pm 0.05 \%$, dns). No differences were found for CIK cells.

Adult ALL-patients without extramedullary foci compared with those with extramedullary foci presented with (ns) higher proportions of $6 \mathrm{~B} 11^{+}, 6 \mathrm{~B} 11^{+} \mathrm{CD} 3{ }^{+}$, and $6 \mathrm{~B} 11^{+} \mathrm{V} \alpha 24^{+}$iNKT cells in the MNC fraction $(1.12 \% \pm 1.07 \%$ vs. $0.54 \% \pm 0.30 \% ; 0.63 \% \pm 0.38 \%$ vs. $0.56 \% \pm 0.21 \% ; 0.20 \pm 0.32 \%$ vs. $0.02 \% \pm 0.02 \%$, dns $)$. No differences were found for NK and CIK cells.

Although only few data were available we can demonstrate, that higher proportions of $6 \mathrm{~B} 11^{+} / 6 \mathrm{~B} 11^{+} \mathrm{CD} 3{ }^{+}$ $6 \mathrm{~B} 11^{+} \mathrm{V} \alpha 24^{+}$iNKT cells correlate with adult ALL-patients who achieved CR and without extramedullary foci. Moreover, CD ${ }^{-} \mathrm{CD} 161^{+}$NK cells correlated with adult ALL-patients who achieved CR. no correlations were found for CIK cells.

\section{Frequencies and Subtypes of iNKT, NK, and CIK Cells From CLL Patients Compared With Healthy Controls and Correlations With Prognosis}

CLL-Patients Show Significantly Lower Proportions of iNKT, NK, and CIK Cells in MNC Compared With Healthy MNC

We found significantly*** lower frequencies of $\mathrm{CD}^{+}$ CD56 ${ }^{+}$CIK cells in MNC of CLL-patients compared with healthy $\mathrm{MNC}(0.67 \% \pm 0.73 \%$ vs. $2.74 \% \pm 1.64 \%$, 
A CIK-cell-frequencies in MNC

$\mathrm{CD3}^{+} \mathrm{CD56}^{+} / \mathrm{MNC}$

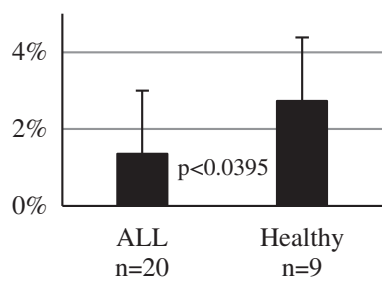

$B$ NK-cell-frequencies in MNC $\mathrm{CD3}^{-\mathrm{CD}^{+}}+\mathrm{MNC}$

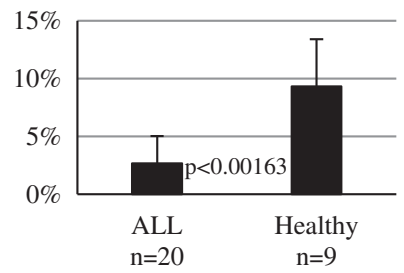

$\mathrm{CD3}^{+}{ }^{+} \mathrm{CD161}+\mathrm{MNC}$

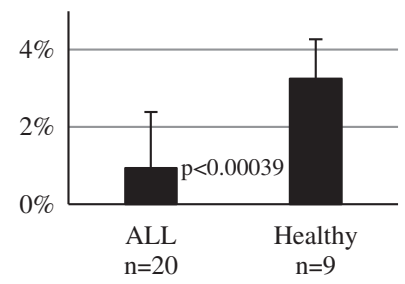

CD3-CD161+/MNC

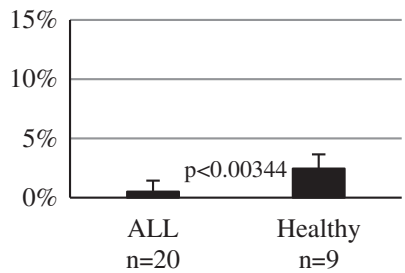

C iNKT-cell-frequencies in MNC

$6 \mathrm{~B} 11^{+} / \mathrm{MNC}$

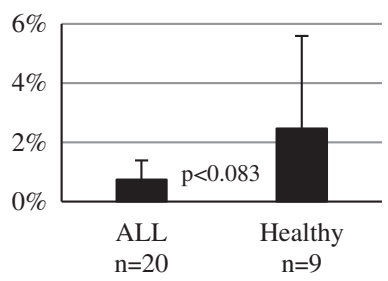

$6 \mathrm{B11}^{+} \mathrm{CD3}^{+} / \mathrm{MNC}$

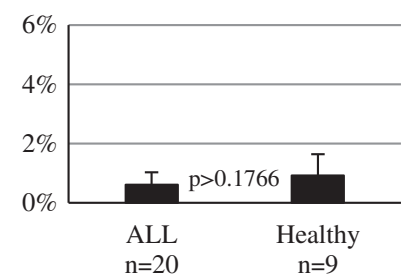

$6 \mathrm{B11}+{ }^{+} \mathrm{CD} 161^{+} / \mathrm{MNC}$

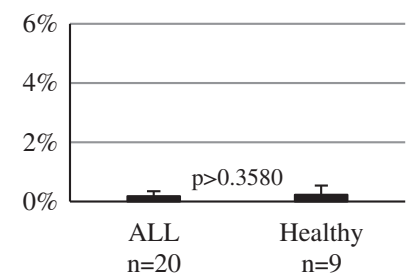

D iNKT-cell-subsetsin T-/NK-cell-fraction

$6 \mathrm{~B} 11^{+} \mathrm{CD3}^{+} / \mathrm{CD3}^{+}$

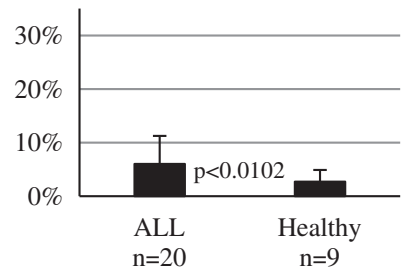

$6 \mathrm{~B} 11^{+} \mathrm{CD} 161^{+} / \mathrm{CD} 161^{+}$

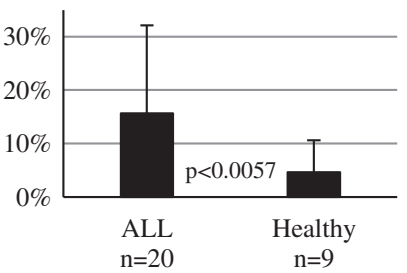

FIGURE 3. Frequencies of CIK, NK and iNKT cells and their subsets in healthy versus ALL MNC are given. Percentages of CIK cells $\left(\mathrm{CD} 3{ }^{+} \mathrm{CD} 56^{+} / \mathrm{MNC}\right.$ and $\left.\mathrm{CD} 3^{+} \mathrm{CD} 161^{+} / \mathrm{MNC}\right)(\mathrm{A})$, NK cells (CD3 - CD56 ${ }^{+} / \mathrm{MNC}$ and $\left.\mathrm{CD} 3-\mathrm{CD} 161^{+} / \mathrm{MNC}\right)(\mathrm{B})$, iNKT cells in MNC $\left(6 \mathrm{~B} 11^{+}, 6 \mathrm{~B} 11^{+} \mathrm{CD} 3^{+} / \mathrm{MNC}, 6 \mathrm{~B} 11^{+} \mathrm{CD} 161^{+} / \mathrm{MNC}\right)(\mathrm{C})$, and iNKT cell subsets in the $\mathrm{T}$ cell fraction $\left(6 \mathrm{~B} 11^{+} \mathrm{CD}^{+} / \mathrm{CD}^{+}\right)$and in the NK cell fraction $\left(6 \mathrm{~B} 11^{+} \mathrm{CD} 161^{+} / \mathrm{CD} 161^{+}\right)(\mathrm{D})$ are given. ALL indicates acute lymphoid leukemia; CIK, cytokine-induced killer; MNC, mononuclear cells; NK, natural killer; iNKT, invariant natural killer T.

$P<0.0036)$ and significantly*** lower frequencies of CD3 + CD161 + CIK cells $(0.67 \% \pm 0.84 \%$ vs. $3.25 \% \pm 1.02 \%$, $P<0.000168$, Fig. 4A). Moreover, we found significantly*** lower proportions of $\mathrm{CD}^{-} \mathrm{CD}^{-} 6^{+} \mathrm{NK}$ cells $(3.27 \% \pm 3.26 \%$ vs. $9.33 \% \pm 4.06 \%, P<0.00243)$ and significantly*** lower proportions of $\mathrm{CD}^{-}{ }^{-\mathrm{CD} 161}{ }^{+} \mathrm{NK}$ cells in MNC of CLL-patients versus healthy $\mathrm{MNC}(0.45 \% \pm 0.48 \%$ vs. $2.44 \% \pm 1.20 \%$, $P<0.00302$, Fig. 4B). Moreover, we found significant* lower frequencies of $6 \mathrm{~B} 11^{+}(0.78 \% \pm 0.47 \%$ vs. $2.47 \% \pm 3.12 \%$, $P<0.0828), 6 \mathrm{~B} 11^{+} \mathrm{CD} 3{ }^{+}(0.46 \% \pm 0.47 \%$ vs. $0.93 \% \pm 0.72 \%$, $P<0.072$, Fig. 4C) and $6 \mathrm{~B} 11^{+} \mathrm{V} \alpha 24^{+}$iNKT cells in MNC of CLL patients versus healthy MNC $(0.03 \% \pm 0.03 \%$ vs. $0.16 \% \pm 0.27 \%, P<0.09522$ ). Moreover, lower proportions of
$6 \mathrm{~B} 11^{+} \mathrm{CD}^{+}$and $6 \mathrm{~B} 11^{+} \mathrm{CD} 161{ }^{+}$iNKT cells were found in $\mathrm{MNC}$ from CLL patients versus healthy MNC (dns).

In summary frequencies of $6 \mathrm{~B} 11^{+} / 6 \mathrm{~B} 11^{+} \mathrm{CD} 3{ }^{+} / 6 \mathrm{~B} 11^{+}$ $\mathrm{CD}_{161}{ }^{+} / 6 \mathrm{~B} 11^{+} \mathrm{CD}{ }^{+} / 6 \mathrm{~B} 11^{+} \mathrm{V} \alpha 24^{+}{ }^{\mathrm{iNKT}}, \mathrm{CD} 3-\mathrm{CD} 56^{+} /$ $\mathrm{CD}^{-}{ }^{-} \mathrm{CD} 161^{+} \mathrm{NK}$ and $\mathrm{CD} 3{ }^{+} \mathrm{CD} 56^{+} / \mathrm{CD} 3{ }^{+} \mathrm{CD} 161^{+} \mathrm{CIK}$ cells/subsets were (significantly) lower in CLL MNC than in healthy MNC.

\section{Significantly Higher Proportions of T and NK Cells Express 6B11 in CLL-Patients Compared With Healthy Controls}

We found significantly*** higher frequencies of $\mathrm{CD} 3^{+}$ $\mathrm{T}$ cells expressing 6B11 in CLL-patients compared with 
healthy controls $(11.27 \% \pm 11.83 \%$ vs. $2.69 \% \pm 2.17 \%$, $P<0.00384$, Fig. 4D). Furthermore, we found significantly** higher frequencies of for $\mathrm{CD}^{+}$cells expressing 6B11 $(7.14 \% \pm 5.90 \% \quad$ vs. $0.31 \% \pm 0.38 \%, \quad P<0.00908) \quad$ and significantly*** higher frequencies of $\mathrm{CD} 161^{+}$cells expressing 6B11 in CLL-patients versus healthy controls $(23.55 \% \pm 20.47 \%$ vs. $4.62 \% \pm 5.97 \%, P<0.00043$, Fig. $4 \mathrm{D})$. We did not find significant differences in the numbers of $\mathrm{CD} 3{ }^{+} \mathrm{CD} 161^{+} \mathrm{CIK}$ cells in the $\mathrm{CD} 3{ }^{+} \mathrm{T}$ cell fraction and CD8 ${ }^{+} \mathrm{T}$ cells expressing 6B11 (dns).

In summary a shift to higher proportions of $\left(\mathrm{CD} 3^{+} /\right.$ $\left.\mathrm{CD}^{+}{ }^{+}\right) \mathrm{T}_{\text {cells and }}\left(\mathrm{CD} 161^{+}\right) \mathrm{NK}$ cells coexpressing 6B11 was found in CLL-patients compared with healthy samples. Like in AML patients, but unlike in ALL patients, no differences were found for CIK cells in the $\mathrm{CD} 3^{+}$T-cell fraction. Unlike AML and ALL patients no differences were found for $\mathrm{CD} 8{ }^{+} \mathrm{T}$ cells expressing $6 \mathrm{~B} 11$.

\section{CLL-Patients With Prognostically Favorable Subgroups are Characterized by Higher Proportions of iNKT, NK, and CIK Cells}

CLL-patients with no need versus need for therapy presented with significantly* higher proportions of $\mathrm{CD} 3^{+}$ $\mathrm{CD}^{2} 6^{+} \mathrm{CIK}$ cells in the MNC fraction $(1.07 \% \pm 1.03 \%$ vs. $0.43 \% \pm 0.28 \%, P<0.093$; Fig. 5.2A, left side). We found (ns) higher frequencies of $6 \mathrm{~B} 11^{+} \mathrm{iNKT}$ cells in the MNC fraction of CLL patients with no need versus need for therapy $(0.81 \% \pm 0.50 \%$ vs. $0.73 \% \pm 0.40 \%$; Fig. $5.2 \mathrm{~A}$, middle row). Comparable results were found for $6 \mathrm{~B} 11{ }^{+} \mathrm{CD}^{+}$and $6 \mathrm{~B} 11^{+} \mathrm{V} \alpha 24^{+}$iNKT cell proportions in the MNC fraction

A CIK-cell-frequencies in MNC

$\mathrm{CD3}^{+} \mathrm{CD56}^{+} / \mathrm{MNC}$

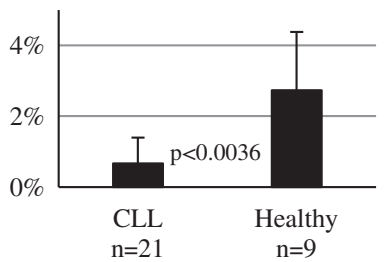

$B$ NK-cell-frequencies in MNC $\mathrm{CD3}^{-\mathrm{CD}^{-}}{ }^{+} / \mathrm{MNC}$

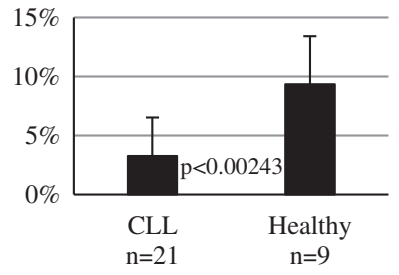

\section{$\mathrm{CD3}^{+}{ }^{+} \mathrm{CD} 161^{+} / \mathrm{MNC}$}

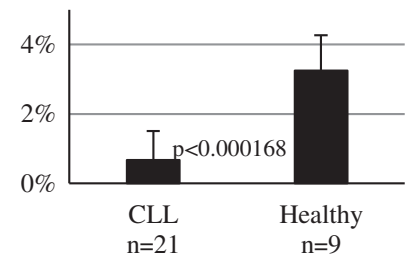

$\mathrm{CD3}^{-\mathrm{CD}^{-161}}{ }^{+} / \mathrm{MNC}$

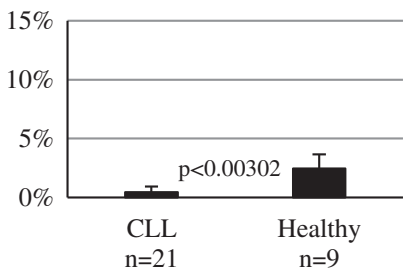

C iNKT-cell-frequencies in MNC

6B11 + MNC

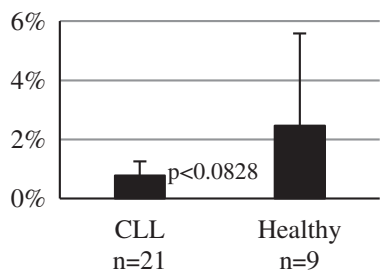

$6 \mathrm{B11}^{+} \mathrm{CD3}^{+} / \mathrm{MNC}$

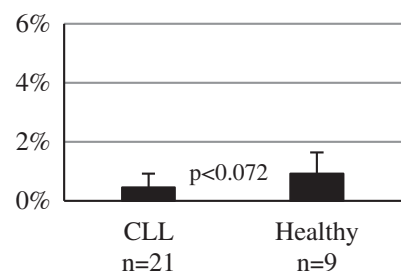

$6 \mathrm{~B} 11^{+} \mathrm{V} \alpha 24^{+} / \mathrm{MNC}$

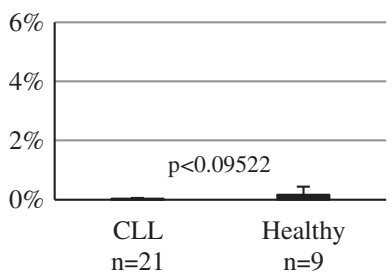

D iNKT-cell-subsets in T-/NK-cell-fraction

${ }^{6 B_{11}}{ }^{+} \mathrm{CD3}^{+} / \mathrm{CD3}^{+}$

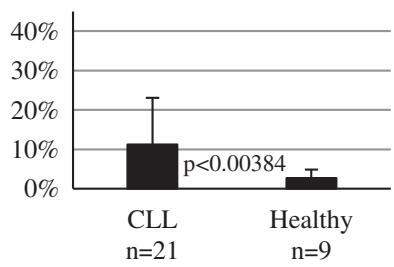

$6 B 11^{+} \mathrm{CD}^{261}{ }^{+} / \mathrm{CD} 161^{+}$

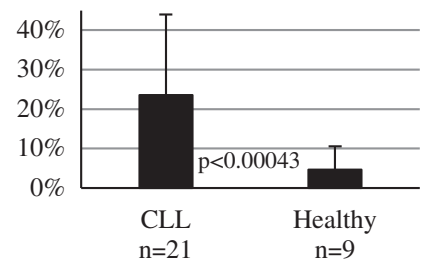

FIGURE 4. Frequencies of CIK, NK, and iNKT cells and their subsets in healthy versus CLL MNC are given. Percentages of CIK cells $\left(\mathrm{CD} 3{ }^{+} \mathrm{CD} 56^{+} / \mathrm{MNC}\right.$ and $\left.\mathrm{CD} 3^{+} \mathrm{CD} 161^{+} / \mathrm{MNC}\right)(\mathrm{A})$, NK cells (CD3 - CD56 + MNC and CD3 - CD161 + /MNC) (B), iNKT cells in MNC $\left(6 \mathrm{~B} 11^{+}, 6 \mathrm{~B} 11^{+} \mathrm{CD} 3^{+} / \mathrm{MNC}, 6 \mathrm{~B} 11^{+} \mathrm{V} \alpha 24^{+} / \mathrm{MNC}\right)(\mathrm{C})$, and iNKT cell subsets in the T-cell fraction $\left(6 \mathrm{~B} 11^{+} \mathrm{CD} 3^{+} / \mathrm{CD}^{+}\right)$and in the NK cell fraction $\left(6 \mathrm{~B} 11^{+} \mathrm{CD} 161^{+} / \mathrm{CD} 161^{+}\right)(\mathrm{D})$ are given. CIK indicates cytokine-induced killer; CLL, chronic lymphoid leukemia; MNC, mononuclear cells; NK, natural killer; iNKT, invariant natural killer T. 
of CLL patients with no need versus need for therapy (dns). No differences were found for NK cells.

CLL-patients younger versus older than 60 years presented with significantly* higher frequencies of $6 \mathrm{~B} 11^{+}$ and $6 \mathrm{~B} 11^{+} \mathrm{V} \alpha 24^{+}$iNKT cells in the MNC fraction $(0.87 \% \pm 0.55 \%$ vs. $072 \% \pm 0.40 \% ; 0.04 \% \pm 0.03 \%$ vs. $0.01 \% \pm 0.01 \% ; P<0.0711$, Fig. 5.2A, right side).
CLL-patients with stable versus no stable disease (NCR, relapse or death with disease) presented with (ns) higher percentages of $\mathrm{CD} 3{ }^{+} \mathrm{CD} 56{ }^{+} \mathrm{CIK}$ cells and CD3 ${ }^{-} \mathrm{CD} 56^{+} \mathrm{NK}$ cells in MNC fraction $(0.70 \% \pm 0.79 \%$ vs. $0.47 \% \pm 0.23 \%$; $3.40 \% \pm 3.33 \%$ vs. $3.50 \% \pm 2.64 \%$, Fig. 5.2B, left side; middle row). Moreover, we could demonstrate significantly** higher frequencies of $6 \mathrm{~B} 11^{+}(0.82 \% \pm 0.49 \%$

\subsection{Prognostic relevance for AML-pts}

A Response to chemotherapy (CR vs NCR, left side), allocation to favorable vs adverse risk score ( $\mathrm{NCCN}$, middle row), allocation to age groups ( $<60 \mathrm{vs}>60$ years, right side)

$\mathrm{CD3}^{+} \mathrm{CD56}^{+} / \mathrm{MNC}$

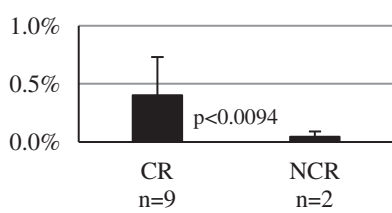

$6 \mathrm{~B} 11^{+} / \mathrm{MNC}$

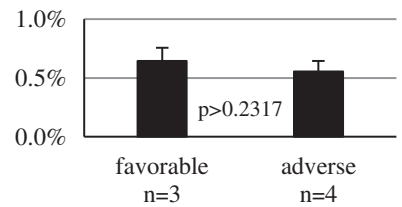

$6 \mathrm{~B} 11^{+} / \mathrm{MNC}$

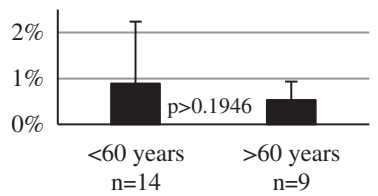

B Extramedullary vs no extramedullary foci

$\mathrm{CD3}^{+} \mathrm{CD56}^{+} / \mathrm{MNC}$

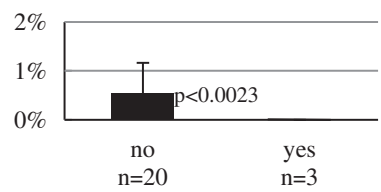

C Stable CR (yes or no) $\mathrm{CD3}^{+}{ }^{+} \mathrm{CD161}{ }^{+} / \mathrm{MNC}$

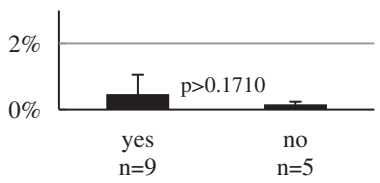

$\mathrm{CD3}^{-\mathrm{CD}^{6}}{ }^{+} / \mathrm{MNC}$

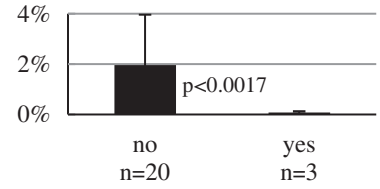

CD3-CD161+/MNC

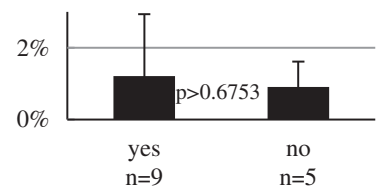

6B11 + MNC

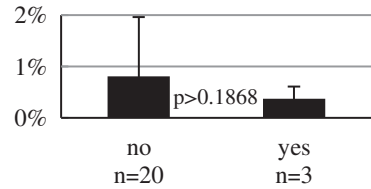

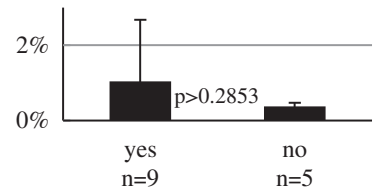

5.2. Prognostic relevance for CLL-pts

A Need for therapy (yes or no, left side + middle row), allocation to age groups $(<60 \mathrm{vs}$ $>60$ years, right side)

$\mathrm{CD3}^{+} \mathrm{CD56}^{+} / \mathrm{MNC}$

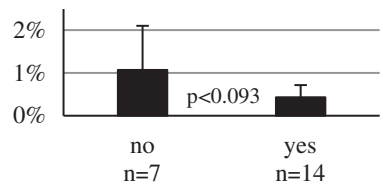

B Stable disease (yes or no)

$\mathrm{CD3}^{+} \mathrm{CD56}^{+} / \mathrm{MNC}$

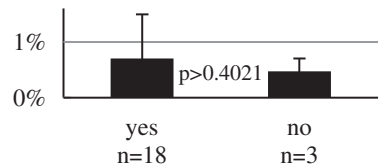

$6 \mathrm{~B} 11^{+} / \mathrm{MNC}$

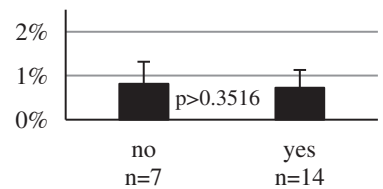

$\mathrm{CD3}^{-\mathrm{CD}^{2}}{ }^{+} / \mathrm{MNC}$

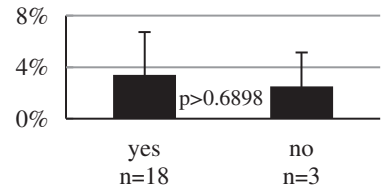

$6 \mathrm{~B}^{1} 1^{+} \mathrm{Va24}+/ \mathrm{MNC}$

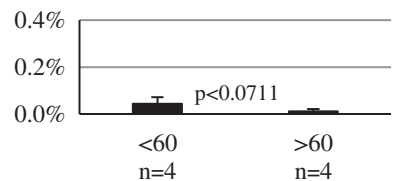

$6 \mathrm{~B} 11^{+} / \mathrm{MNC}$

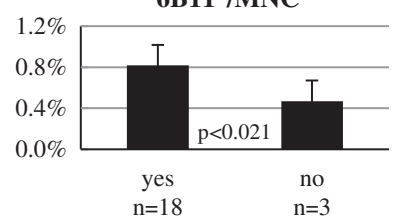

FIGURE 5. Relevance of CIK, NK, and iNKT cells and their subsets for prognosis of AML and CLL patients. 5.1. AML patients: Frequencies of CIK cells in patients with CR versus NCR after induction chemotherapy, iNKT cells in patients with favorable versus adverse risk score $(\mathrm{NCCN})$ and younger than 60 versus older than 60 years (A), CIK, NK, and iNKT cells in patients with extramedullary versus no extramedullary foci (B), and CIK, NK, and iNKT cells in patients with stable versus no stable disease are given (C). 5.2. CLL patients: frequencies of CIK and iNKT cells in patients with no need versus need for therapy, iNKT cells in patients younger than 60 versus older than 60 years (A) and CIK, NK, and iNKT cells in patients with stable versus no stable disease are given (B). AML indicates acute myeloid leukemia; CIK, cytokine-induced killer; CLL, chronic lymphoid leukemia; CR, complete remission; iNKT, invariant natural killer T; MNC, mononuclear cells; NCCN, National Comprehensive Cancer Network; NCR, no complete remission; NK, natural killer; pts, patients. 
vs. $0.47 \% \pm 0.06 \%, P<0.021$, Fig. 5.2B) and significantly* higher frequencies of $6 \mathrm{~B} 11^{+} \mathrm{CD} 3{ }^{+}$iNKT cells in the MNC fraction of CLL patients with stable CR versus NCR $(0.49 \% \pm 0.48 \%$ vs. $0.17 \% \pm 0.09 \%, P<0.0597$ right side $)$.

In summary (significantly) higher proportions of $6 \mathrm{~B} 11^{+}$iNKT cells correlated with no need for therapy, CLL patients younger than 60 years and stable CR. Comparable correlations were found for $6 \mathrm{~B} 11^{+} \mathrm{CD} 3{ }^{+} /$ $6 \mathrm{~B} 11^{+} \mathrm{V} \alpha 24^{+}$iNKT subsets. CD ${ }^{-} \mathrm{CD} 56^{+} \mathrm{NK}$ and $\mathrm{CD}^{+}{ }^{+} \mathrm{CD} 56^{+} \mathrm{CIK}$ cells regularly correlated with stable $\mathrm{CR}$, while only $\mathrm{CD} 3^{-} \mathrm{CD} 56^{+} \mathrm{NK}$ cells correlated with no need for therapy.

\section{iNKT, NK, and CIK Cells and their Subtypes Increase Under the Influence of IL-2 and After Prestimulation With $\mathrm{DC} / \mathrm{DC}_{\mathrm{leu}}$}

It is well known, that $\mathrm{DC} / \mathrm{DC}_{\text {leu }}$ are professional stimulators of $\mathrm{T}$ cells, thereby giving rise to antileukemic active effector cells after MLC (containing IL-2).

We generated $\mathrm{DC} / \mathrm{DC}_{\text {leu }}$ from healthy or leukemic $\mathrm{MNC}$ or $\mathrm{WB}\left(\mathrm{DC}_{\text {leu }}\right.$ were only analyzed in cases where the amount of DC were $\geq 10 \%$ ) and achieved the following results.

\section{"MNC-Healthy" \\ With "Kit-D" we generated $\varnothing 10.79 \% \pm 2.07 \%$, with "Pici 1" $15.42 \% \pm 4.97 \%$ and with "Pici 2" $15.33 \% \pm 6.09 \%$ DC in MNC.}

\section{"WB-Healthy"}

With "Kit-D" we generated $\varnothing 7.44 \% \pm 1.28 \%$, with "Kit-I" $11.05 \% \pm 6.82 \%$, with "Kit-K" $8.62 \% \pm 2.00 \%$, with "Kit-M" $8.08 \% \pm 3.38 \%$, with "Pici $1 "$ $10.50 \% \pm 2.62 \%$ and with "Pici $2 " 9.48 \% \pm 1.85 \%$ DC in WB.

\section{"MNC-AML"}

With "Kit-D" we generated Ø $36.51 \% \pm 7.33 \%$ DC and $6.70 \% \pm 0.58 \% \mathrm{DC}_{\text {leu }}$, with "Pici 1 " $23.53 \% \pm 0.00 \%$ $\mathrm{DC}$ and $12.63 \% \pm 0.00 \% \quad \mathrm{DC}_{\text {leu }}$ and with "Pici 2" $19.39 \% \pm 7.39 \% \quad$ DC and $10.20 \% \pm 0.00 \% \quad \mathrm{DC}_{\text {leu }}$ in MNC.

\section{"WB-AML"}

With "Kit-D" we generated $\varnothing 6.85 \% \pm 1.10 \%$ DC, with "Kit-I" $13.18 \% \pm 7.43 \%$ DC and $19.95 \% \pm 0.00 \%$ $\mathrm{DC}_{\text {leu }}$, with "Kit-K" $10.48 \% \pm 3.77 \% \quad \mathrm{DC}$ and $8.11 \% \pm 2.38 \% \mathrm{DC}_{\text {leu }}$, with "Kit-M" $9.92 \% \pm 3.93 \% \mathrm{DC}$ and $13.62 \% \pm 0.00 \% \quad \mathrm{DC}_{\text {leu }}$, with "Pici 1 " $10.16 \% \pm 0.00 \%$ DC and $8.98 \% \pm 0.00 \% \mathrm{DC}_{\text {leu }}$ and with "Pici $2 " 12.88 \% \pm 0.00 \%$ DC and $11.39 \% \pm 0.00 \% \mathrm{DC}_{\text {leu }}$ in WB.

Pooling all results from the controls without added response modifiers ("MNC-healthy," "WB-healthy," "MNCAML," "WB-AML") we found Ø 6.28\% $\pm 2.09 \%$ DC.

Here we studied, whether iNKT/NK/CIK cells (in MNC or WB samples) could contribute to improve the overall antileukemic activity after stimulation with $\mathrm{DC} /$ $\mathrm{DC}_{\text {leu. }}$. Therefore, we stimulated in MLC (prepared with MNC or WB) T-cell-enriched immune reactive cells with a stimulator cell suspension containing $\mathrm{DC} / \mathrm{DC}_{\text {leu }}$ (MLC*"MNC-DC" or MLC*"WB-DC") which were generated with different "cocktails." The same setting, but with a stimulator cell suspension without pretreatment with "cocktails" (MLC*“MNC" or MLC*"WB") served as a control. First, we quantified these cells before and after MLC with added $T$ cells and IL-2. In a second step, we analyzed the effect of different "cocktail"-generated $\mathrm{DC} / \mathrm{DC}_{\text {leu }}$ on the composition of immune reactive cells after stimulation. Further, we correlated our findings with antileukemic reactivity in a context with iNKT, NK, CIK cells, and T-cell subsets.

\section{In MLC of Healthy and AML-Patients (MLC*"WB-DC" or only MLC*“WB") Proportions of iNKT/NK and CIK Cells Increase in the Presence of IL-2}

At start of MLC we found lower total frequencies of iNKT cells and a shift to higher proportions of $\mathrm{T} / \mathrm{NK}$ cells coexpressing $6 \mathrm{~B} 11$ in $\mathrm{AML}$ patients $(\mathrm{n}=6)$ versus healthy $\mathrm{WB}$ samples $(n=5$; Fig. $6 \mathrm{~A})$. In a next step we quantified these cells after MLC and found that iNKT cells significantly(*)* increased in both AML and healthy WB-samples after MLC: at start of MLC versus after MLC*"WB"(AML 6B11 + $/$ MLC: $4.18 \% \pm 1.32 \%$ vs. $8.63 \% \pm 4.40 \%, P<0.0745^{*}$; healthy $6 \mathrm{~B} 11^{+}$ MLC: $4.68 \% \pm 3.92 \%$ vs. $12.34 \% \pm 8.10 \%, P<0.0305^{* * *}$; healthy $6 \mathrm{~B} 11^{+} \mathrm{CD} 3{ }^{+} / \mathrm{MLC}: \quad 4.60 \% \pm 3.90 \% \quad$ vs. $\quad 12.11 \% \pm 8.10 \%$, $P<0.0385^{* *}$; healthy $6 \mathrm{~B} 11^{+} \mathrm{CD} 3{ }^{+} / \mathrm{CD}^{+}: 5.17 \% \pm 4.63 \%$ vs. $31.77 \% \pm 22.85 \%, P<0.0732 \%$; Figs. 6 A, B) and start of MLC versus after MLC*“WB-DC" (healthy 6B11 ${ }^{+}$/MLC: $4.68 \% \pm 3.92 \%$ vs. $13.67 \% \pm 5.01 \%, P<0.0323^{* *}$; healthy $6 \mathrm{~B} 11^{+} \mathrm{CD} 3^{+}$/MLC: $4.60 \% \pm 3.90 \%$ vs. $13.03 \% \pm 4.91 \%, \quad P<0.0393 * * ; \quad 6 \mathrm{~B} 11^{+}$ $\mathrm{CD}^{+} / \mathrm{CD}^{+}: \quad 5.17 \% \pm 4.63 \%$ vs. $21.51 \% \pm 7.38 \%$, $P<0.0093^{* *}$, Fig.s 6A, C).

Pooling all results after MLC*"WB-DC" compared with MLC*"WB", an astonishing finding was, that cellular compositions in healthy samples were comparable in both settings (Figs. 6B, C). This could be due to the general influence of IL-2 in MLC. However, in AML-cases the proportions of iNKT cells increased after MLC*"WB-DC" compared with MLC*"WB" (Figs. 6B, C), although differences were not significant. Comparable results were found with MNC as cell sources (dns).

At start of MLC we found lower total frequencies of CIK and NK cells in AML $(n=6)$ versus healthy WB-samples $(n=5)$ (Fig. 7A). In a next step we quantified these cells after MLC and found that CIK and NK cells (significantly) increased in both AML and healthy WB-samples after MLC: at start of MLC versus after MLC*"WB"(AML CD3 ${ }^{+}$CD161 ${ }^{+}$/MLC: $1.41 \% \pm 0.74 \%$ vs. $3.28 \% \pm 1.59 \%, P<0.0487 * *$; healthy CD $3{ }^{+}$CD161 ${ }^{+} / \mathrm{MLC}$ : $2.35 \% \pm 2.59 \%$ vs. $3.30 \% \pm 2.04 \%$; $\mathrm{AML} \mathrm{CD}^{-} \mathrm{CD}^{-} 61^{+}$ MLC: $0.15 \% \pm 0.15 \%$ vs. $1.62 \% \pm 1.81 \%$; healthy $\mathrm{CD}^{-}$ CD161 ${ }^{+}$/MLC: $1.41 \% \pm 2.48 \%$ vs. $0.80 \% \pm 0.86 \%$; Figs. $7 \mathrm{~A}$, B) and start of MLC versus after MLC*"WB-DC" (AML $\mathrm{CD} 3{ }^{+} \mathrm{CD}_{161}{ }^{+}$/MLC: $1.41 \% \pm 0.74 \%$ vs. $3.15 \% \pm 2.13 \%$; healthy $\quad \mathrm{CD}^{+}{ }^{+} \mathrm{CD} 161{ }^{+} / \mathrm{MLC}: \quad 2.35 \% \pm 2.59 \% \quad$ vs. $4.20 \% \pm 2.02 \%$; AML CD3 ${ }^{-} \mathrm{CD} 161^{+} / \mathrm{MLC}: 0.15 \% \pm 0.15 \%$ vs. $1.73 \% \pm 1.98 \%$; healthy $\mathrm{CD}^{-}{ }^{-} \mathrm{CD} 161^{+} / \mathrm{MLC}$ : $\mathrm{AML}$ $1.41 \% \pm 2.48 \%$ vs. $0.57 \% \pm 0.37 \%$; Figs. $7 \mathrm{~A}, \mathrm{C}$ ).

Pooling all results after MLC*"WB-DC" compared with MLC*"WB", an astonishing finding was, that cellular compositions in healthy samples were comparable in both settings (Figs. 7B, C). This could be due to the general influence of IL-2 in MLC.

Moreover, we determined values of IL-10, IL-17A, IFN- $\gamma$ and MCP-1 after MLC*"WB-DC", MLC*"WB", WBDC culture and WB-DC control in the supernatant of samples from AML patients $(n=4)$ using ELISA. An increased cytokine release was shown for IL-17A, MCP-1 
A
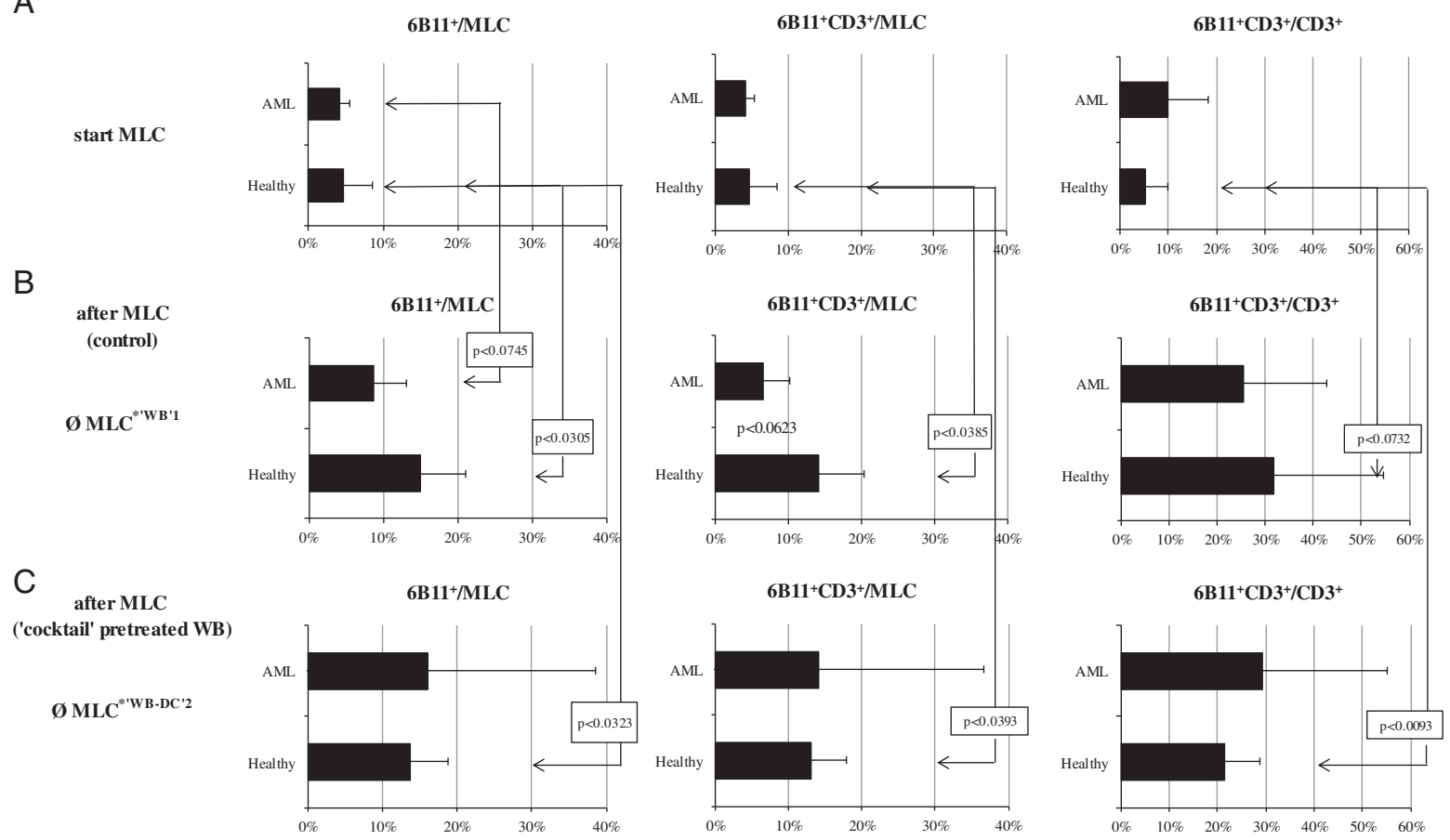

FIGURE 6. Frequencies of iNKT cells before $(A)$ or after $(B, C) M L C(W B)$ are given. T cell-enriched immune reactive cells were stimulated with a stimulator cell suspension without pretreatment of WB (MLC*“WB"1 (control)) (B) or with a stimulator cell suspension pretreated with "cocktails" (MLC*“WB-DC"2) (C). "MLC*"WB" T-cell enriched immune-reactive cells were stimulated with a stimulator cell suspension without pretreatment of WB with "cocktails". ${ }^{2} \mathrm{MLC} *$ "WB-DC" T-cell-enriched immune-reactive cells were stimulated with a stimulator cell suspension pretreated with "cocktails," "cocktails" = all DC-generating methods/Kits. DC indicates dendritic cells; iNKT, invariant natural killer T; MLC, mixed lymphocyte cultures; WB, whole blood.

and IL-10 in WB-DC supernatants compared with WB-DC control - what correlated with higher DC counts compared with control. An increased release of the chemoattractant MCP-1 was found after MLC*"WB-DC" with all DCgenerating methods/Kits compared with MLC*“"WB". An increased antitumor and anti-inflammatory cytokine profile (IL-17A and IL-10) was found after MLC*"WB-DC" especially with Kit-M pretreated WB (dns) compared with MLC*"WB".

In summary iNKT as well as CIK and NK cells increased after MLC independent of the stimulator cell suspension, what might be explained by a general iNKT, NK, and CIK cells inducing effect by IL-2. AML samples treated with "cocktails" and used as stimulator cells seemed to increase iNKT but not CIK and NK cell counts compared with not pretreated controls, pointing to an "iNKTinducing influence" of these different "cocktails."

\section{Highest iNKT Frequencies After MLC Could be Found in Cases With DC Generation Conducted With Prostaglandin-containing "Cocktails"}

Studying the influence of different $\mathrm{DC} / \mathrm{DC}_{\text {leu }}$, generated with "cocktails," on the frequencies of $6 \mathrm{~B} 11{ }^{+}$iNKT cells after MLC showed, that in MNC/WB samples iNKT cell proportions increased in general during the MLC. For each individual patient we defined the best stimulator cell source resulting in the "highest" $(+++) 6 \mathrm{~B} 11^{+}$ iNKT cell frequencies after MLC $\left(\varnothing 6 \mathrm{~B} 11^{+} / \mathrm{WB}\right.$ : $\left.24.91 \% \pm 19.61 \%, \quad \varnothing 6 \mathrm{~B} 11^{+} / \mathrm{MNC}: \quad 10.98 \% \pm 7.05 \%\right)$; in "high" $(++) 6 \mathrm{~B} 11^{+}$iNKT cell frequencies (only defined for $\mathrm{WB}, \varnothing 6 \mathrm{~B} 11^{+} / \mathrm{WB}$ : $\left.13.56 \% \pm 6.59\right)$; with a "good" $(+)$ frequency of $6 \mathrm{~B} 11^{+}$iNKT cells $\left(\varnothing 6 \mathrm{~B} 11^{+} /\right.$ WB: $8.06 \% \pm 2.77 \% ; \varnothing 6 \mathrm{~B} 11^{+} / \mathrm{MNC}: 5.88 \% \pm 4.42 \%$ ) and with "no increase" $(-)$ or even in a decrease of iNKT cells $\left(\varnothing 6 \mathrm{~B} 11^{+} / \mathrm{WB}: \quad 3.94 \% \pm 2.45 \%, \quad \varnothing 6 \mathrm{~B} 11^{+} / \mathrm{MNC}\right.$ : $0.93 \% \pm 0.21 \%)$. Frequencies were applied for healthy and AML samples.

Similar distributions were found for $6 \mathrm{~B} 11^{+} \mathrm{CD} 161^{+}$ and $6 \mathrm{~B} 11^{+} \mathrm{CD} 3{ }^{+}$iNKT cells. We could show that especially in cases in that the DC generation was performed with prostaglandin-containing $\left(\mathrm{PGE}_{1}, \mathrm{PGE}_{2}\right)$ "cocktails" the percentages of iNKT cells increased the most (Kit-D, Kit-K, Kit-M, "Pici1," "Pici2," Fig. 8.1) Moreover, we found that in almost every given patient (except P1433) we could select at least one of several "cocktails," that increased iNKT proportions - pointing to an effect of a certain pretreatment with "cocktails" on the frequencies of iNKT cells in healthy as well as of AML samples. Effects seen in $\mathrm{MNC}$ and WB samples from healthy and AML samples were comparable (Figs. 8.1A, B). Comparable effects were found for CIK cells (dns).

Moreover, we correlated percentages of $6 \mathrm{~B} 11^{+} /$ $6 \mathrm{~B} 11^{+} \mathrm{CD} 3{ }^{+} / 6 \mathrm{~B} 11^{+} \mathrm{CD} 161^{+}$iNKT cells (defined as "highest," "high," "good," and "no increase") after MLC in MNC (Fig. 7.1A, healthy "MNC") for each individual sample with the frequencies of DC after culture of healthy MNC $(n=8)$ with different "cocktails." We found that samples with the "highest" (Ø6B11+/MNC: $10.98 \% \pm 7.05 \%$ ) frequencies of iNKT cells showed (although not significant) higher percentages of DC after the DC-generating process compared with MLC with "no increase" (Ø6B11+/MNC: $0.93 \% \pm 0.21 \%)$ or even a 
A

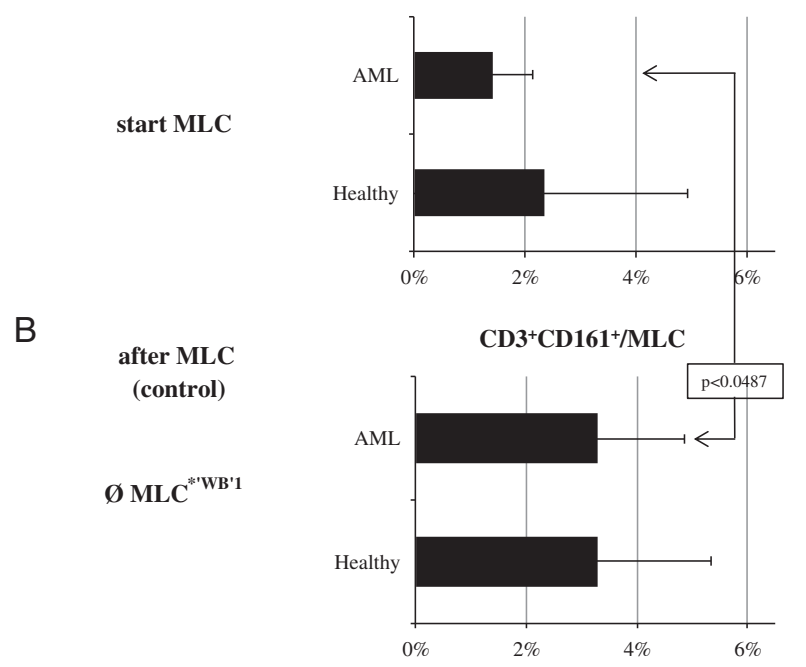

C

after MLC ('cocktail' pretreated WB) Ø MLC ${ }^{* \prime W B-D C ' 2}$
$\mathrm{CD}^{+}{ }^{+} \mathrm{CD}^{161+}{ }^{+} / \mathrm{MLC}$

$\mathrm{CD3}^{+}{ }^{+} \mathrm{D161}+\mathrm{MLC}$

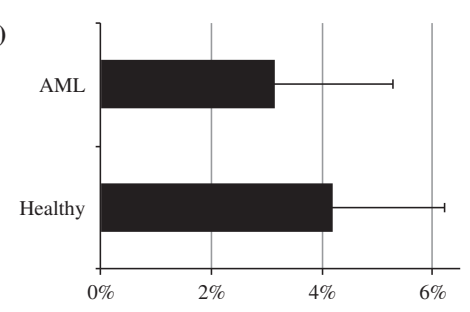

$\mathrm{CD3}^{-\mathrm{CD} 161^{+} / \mathrm{MLC}}$

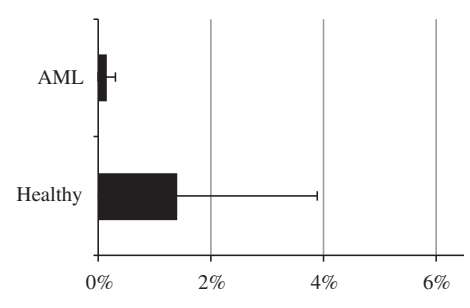

CD3-CD161+/MLC

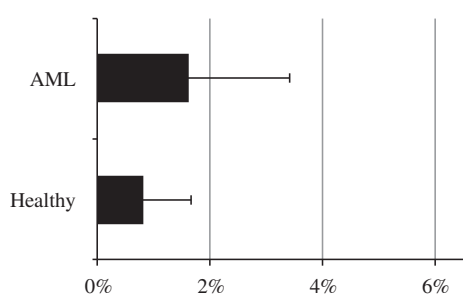

$\mathrm{CD3}^{-} \mathrm{CD}^{-161}+\mathrm{MLC}$

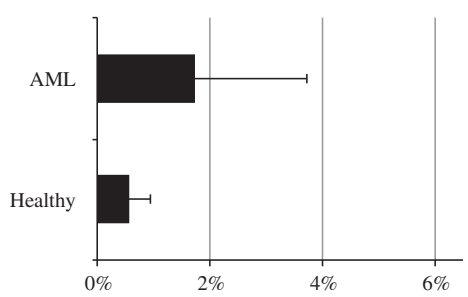

FIGURE 7. Frequencies of CIK/NK cells before (A) or after (B, C) MLC (WB) are given. T cell-enriched immune reactive cells were stimulated with a stimulator cell suspension without pretreatment of WB (MLC*“WB"1 (control)) (B) or with a stimulator cell suspension pretreated with "cocktails" (MLC*"WB-DC" 2$)(C) .{ }^{1} \mathrm{MLC}^{*}$ "WB" T-cell enriched immune reactive cells were stimulated with a stimulator cell suspension without pretreatment of WB with "cocktails." " ${ }^{2} \mathrm{MLC} *$ "WB-DC" T-cell enriched immune reactive cells were stimulated with a stimulator cell suspension pretreated with "cocktails." "Cocktails" = all DC-generating methods/Kits. CIK indicates cytokine-induced killer; DC, dendritic cells; MLC, mixed lymphocyte cultures; WB, whole blood.

decrease of iNKT cells (Ø DC-counts: $12.87 \% \pm 5.44 \%$ vs. $9.11 \% \pm 8.81 \%$; Fig. 8.2). Those correlations were not found for MNC of the 2 AML-patients we have analyzed (dns). In a next step, we correlated these values with $\mathrm{DC} /$ DC-subtype values obtained from 5 healthy and 6 AMLWB samples and did not find correlations between DC/DC subtype counts and iNKT cells after MLC (dns).

In summary, differences in iNKT cell compositions after MLC could be found in individual samples (healthy or AML) after pretreatment with different "cocktails." Highest percentages were found with prostaglandincontaining methods. Together, high frequencies of DC correlated with "highest" frequencies of iNKT cells after MLC in MNC of healthy controls, while lower percentages of DC correlated with "no increase" or even a decrease of iNKT cells after MLC in MNC of healthy controlshowever, these correlations were not found for the $2 \mathrm{AML}$ patients analyzed.

\section{Physiological Hypoxia Does Not Influence Frequencies and Compositions of iNKT, NK, and CIK Cells Compared With Normoxic Conditions}

Under physiological conditions the $\mathrm{O}_{2}$-concentration in $\mathrm{PB}$ is lower than the normoxic $21 \%$. With some preliminary experiments, we wanted to work out results under physiologically most adapted conditions in order to draw first conclusions for the functional relevance on immune-reactive cells: physiological low $\mathrm{O}_{2}$ concentrations could possibly influence the conversion of blasts to $\mathrm{DC}_{\text {leu }}$ and in consequence the composition and reactivity of immune-reactive cells. Here we studied whether hypoxic (compared with normoxic) conditions influence the composition of iNKT/NK/CIK cells after MLC (in WB samples). Results included in this chapter were cultured in $6 \%$ or $10 \% \mathrm{O}_{2}$ or with varying $\mathrm{O}_{2}$-concentrations between $0 \%$ and $17 \%$. For our evaluations, all results were pooled. In a first step, we quantified DC-(subtype) proportions in healthy WB samples $(n=4)$ with or without stimulation with 3 "cocktails" (Kit-I, Kit-K or Kit-M). We could show that $\mathrm{DC}$ proportions [overall and mature $\mathrm{DC}\left(\mathrm{DC}_{\mathrm{mig}}\right)$ ] were not significantly different in cases cultured under normoxic versus hypoxic conditions (dns).

In a next step, we quantified iNKT/NK/CIK cell proportions after MLC*"WB-DC" and MLC*“WB" under hypoxic versus normoxic conditions. Pooling all results after MLC*"WB-DC" we found comparable proportions of iNKT/NK/CIK cells after MLC under normoxic versus hypoxic conditions (dns).

In summary low $\mathrm{O}_{2}$ culture concentrations do not seem to have neither a significant effect on the generation of DC nor on the amount and composition of iNKT, NK, and CIK cells after MLC. 
8.1. Frequencies of iNKT-cells (subsets) after MLC

\begin{tabular}{|c|c|c|c|c|c|c|c|}
\hline \multicolumn{8}{|c|}{ 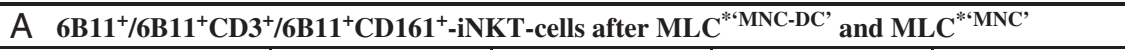 } \\
\hline Healthy 'MNC' & \multicolumn{2}{|c|}{ Kit-D } & \multicolumn{2}{|c|}{\begin{tabular}{l|l} 
'Pici1' & \\
\end{tabular}} & 'Pici2' & \multicolumn{2}{|c|}{ control } \\
\hline P1418 & \multicolumn{2}{|c|}{+} & \multicolumn{2}{|c|}{+++} & - & \multicolumn{2}{|r|}{+} \\
\hline P1421 & \multicolumn{2}{|c|}{+} & \multicolumn{2}{|c|}{+} & +++ & \multicolumn{2}{|r|}{+} \\
\hline P1422 & \multicolumn{2}{|c|}{+} & \multicolumn{2}{|c|}{+++} & + & \multicolumn{2}{|r|}{+} \\
\hline P1425 & \multicolumn{2}{|c|}{+++} & & & & \multicolumn{2}{|r|}{+} \\
\hline \multirow{2}{*}{$\begin{array}{l}\text { P1428 } \\
\text { P1429 }\end{array}$} & \multicolumn{2}{|c|}{+} & \multirow{2}{*}{\multicolumn{2}{|c|}{+++}} & +++ & \multicolumn{2}{|r|}{+} \\
\hline & & & & & - & \multicolumn{2}{|r|}{-} \\
\hline P1436 & \multirow{2}{*}{\multicolumn{2}{|c|}{ +++ }} & \multicolumn{2}{|c|}{ +++ } & + & \multicolumn{2}{|r|}{+++} \\
\hline P1438 & & & \multicolumn{2}{|c|}{+} & + & \multicolumn{2}{|r|}{+} \\
\hline AML 'MNC' & \multicolumn{2}{|c|}{ Kit-D } & \multicolumn{2}{|c|}{ 'Pici1' } & 'Pici2' & \multicolumn{2}{|r|}{ control } \\
\hline P1424 & \multirow{2}{*}{\multicolumn{2}{|c|}{-}} & \multirow{2}{*}{\multicolumn{2}{|c|}{+}} & - & \multicolumn{2}{|r|}{+++} \\
\hline P1426 & & & & & - & & + \\
\hline B $\quad 6 \mathrm{~B}^{\prime} 11^{+} / 6 \mathrm{~B} 11^{+}$ & $/ 6 \mathrm{~B}^{+} 1^{+}$ & $161^{+}$-il & T-cells a & er MLC & B-DC' an & MLC $^{* \prime W}$ & \\
\hline Healthy 'WB' & Kit-D & Kit-I & Kit-K & Kit-M & 'Pici1' & 'Pici2' & control \\
\hline P1420 & +++ & + & + & ++ & + & + & ++ \\
\hline P1428 & + & + & +++ & ++ & + & ++ & ++ \\
\hline P1429 & ++ & + & + & + & ++ & + & +++ \\
\hline P1436 & & & & + & +++ & + & + \\
\hline P1438 & - & - & - & +++ & ++ & - & + \\
\hline AML 'WB' & Kit-D & Kit-I & Kit-K & Kit-M & 'Pici1' & 'Pici2' & control \\
\hline P1424 & +++ & - & - & - & - & - & - \\
\hline P1426 & ++ & & + & + & + & + & +++ \\
\hline P1430 & + & + & +++ & & & & ++ \\
\hline P1433 & & - & & & & & - \\
\hline P1434 & & +++ & +++ & ++ & & & + \\
\hline P1439 & & & & +++ & & & ++ \\
\hline
\end{tabular}

8.2. iNKT-cells after MLC correlate with DC-values from healthy MNC

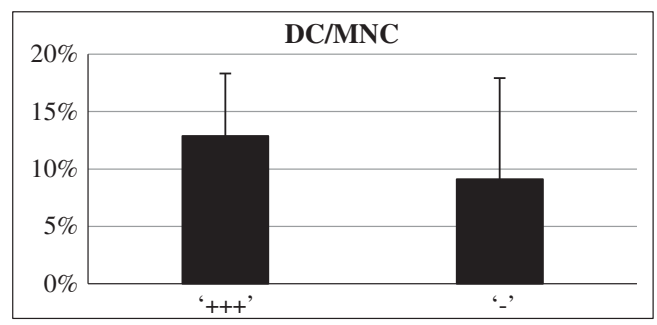

FIGURE 8. Frequencies of iNKT cells $\left(6 \mathrm{~B} 11^{+}\right.$or $6 \mathrm{~B} 11^{+} \mathrm{CD} 3^{+}$or $6 \mathrm{~B} 11^{+} \mathrm{CD} 161^{+} \mathrm{iNKT}$ cells) after MLC (MNC and WB) are given. T cellenriched immune reactive cells were stimulated with a stimulator cell suspension without pretreatment of MNC/WB [MLC*"MNC/WB"1 (control)] (B) or with a stimulator cell suspension pretreated with "cocktails" (MLC*"MNC/WB-DC"2) (C). AML indicates acute myeloid leukemia; DC, dendritic cells; iNKT, invariant natural killer T; MLC, mixed lymphocyte cultures; MNC, mononuclear cells; WB, whole blood. MNC/WB: "+ + +" "highest" counts of iNKT cells; " + + " "high" counts of iNKT cells, "+ " "good" counts of iNKT cells, "-." "no" increase or decrease of iNKT cells.

\section{iNKT, NK, CIK Cells Contribute to Antileukemic Activity}

As shown above iNKT cell proportions increase after MLC*“WB-DC" or MLC*“MNC-DC". Here we studied, whether iNKT/NK/CIK cells could contribute to improve the overallantileukemic activity after MLC. In a first step, we quantified these cells and their subtypes in individual AML-WB samples (precultured with various "cocktails") after MLC (with added $T$ cells and IL-2). In the next step, we correlated frequencies of iNKT, NK, CIK cells with the antileukemic activity [blast-lysis evaluated with a cytotoxicity (fluorolysis) assay] of the individual WB samples from AML patients.
We found that cases with versus without an antileukemic activity ("lysis" vs. "nonlysis") were characterized by significantly*** increased frequencies of $6 \mathrm{~B} 11^{+}$iNKT cells in the total MLC $(7.25 \% \pm 4.21 \%$ vs. $2.60 \% \pm 0.96 \%, P<0.0022)$ and significantly** higher frequencies of $6 \mathrm{~B} 11^{+} \mathrm{CD} 161^{+} / 6 \mathrm{~B} 11^{+}$ $\mathrm{CD}^{+}{ }^{+} \mathrm{iNKT}$ cells in MLC $(3.67 \% \pm 3.55 \%$ vs. $1.06 \% \pm 0.29 \%$, $P<0.0083 ; \quad 5.10 \% \pm 2.57 \%$ vs. $2.12 \% \pm 1.04 \%, \quad P<0.0232$, Fig. 9A). However, the subtype-compositions of iNKT and CIK cell subsets were comparable in the 2 groups compared $\left(6 \mathrm{~B} 11^{+}\right.$ $\mathrm{CD} 161{ }^{+} / \mathrm{CD} 161{ }^{+}: \quad 52.63 \% \pm 24.14 \%$ vs. $51.34 \% \pm 9.10 \%$; $6 \mathrm{~B} 11^{+} \mathrm{CD}^{+} / \mathrm{CD}^{+}: 18.45 \% \pm 15.34 \%$ vs. $17.25 \% \pm 9.79 \%$ $\mathrm{CD}^{+}{ }^{+} \mathrm{CD}_{161}{ }^{+} / \mathrm{CD}^{+}: 15.08 \% \pm 14.03 \%$ vs. $14.88 \% \pm 5.34 \%$, 
Fig. 9B). Moreover, significantly* higher proportions of $\mathrm{CD} 3^{+}$ CD $161{ }^{+}$CIK cells in MLC $(3.26 \% \pm 2.35 \%$ vs. $1.85 \% \pm 0.48 \%$, $P<0.0509)$ and significantly*** increased frequencies of $\mathrm{CD}^{-}{ }^{-} \mathrm{CD} 161^{+} \mathrm{NK}$ cells in MLC were found in cases with versus without an antileukemic activity $(2.07 \% \pm 2.13 \%$ vs. $0.21 \% \pm 0.13 \%, P<0.0023$, Fig. 9C). However, significantly* higher proportions of proliferating $\mathrm{T}$ cells $\left(\mathrm{T}_{\text {prol: }} \mathrm{CD}^{+}\right.$ $\left.\mathrm{CD} 9^{+} / \mathrm{MLC}\right)$ and significantly** higher frequencies of central memory $\mathrm{T}$ cells $\left(\mathrm{T}_{\mathrm{cm}}: \mathrm{CD} 3{ }^{+} \mathrm{CD} 45 \mathrm{RO}^{+} \mathrm{CCR}^{+}{ }^{+} \mathrm{MLC}\right)$ were found in cases with versus without an antileukemic activity $\left(\mathrm{T}_{\text {prol }}: 17.56 \% \pm 7.86\right.$ vs. $15.29 \% \pm 2.61 \%, P<0.0825, \mathrm{~T}_{\mathrm{cm}}$ : $9.35 \% \pm 10.47 \%$ vs. $2.32 \% \pm 1.5 \%, P<0.01451$, Fig. 9D). No significant differences were found in the composition of naive/non-naive $\mathrm{T}$ cells in the groups compared (dns).

Moreover, we assorted our samples according to their antileukemic activity ("lysis" vs. "nonlysis") and evaluated predictive cutoff values for $\mathrm{NK} / \mathrm{CIK} / \mathrm{iNKT}$ cells after MLC*"WB-DC" and MLC*"WB". A total of $100 \%$ of samples with $>4 \% 6 \mathrm{~B} 11^{+}$iNKT cells, with $>4 \% 6 \mathrm{~B} 11^{+} \mathrm{CD} 3{ }^{+}$ iNKT cells and with $>1.5 \% 6 \mathrm{~B} 11{ }^{+} \mathrm{CD} 161{ }^{+}$iNKT cells after MLC*"WB-DC" and MLC*"WB" showed antileukemic activity (lysis). Furthermore, $100 \%$ of samples with $>2.3 \%$ $\mathrm{CD} 3{ }^{+} \mathrm{CD} 161{ }^{+} \mathrm{CIK}$ cells and with $>1.9 \% \mathrm{CD} 3{ }^{+} \mathrm{CD}^{+}{ }^{+}$ CIK cells after MLC*"WB-DC" and MLC*"WB" showed antileukemic activity. Moreover, $89 \%-100 \%$ of samples with $>0.4 \% \mathrm{CD}^{-}{ }^{-} \mathrm{CD} 161^{+} \mathrm{NK}$ cells and with $>1.3 \%$ $\mathrm{CD}^{-}{ }^{-} \mathrm{CD}_{56}{ }^{+} \mathrm{NK}$ cells after MLC*“WB-DC" and MLC*"WB" showed antileukemic activity.

Further, we analyzed whether the addition of "cocktails" to cultures improves the antileukemic activity after MLC compared with controls. Samples with more lysis compared with controls, were defined as improved blast-lysis, samples with less lysis compared with controls as "not improved" blast-lysis. Samples with improved blast-lysis showed significantly* higher $6 \mathrm{~B} 11^{+}$iNKT cell frequencies compared with samples with not improved

\section{A iNKT-cells}
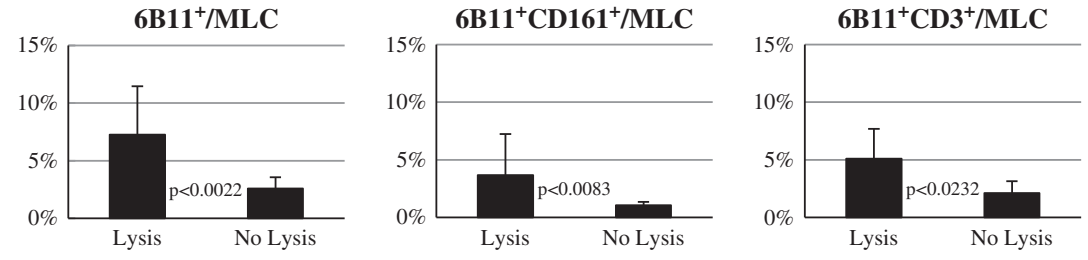

\section{$B$ iNKT- and CIK-cell subsets}

$6 \mathrm{~B}^{+} 1^{+} \mathrm{CD} 161^{+} / \mathrm{CD} 161^{+}$

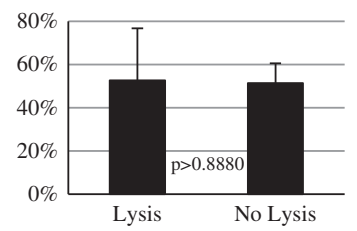

$6 \mathrm{B11}^{+} \mathrm{CD3}^{+} / \mathrm{CD3}^{+}$

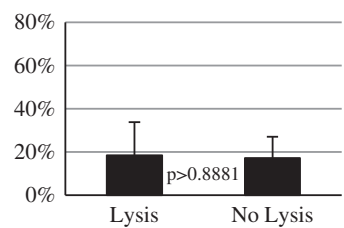

\section{$\mathrm{CD3}^{+} \mathrm{CD161}^{+} / \mathrm{CD3}^{+}$}

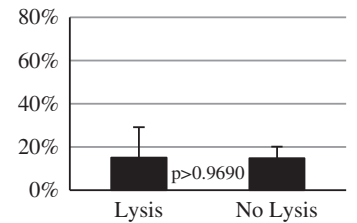

C CIK- and NK-cells

$\mathrm{CD3}^{+} \mathrm{CD}^{16}{ }^{+} / \mathrm{MLC}$

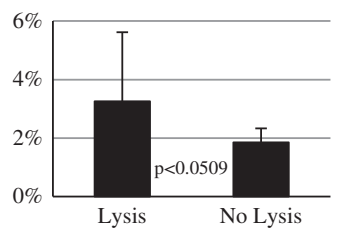

$\mathrm{CD3}^{-} \mathrm{CD}^{-161} / \mathrm{MLC}$

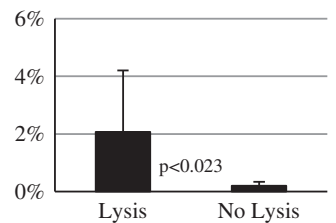

D T-cell subsets

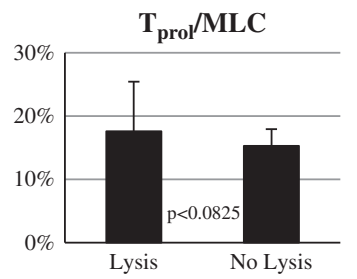

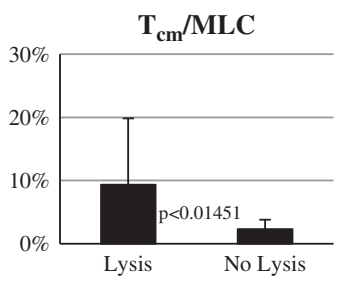

FIGURE 9. Frequencies of iNKT cells (A), CIK cells (B), NK cells (C), and T cell subsets (D) after MLC (MNC/WB) are given. T cellenriched immune reactive cells were stimulated with a stimulator cell suspension without pretreatment of MNC/WB [MLC*"MNC/WB" 1 (control)] or with a stimulator cell suspension pretreated with "cocktails" (MLC*"MNC/WB-DC"2) were compared in cases with/without blast lysis. Results were obtained with a cytotoxicity (fluorolysis) assay. CIK indicates cytokine-induced killer; iNKT, invariant natural killer $\mathrm{T}$; MLC, mixed lymphocyte cultures; NK, natural killer; Tprol, proliferating T cells $\left(\mathrm{CD} 69^{+} \mathrm{CD} 3^{+}\right)$, $\mathrm{Tcm}$, central-memory $\mathrm{T}$ cells $\left(\mathrm{CD} 45 \mathrm{RO}^{+} \mathrm{CCR} 7^{+}\right)$. 
blast-lysis $(7.94 \% \pm 4.12 \%$ vs. $4.39 \% \pm 3.12 \%, P<0.0921)$. Moreover, samples with improved blast-lysis showed (ns) higher frequencies of $6 \mathrm{~B} 11^{+} \mathrm{CD} 161^{+}$and $6 \mathrm{~B} 11^{+} \mathrm{CD} 3{ }^{+}$ iNKT cells compared with samples with not improved blastlysis $(4.82 \% \pm 3.49 \%$ vs. $1.80 \% \pm 2.90 \% ; 5.25 \% \pm 2.13 \%$ vs. $3.50 \% \pm 1.84 \%$ ). Furthermore, samples with "improved" blast-lysis showed (ns) higher frequencies of CD3 ${ }^{+} \mathrm{CD} 161^{+}$ CIK cells and $\mathrm{CD}^{-}{ }^{-} \mathrm{CD} 161^{+} \mathrm{NK}$ cells compared with samples with not improved blast-lysis $(3.99 \% \pm 2.51 \%$ vs. $2.10 \% \pm 1.83 \% ; 2.73 \% \pm 1.95 \%$ vs. $0.95 \% \pm 1.87 \%$ ).

Furthermore, we correlated findings of ELISA of supernatants of MLC*"WB-DC" and MLC*"WB" of samples from AML patients $(n=4)$ with antileukemic activity ("lysis" vs. "no lysis"). We could show that cases with achieved "lysis" compared with "no lysis" after MLC*"WBDC"/MLC*"WB" were characterized by higher release of antitumor and anti-inflammatory cytokines (IL-17A and IL-10), what correlated with higher iNKT, NK, and CIK cell frequencies.

With one exemplary experiment, we could show that a radiation of stimulator-cells did not reduce proportions of $\mathrm{T} / \mathrm{iNKT}$ /NK and CIK cells; however, reduced the overall blast-lysis compared with unirradiated settings. This could point to a role of $\mathrm{iNKT} / \mathrm{NK}$ and CIK cells beside $\mathrm{T}$ cells in antileukemic reactions (dns).

In summary in cases with antileukemic blast-lytic activity after MLC not only a $\mathrm{T}$ cell stimulation was induced, followed by a creation of memory $\mathrm{T}$ cells, but also that iNKT, NK, CIK cell proportions are significantly increased-pointing to an involvement of these cells in antileukemic reactions. Moreover, the presence of increased proportions (above cutoff values) of iNKT as well as of CIK and NK cells after MLC might correlate with successful blast-lysis.

\section{DISCUSSION}

\section{Role of T, iNKT, NK, and CIK Cells in Tumor- immune Surveillance}

$\mathrm{T}$, iNKT, NK, and CIK cells and their subsets are important mediators of immune responses: $\mathrm{T}$ cells are known to be activated by tumor or leukemia antigen-presenting DC and-as shown exemplarily by our $\mathrm{DC} / \mathrm{DC}_{\text {leu }}$ ex vivo strategies - their antitumor functionality can be improved by $\mathrm{DC}_{\text {leu }}{ }^{9} \mathrm{~T}_{\text {eff-em }}$ enable - in case of a secondary challenge - a very quick and immediate secondary immune response, while $\mathrm{T}_{\text {reg }}$ are able to downregulate immune responsesimportant to inhibit autoaggressive immune reactions-but also in a context to downregulate antitumor responses. ${ }^{9,10}$ In contrast to $\mathrm{T}$ cells, iNKT, NK, and CIK cells react quickly to an immunologic threat by secreting cytokines and chemokines ${ }^{4,30}$ and kill tumor cells without prior activation and, unlike $\mathrm{T}$ and iNKT cells, NK and CIK cells do not recognize target cells by a TCR. ${ }^{5}$ iNKT cells can produce a variety of chemokines and cytokines like IFN- $\gamma$, IL-4/IL-2/IL-12, tumor necrosis factor (TNF)- $\alpha$, transforming growth factor$\beta$, and GM-CSF that in consequence activate different cells like DC, NK cells, CD4 ${ }^{+} / \mathrm{CD} 8{ }^{+} \mathrm{T}$ cells, but also $\mathrm{T}_{\text {reg. }}{ }^{31,32}$ A previous study could show that all subsets of iNKT cells produce almost the same amounts of IFN- $\gamma$ and TNF- $\alpha$, while IL-4 is mainly produced by PB-CD4 ${ }^{+}$iNKT cells. $^{13}$ Moreover, iNKT cells show a strong cytolytic potential and can directly kill tumor cells as they express granzyme-B, Perforin, and FasL. ${ }^{4,31}$ Therefore, it might be promising to use or even to increase the antileukemic potential of NK, CIK cells and especially iNKT cells to enhance the patients' anti-tumor immune response.

\section{Methods to Detect iNKT, NK, and CIK Cells}

The identification and quantification of iNKT cells (in healthy blood samples) is known to be difficult due to their low frequency as well as missing marker (combinations). Previous methods using CD1d tetramers or the combination of V $\alpha 24-/ V \beta 11$-antibodies did not yield the necessary specific results. ${ }^{13}$ Therefore, the first aim of our study was to develop a highly specific iNKT cell detection panel for the quantification of iNKT cells/subsets in healthy, but also to be used for leukemia patients. Furthermore, we compared strategies and markers to detect and quantify NK and CIK cells and their subsets in healthy, but especially in leukemic patients. A previous study performed with healthy samples could show that a new moAb (clone 6B11-PE) can recognize the invariant CDR3 loop of the $\mathrm{V} \alpha 24 \mathrm{~J} \alpha 18$-TCR rearrangement on the cell surface and can be used to specifically characterize iNKT cells in combination with anti-CD3. ${ }^{13}$ In our current study, we also used 6B11-PE, but also 6B11-FITC (purchased from different companies) to characterize and define iNKT cells. In previous studies, ${ }^{11,13}$ only $6 \mathrm{~B} 11-\mathrm{PE}$ was used for analysis, but not 6B11-FITC. We found (significantly) higher proportions of iNKT cells detected with 6B11-FITC compared with 6B11-PE in AML, ALL, CLL patients. The proportions of iNKT cells detected with 6B11-FITC compared with 6B11-PE were (significantly) lower in healthy samples. Moreover, 6B11-FITC-stainings seemed to yield varying results in several stainings, whereas 6B11-PEstainings showed stable and precise results for iNKT detection. It is well known, that moAbs can react and bind differently to their targets - depending not only on the selected clones, but also on the purchasing companies, the fluorochromes used or the combination with partner moAbs in a panel. ${ }^{33}$ In order to exclude these variations, we focused mainly on 6B11-PE results in our setting.

Coexpression analyses of 6B11 with myeloid (eg, CD33, CD34, CD117) or lymphoid (eg, CD1a, CD5, CD7, CD10, CD19, CD20) markers on blasts from malignant myeloid and lymphoid cell lines showed, that 6B11 was not expressed on myeloid or B-lymphoid blasts. However, we found a low expression of $6 \mathrm{~B} 11$ on T-linear cells of the Jurkat cell line. As we do not know, whether this cell line has a V $\alpha 24-/ V \beta 11-$ rearrangement, typical for iNKT cells we cannot decide whether this expression is "aberrant" on this cell line or specific. In general, our results show, that the 6B11-PE-marker, but not 6B11-FITC, can be regarded as a very specific marker to detect iNKT cells without cross-reactivity or aberrant expression on leukemic cells. Previous studies did not analyze whether $6 \mathrm{~B} 11$ is aberrantly expressed on leukemic blasts and if 6B11-FITC is specific for iNKT cells analyses. Thereby, we can confirm preliminary findings of other groups, that the detection of iNKT cells with 6B11 alone or in combination with subtype markers is very precise, as 6B11 specifically recognizes the CDR3 loop of the invariant TCR of CD1drestricted iNKT cells. ${ }^{13}$

It is known, that the iNKT cell population consists of different subsets with diverse phenotypic and functional characteristics that can be subdivided according to their expression of surface molecules, receptors, effector functionality or tissue localization. ${ }^{4}$ In a former study it was shown that $6 \mathrm{~B} 11$ could be used in combination with further 
T (CD27, CD28, CD45RA, CD45RO) and NK cell markers (CD16, CD56, CD161) to analyze iNKT subsets. ${ }^{13}$ Moreover, iNKT cells were characterized by the combination of CD1d and CD3 or the combination of $\mathrm{V} \alpha 24$ and $\mathrm{V} \beta 11$. The percentage of iNKT cells expressing CD4 or $\mathrm{CD} 8$ was evaluated in a region comprising $6 \mathrm{~B} 11^{+} \mathrm{CD} 3{ }^{+}$ iNKT cells. Like the previous study, we used $6 \mathrm{~B} 11$ in combination with CD3, CD45R0, and CD161. Moreover we included the combinations of $6 \mathrm{~B} 11$ with $\mathrm{CD} 1 \mathrm{~d}, \mathrm{~V} \alpha 24$, CD4 or with CD8. This means that we evaluated the expression of T cell (CD1d, CD3, CD45RO, V $\alpha 24)$ and NK cell markers (CD161) on $6 \mathrm{~B} 11^{+}$iNKT cells and divided them into "T cell-like" and "NK cell-like" iNKT subsets. We are the first group, that defined "T cell-like" iNKT subsets as $\mathrm{CD} 3{ }^{+} 6 \mathrm{~B} 11^{+}, \mathrm{CD} 4{ }^{+} 6 \mathrm{~B} 11^{+}, \mathrm{CD} 8^{+} 6 \mathrm{~B} 11^{+}$, $\mathrm{V} \alpha 24^{+} 6 \mathrm{~B} 11^{+}, \mathrm{CD}_{1 \mathrm{~d}}{ }^{+} 6 \mathrm{~B} 11^{+}, \mathrm{CD} 45 \mathrm{RO}{ }^{+} 6 \mathrm{~B} 11^{+}$, and $\mathrm{CD}^{2} 5 \mathrm{RO}^{-} 6 \mathrm{~B} 11^{+} \mathrm{iNKT}$ cells.

Classically, iNKT cells have been identified with CD1d-tetramers loaded with $\alpha$-galactosylceramide, but this method could lead to an overestimation of iNKT cells as some $\mathrm{T}$ cell subsets also express CD1d. ${ }^{13}$ This study did not find significant differences in $6 \mathrm{~B} 11^{+}$iNKT cells compared with $\mathrm{CD} 3{ }^{+} 6 \mathrm{~B} 11^{+}$iNKT cells or $\mathrm{CD} 3{ }^{+} \mathrm{CD} 1 \mathrm{~d}^{+}$iNKT cells in healthy samples. Although we did not combine CD1d with CD3, but with $6 \mathrm{~B} 11$, we could also show that frequencies of $6 \mathrm{~B} 11^{+} \mathrm{CD} 3{ }^{+}$and $6 \mathrm{~B} 11^{+} \mathrm{CD} 1 \mathrm{~d}^{+}$iNKT cells were comparable in healthy samples. We could show in addition that frequencies of $6 \mathrm{~B} 11^{+} \mathrm{CD}^{+}$and $6 \mathrm{~B} 11^{+}$ $\mathrm{CD}^{+}{ }^{+}$iNKT cells were similar in AML, ALL, and CLL samples. Unlike the previous study, ${ }^{13}$ we detected higher numbers of $6 \mathrm{~B} 11^{+}$iNKT cells compared with $6 \mathrm{~B} 11^{+}$ $\mathrm{CD}^{+}$and $6 \mathrm{~B} 11^{+} \mathrm{CD} 1 \mathrm{~d}^{+}$iNKT cells in healthy samples as well as in AML, ALL, and CLL samples.

Using CD3-/V $\alpha 24$-antibodies, we could demonstrate specific results and detected lower frequencies of $\mathrm{V} \alpha 24^{+} 6$ $\mathrm{B} 11^{+}$iNKT cells compared with $\mathrm{CD} 3{ }^{+} 6 \mathrm{~B} 11^{+}$iNKT subsets in healthy as well as in AML, ALL, and CLL patients. These findings are consistent with a previous study, which found 3 times more $\mathrm{CD}^{+} 6 \mathrm{~B} 11^{+}$iNKT cells compared with $\mathrm{CD}^{+} \mathrm{V} \alpha 24^{+} \mathrm{V} \beta 11^{+}$iNKT cells in healthy adult and children's samples. ${ }^{11}$ However, this group combined $\mathrm{V} \alpha 24$ with CD3 and V $\beta 11$, while we combined $\mathrm{V} \alpha 24$ with $6 \mathrm{~B} 11$. Unlike these results, another group found similar proportions of $\mathrm{CD}^{+} 6 \mathrm{~B} 11^{+}$iNKT cells and $\mathrm{V} \alpha 24^{+} \mathrm{V} \beta 11^{+}$iNKT cells in healthy controls. ${ }^{13}$ However, this group used the combination of $\mathrm{V} \alpha 24$ and $\mathrm{V} \beta 11$ without combining it with CD3. These differences may be explained by the fact, that different combinations of V $\alpha 24$ with CD3, V $\beta 11$ or $6 \mathrm{~B} 11$ were used for iNKT cell detection. Furthermore, the results or our group and Bienemann may be explained by the fact that the invariant $\alpha$-chain of the TCR sometimes binds with other $\beta$-chains than V $\beta 11$, which could lead to an underestimation of iNKT cells. ${ }^{11}$

Both type I iNKT cells and type II iNKT cells, are divided into $\mathrm{CD}^{+}, \mathrm{CD}^{-}{ }^{-} \mathrm{CD} 8^{-}, \mathrm{CD} 8 \alpha \alpha^{+}$, and $\mathrm{CD} 8 \alpha \beta^{+}$iNKT cells, with higher proportions being $\mathrm{CD} 4^{+}$, lower proportions being $\mathrm{CD} 4^{-} \mathrm{CD} 8^{-}$and only a few cells CD $8 \alpha \alpha^{+}$or $\mathrm{CD} 8 \alpha \beta^{+}$, which could only be found in humans but not in mice. ${ }^{4}$ Unlike previous studies, we combined 6B11 with CD4 and CD8 for subtype analyses. We can confirm that the majority of $6 \mathrm{~B} 11^{+}$iNKT cells coexpresses $\mathrm{CD}^{+}{ }^{+}$and the minority $\mathrm{CD} 8{ }^{+}$in healthy samples. We can add as a new finding in addition, that higher proportions of $6 \mathrm{~B} 11^{+} \mathrm{CD} 4{ }^{+} \mathrm{iNKT}$ cells and lower proportions of $6 \mathrm{~B} 11^{+} \mathrm{CD} 8{ }^{+} \mathrm{iNKT}$ cells were also found in AML, ALL and CLL patients. A previous study suggested that $\mathrm{CD}^{+}{ }^{+}$iNKT cells produce both Th1 and Th2 cytokines, whereas $\mathrm{CD}^{-}{ }^{-}$iNKT cells tend to produce mainly Th1 cytokines. ${ }^{31}$ However, another study found that $\mathrm{CD}^{+}{ }^{+}, \mathrm{CD}^{-}{ }^{-}$, and $\mathrm{CD} 8{ }^{+}$iNKT cells produced similar amounts of IFN- $\gamma$ and TNF- $\alpha$, but CD $4{ }^{+}$iNKT cells produced significantly more IL- $4 .{ }^{13}$ In our patients' cohort, we had not further analyzed the functional role of CD4 and CD8 expressions on iNKT cells. However, we suggest to combine 6B11 with CD4 and CD8 to analyze the diffences between $6 \mathrm{~B} 11^{+} \mathrm{CD} 4{ }^{+}, 6 \mathrm{~B} 11^{+} \mathrm{CD} 4{ }^{-}, 6 \mathrm{~B} 11^{+} \mathrm{CD} 8{ }^{+}$, and $6 \mathrm{~B} 11^{+} \mathrm{CD} 8-$ iNKT cells.

Consistent to a previous study we found that the majority of iNKT cells is $\mathrm{CD}^{2} 5 \mathrm{RO}^{+} 6 \mathrm{~B} 11^{+}$, while the minority is $\mathrm{CD}_{4} 5 \mathrm{RO}^{-} 6 \mathrm{~B} 11^{+}$, what could be interpreted as iNKT cells with a memory-effector phenotype. ${ }^{13}$

We defined "NK-like" iNKT cells as CD161 ${ }^{+} 6 \mathrm{~B} 11^{+}$ iNKT cells and found lower proportions of $\mathrm{CD}_{161}{ }^{+} 6$ $\mathrm{B} 11^{+}$iNKT cells compared with $6 \mathrm{~B} 11^{+}$iNKT cells and $6 \mathrm{~B} 11^{+} \mathrm{CD}^{+}$iNKT cells ("T-like" iNKT cells). A previous study showed different NK cell markers expressed by iNKT cells and demonstrated that the majority of iNKT cells expressed CD161, while only a minority expressed CD56 and CD16. Furthermore, this study showed that CD161 was expressed on significantly higher frequencies of $\mathrm{CD}^{+}{ }^{+}$or double negative iNKT cells compared with CD4 ${ }^{+}$iNKT cells. CD161 (KLRB1) is a C-type lectin receptor expressed on human NK cells, but also on iNKT and $\mathrm{T}$ cell subsets - especially on subgroups found in liver and gut. ${ }^{13-15,18}$ In humans, the CD161 receptor interacts with its ligand LLT1 and suppresses the cytotoxic potential of NK cells. Moreover, it was shown that an infection with cytomegalovirus leads to decreased expression of CD161 on NK cells. ${ }^{34}$

In conclusion, we suggest that the most precise detection of iNKT cells should be based on 6B11-PE alone or in combination with CD3 and CD161-moAbs. Moreover, we found new detection methods for iNKT cells/ subsets using 6B11 in combination with CD1d, Va24, CD4 or CD8. Furthermore, we could demonstrate that $6 \mathrm{~B} 11$ can be used to analyze iNKT cells of leukemia patients, knowing that there is no aberrant expression of $6 \mathrm{~B} 11$ on blasts. Our results confirm the heterogeneity of iNKT cells, as we could show that there are various "T cell-like" and "NK cell-like" iNKT subsets. This highlights that the iNKT cell population consists of several phenotypically and potentially functionally different subsets with diverse surface markers. A previous study could demonstrate that neonatal $\mathrm{CD}^{+}{ }^{+}$, adult $\mathrm{CD} 4^{+}$, and adult $\mathrm{CD} 4^{-}$iNKT cells are phenotypically diverse and show different effector/ memory T-cell markers and NK cell markers. Neonatal CD4 ${ }^{+}$iNKT cells show a more naive phenotype and can be modified more easily in their capacity to acquire Th1-like or Th2-like functions compared with adult iNKT cells, which are mainly resistant to functional reprogramming, but show higher cytotoxic functions. ${ }^{35}$

To detect NK and CIK cells, we used recommended combinations of CD3 with CD161 or CD56 moAbs. NK cells were defined as $\mathrm{CD} 3{ }^{-} \mathrm{CD} 56^{+}$or $\mathrm{CD} 3{ }^{-} \mathrm{CD} 161^{+}$cells and CIK cells were defined as $\mathrm{CD} 3^{+} \mathrm{CD} 56^{+}$or $\mathrm{CD} 3^{+}$ $\mathrm{CD} 161^{+}$cells. Both combinations detect similar amounts of NK and CIK cells in healthy controls. However, CD56 is known to be aberrantly expressed on blasts of certain AML-subtypes and correlates with a worse prognosis. ${ }^{36}$ In these cases, NK cells cannot be evaluated with a CD56- 
marker. We recommend using the CD161-moAb to quantify NK cells in cases with aberrant expression of CD56. Therefore, CD161 can be regarded as a better NK and CIK cell marker for leukemic patients with aberrant CD56 expression.

In conclusion, we suggest that NK and CIK cells can always be detected with the combination of CD3 with CD161-moAbs and with CD3 and CD56-moAbs in cases without aberrant expression of CD56. The potential functional differences in these subsets, however, should be evaluated.

\section{iNKT, NK, and CIK Cells in AML, ALL, and CLL Patients Compared With Healthy Samples}

The present study shows that AML, ALL as well as CLL patients' $\mathrm{MNC}$ are characterized by (significantly) lower frequencies of $\mathrm{CIK}$ cells $\left(\mathrm{CD} 3{ }^{+} \mathrm{CD}_{5} 6^{+}\right.$or $\left.\mathrm{CD} 161^{+}\right)$, NK cells $\left(\mathrm{CD} 3^{-} \mathrm{CD} 56^{+}\right.$or $\left.\mathrm{CD} 161^{+}\right)$and iNKT cells $\left(6 \mathrm{~B} 11^{+}, 6 \mathrm{~B} 11^{+} \mathrm{CD} 3^{+}\right.$or $\mathrm{CD} 8{ }^{+}$or $\mathrm{CD} 161^{+}$ or $\mathrm{V} \alpha 24^{+}$) compared with healthy donors. This could be confirmed by another group that demonstrated significantly lower median values of NK cells, NKT, and iNKT cells in AML patients compared with healthy donors' PB (cells $/ \mu \mathrm{L}$ : 303.47 vs. $101.54 ; 55.86$ vs. $21.85 ; 0.515$ vs. 0.0814$){ }^{7}$ However, this group did not compare values of CIK cells in AML patients versus healthy and did not consider different NK and iNKT subsets: NK and NKT cells were detected with CD3 and CD16/56 and iNKT cells with CD3 in combination with $\mathrm{V} \alpha 24$ and $\mathrm{V} \beta 11 .^{7}$ In general, these findings can be expected due to the displacement of immunereactive cells by uncontrolled proliferating and expanding blasts.

In summary, we could show that a high blast-load in AML, ALL or CLL patients directly correlated with low frequencies of iNKT, NK, and CIK cells. Therefore, the majority of iNKT, NK, and CIK cells is displaced by blasts in AML, ALL, and CLL patients.

An interesting finding was, that-although proportions of iNKT, NK, and CIK cells were comparable in leukemic patients, their subtype composition was different in leukemic patients compared with healthy donors showing a shift to (significantly) higher frequencies of $\mathrm{T}$ and $\mathrm{NK}$ cells coexpressing 6B11 in AML, ALL, and CLL patients compared with healthy donors. This might suggest that certain $\mathrm{T} / \mathrm{NK}$-derived iNKT cells in leukemic patients might either be subtypes with downregulated antileukemic functionality or could be special subsets that could be triggered in antileukemic reactivity.

In summary, we present the new finding that proportions of iNKT, NK, and CIK cells were significantly lower in AML, ALL, and CLL patients and compared with healthy donors. Their subset compositions as well as iNKT subsets were comparable in AML, ALL, and CLL patients. We can demonstrate in addition to findings in the literature a shift to higher proportions of T and NK cells expressing 6B11 in AML, ALL, and CLL patients compared with healthy donors, what might point to comparable mechanisms in leukemic diseases, that favor the extension of subsets in these diseases and what might help to develop new iNKT, NK, and CIK cell-based immune therapeutic strategies for leukemia patients.

\section{Prognostic Relevance of iNKT, NK, and CIK Cells in AML, ALL, and CLL Patients}

A previous study could show, that the overall number of iNKT cells in AML patients is an important prognostic factor as iNKT cell proportions $>0.2$ cells $/ \mu \mathrm{L}$ are associated with favorable survival. ${ }^{7}$ Furthermore, this study could demonstrate, that a lower number of iNKT cells in $\mathrm{PB}$ in combination with higher proportions of $\mathrm{CD}^{+}$and $\mathrm{CD} 8{ }^{+} \mathrm{T}$ cells in $\mathrm{BM}$ at diagnosis is characterized by a lower overall survival (OS) in AML patients. Another study could demonstrate that a high expression of NKp30/ NKp46 on $\mathrm{CD} 16^{+} \mathrm{NK}$ cells in elderly AML patients correlated with leukemia-free and better OS. ${ }^{37}$ Moreover, previous studies pointed out that CIK cells (especially $\mathrm{CD} 3{ }^{+} \mathrm{CD} 6^{+}$) show strong cytotoxic potential, for example against leukemia, ${ }^{4,30}$ but did not correlate the frequencies of CIK cells with survival or favorable prognosis for leukemia patients. With our results we confirm these findings and can add in addition, that higher percentages of iNKT, NK, and CIK cells correlate with the allocation of patients to diverse prognostically more favorable subgroups not only in AML, but also in ALL and CLL.

We could show, that higher frequencies of iNKT cells in leukemic patients correlate with prognostically better subsets in AML, adult ALL, and CLL patients. AML patients with favorable (vs. adverse) NCCN risk score showed higher percentages of $6 \mathrm{~B} 11^{+}, 6 \mathrm{~B} 11^{+} \mathrm{CD} 161^{+}$, and $6 \mathrm{~B} 11^{+} \mathrm{Va} 24^{+}$iNKT cells. Moreover, AML and CLL patients younger (vs. older) than 60 years showed higher numbers of $6 \mathrm{~B} 11^{+}, 6 \mathrm{~B} 11^{+} \mathrm{CD} 161{ }^{+}, 6 \mathrm{~B} 11^{+} \mathrm{CD} 3{ }^{+}$, and $6 \mathrm{~B} 11^{+} \mathrm{Va} 24^{+}$iNKT cells. AML patients with primary (vs. secondary) AML showed higher frequencies of $6 \mathrm{~B} 11^{+}$ and $6 \mathrm{~B} 11^{+} \mathrm{CD} 3{ }^{+}$iNKT cells. Furthermore, AML and adult ALL patients without (vs. with) extramedullary foci showed higher frequencies of $6 \mathrm{~B} 11^{+}, 6 \mathrm{~B} 11^{+} \mathrm{CD} 3^{+}$, $6 \mathrm{~B} 11^{+} \mathrm{CD}_{161}{ }^{+}$, and $6 \mathrm{~B} 11^{+} \mathrm{Va} 24^{+}$iNKT cells. Moreover, adult ALL patients achieving CR after GMALL induction chemotherapy (vs. NCR) and CLL patients with no need (vs. need) for therapy showed higher frequencies of $6 \mathrm{~B} 11^{+}, 6 \mathrm{~B} 11^{+} \mathrm{CD} 3^{+}$, and $6 \mathrm{~B} 11^{+} \mathrm{Va} 24^{+}$iNKT cells. AML and CLL patients with stable CR (vs. no stable CR: relapse or death by disease) showed (significantly) higher percentages of $6 \mathrm{~B} 11^{+}, 6 \mathrm{~B} 11^{+} \mathrm{CD} 3^{+}$, and $6 \mathrm{~B} 11^{+}$ CD161 ${ }^{+}$iNKT cells, however, 1 patient had died from pneumonia. This data can confirm previous findings $7,37,38$ that low frequencies of iNKT cells can be correlated with worse prognosis and worse OS. In contrast to previous studies and our results, another study found that lower frequencies of NK and NK like T cells correlated with higher survival in AML patients, while higher frequencies were correlated with poor survival. $7,37,38$

Moreover, we could show, that higher frequencies of NK cells in leukemia patients correlate with prognostically better subsets in AML, adult ALL, and CLL patients. AML patients without (vs. with) extramedullary foci showed (significantly) higher frequencies of CD3 ${ }^{-} \mathrm{CD} 56^{+}$ NK cells. Moreover, adult ALL patients, who had achieved CR after GMALL induction chemotherapy, showed higher numbers of $\mathrm{CD} 3{ }^{+} \mathrm{CD} 161^{+} \mathrm{NK}$ cells. Furthermore, AML and CLL patients, who stayed in stable CR (vs. no stable $\mathrm{CR}$ ) showed higher amounts of $\mathrm{CD}^{-} \mathrm{CD} 161^{+}$and $\mathrm{CD} 3{ }^{+} \mathrm{CD} 56{ }^{+} \mathrm{NK}$ cells. Consistent to previous studies, ${ }^{7,37,38}$ our data show that higher percentages of NK cells 
can be correlated with better prognosis and stabilization of disease. In contrast to a previous study, we could not correlate low frequencies of NK cells with better survival. $7,37,38$

We can add in addition, that higher frequencies of CIK cells in leukemia patients correlate with prognostically better subgroups in AML and CLL patients. AML patients who achieved CR (vs. NCR) and CLL patients with no need for initial therapy (vs. need for initial therapy) showed (significantly) more CIK cells. Moreover, AML as well as ALL patients without extramedullary foci presented with significantly more CIK cells. Furthermore, AML and CLL patients, who stayed in stable CR (vs. no stable CR), showed higher numbers of $\mathrm{CD} 3{ }^{+} \mathrm{CD}_{161}{ }^{+}$and $\mathrm{CD} 3{ }^{+}$ $\mathrm{CD}^{+} 6^{+}$CIK cells. Consistent to previous studies, ${ }^{4,30}$ these data might point to an antileukemic reactivity of CIK cells - leading to stabilized disease.

We conclude that higher frequencies of iNKT, NK as well as CIK cells can be regarded as a favorable prognostic factor for AML, adult ALL, and CLL patients. For the future, we recommend to perform subtype-analyses of iNKT, NK as well as CIK cells in more detail to be able to allocate defined subtypes to prognostic groups. Moreover, we recommend multifactorial statistical analyses to work out the role of cellular partners involved in the mediation of anti-leukemic reactions and better prognosis for individual pts in more detail.

\section{iNKT, NK, CIK Cells Contribute to Antitumor and Antileukemic Activity}

A previous study has shown, that iNKT cells are important mediators in tumor-protection, as reduced frequencies of iNKT cells were correlated with a variety of cancers and increased frequencies of iNKT cells were related with favorable response to therapy. ${ }^{39}$ Another study showed, that NK and CIK cells have cytotoxic potential against leukemia and other cancers. ${ }^{30,40-42}$

In the current study, we could show in general, that higher proportions of iNKT, NK, and CIK cells and higher frequencies of proliferating $T$ cells and $T_{c m}$ correlated with antileukemic activity (blast-lysis). Moreover, we could show (although only with one exemplary experiment up to now), that radiation of stimulator-cells did not reduce proportions of $\mathrm{T} / \mathrm{iNKT} / \mathrm{CIK}$ and $\mathrm{NK}$ cells, but reduce the overall blast lysis of (stimulator cell activated) effector cellmediated antileukemic activity compared with unradiated settings - what could be explained by a functional knockout of these T/iNKT/CIK and NK cells and therefore point to their antileukemic contribution. Consistent, a previous study has shown that in knockout experiments in mice absence of iNKT cells was correlated with tumor-growth and poor survival, while a transfer of iNKT cells into mice could reduce tumor growth. ${ }^{39}$ All of these results emphasize the relevance of iNKT/CIK and NK cells in antileukemic reactions. More studies have to be performed to work out the specific role of these cell fractions in the mediation of antileukemic reactions. To further analyze the function of different iNKT/CIK or NK cells and their subtypes we recommend performing, for example blocking experiments knocking out certain cellular subtypes and correlating results with antileukemic function.

With an attempt to evaluate the predictivity of iNKT/ CIK and NK cell frequencies we defined cutoff values: we could show that cases presenting with higher values of iNKT (subtypes) or CIK or NK cells were characterized by a higher chance to belong to the group with "antileukemic activity."

In summary, we suggest to define and applicate cut-off values for iNKT/CIK and NK cells and their subtypes for leukemia-pts in the future to enable a refined estimation of prognosis.

\section{Induction of iNKT, NK, and CIK Cells After Stimulation With $\mathrm{DC} / \mathrm{DC}_{\text {leu }}$}

It was already shown, that a crosstalk between NK cells and DC improves antitumor reactions. Recently, details about the mechanisms behind the increase of antitumor-reactivity (eg, pathogen-associated molecular patterns or cytokines) have been detected. ${ }^{39,43}$ Moreover cytokines, cellular factors, antibodies promote NK cell activations, and DC-NK crosstalk establishing a microenvironment which enables antitumor reactions. ${ }^{44,45}$ Moreover, a crosstalk between CIK cells and DC has been reported recently, demonstrating an influence of a DC stimulation on the phenotype as well as antileukemic cytotoxicity of CIK cells. ${ }^{46}$ Recently a crosstalk between DC and iNKT cells has been shown (mediated, eg, by chemokine receptor-expression), leading to an amplification of antitumor-immune reactions. ${ }^{4,47}$

With our data, we contribute that iNKT cells not only respond to a stimulus with IL-2, but in addition are significantly expanded in cases with previous treatment of AML-or healthy MNC/WB with "cocktails." Comparable phenomena were found for CIK cells. These finding might point to an induction of these cell-populations by $\mathrm{DC} /$ $\mathrm{DC}_{\text {leu }}$ stimulation.

Moreover, we can add important new data to a previous study that highlighted 3 possible mechanisms of antitumor-reactivity mediated by iNKT cells: indirect cytotoxicity, direct cytotoxicity and modulation of the tumor microenvironment. "Indirect cytotoxicity" means that iNKT cells and DC stimulate each other by TCR/ CD1d and CD40/CD154 interactions leading to a release of cytokines (e.g. IL-10, IL-17A, IFN- $\gamma$, and IL-12) and increased antitumor activity of other effector cells. ${ }^{39,43}$ Mature DCs are known to produce IL-12 stimulating iNKT cells to increase IFN- $\gamma$ release coactivating NK cells and their production of IFN- $\gamma,{ }^{39}$ what could in return lead to a release of pro-inflammatory cytokines by DC. ${ }^{43}$ Our preliminary data obtained with some cases in part confirm these findings: increased release of cytokines (IL-17A, IL10) correlated with achieved "lysis"/antitumor activity and with higher iNKT, NK and CIK cell frequencies - pointing to a cytokine-mediated antitumor activity. ${ }^{39}$ Moreover, we could show that "highest" iNKT cell frequencies were correlated with higher DC-pointing to a coactivation between iNKT cells and DC.

Recently it was shown, that soluble as well as cellular components of the immune-system are involved in a "crosstalk" with NK/iNKT cells leading to a "cross-priming" in infectious diseases or cancer: for example, IL-21 improved cytotoxicity and increased IFN $-\gamma$ production of NK cells against breast cancer cells, ${ }^{48}$ TH17 frequencies directly correlated with iNKT frequencies and good prognosis in CLL ${ }^{49}$ and iNKT cells were shown to be involved in cross-talk between $\mathrm{DC}$ and $\mathrm{CD} 8{ }^{+}$cells - at least in infectious diseases. ${ }^{50}$ These findings emphasize the importance to study these kinds of cross-talks in detail in future studies. 
We can add in addition that the highest $6 \mathrm{~B} 11^{+} \mathrm{iNKT}$ and CIK values were found after culture in prostaglandincontaining "cocktails." This could point to a special effect of these "cocktails" on the allocation and recruitment of iNKT and CIK cells - resulting in an improved antileukemic activity - up to now an effect of Prostaglandin $E_{2}$ on the maturation of DC has been shown. ${ }^{19,28}$ Alternatively, it might be discussed, that "only" the $6 \mathrm{~B} 11$ or CD56-antigens are upregulated on $\mathrm{T} / \mathrm{NK}$ cells, however without expansion of functionally reactive iNKT/CIK cell populations.

\section{Physiologic Culture-conditions (Hypoxia, WB) Do Not Have an Effect on the Generation of DC Nor on the Frequencies and Composition of iNKT, NK or CIK Cells}

Preliminary experiments with MNC/WB cultured under hypoxic versus normoxic conditions did not yield an effect on the generation of DC nor on the frequencies and composition of iNKT, NK, and CIK cells after MLC. Although more experiments have to be performed we can assume, that working under normoxic conditions yields "physiological" data.

\section{CONCLUSIONS}

In conclusion, we recommend to regularly evaluate proportions of iNKT/NK/CIK cells and include specific markers in diagnosis panels (based on 6B11/CD161/CD56/ CD3 antibodies) in AML/ALL/CLL for quantitative, qualitative, and prognostically relevant estimation of individual patients antileukemic potential. Detection of iNKT cells should be based on 6B11-(PE)-staining alone or in combination with (especially) CD3 and CD161; NK and CIK cell detection should be based on the combination of CD3 with CD161 or with CD56 (in cases without aberrant expression of CD56). As we could demonstrate a shift to higher proportions of $\mathrm{T}$ and NK cells expressing $6 \mathrm{~B} 11$ in AML, ALL, and CLL patients compared with healthy donors, we suggest that mechanisms behind these subtype extensions have to be studied in detail. These findings might be considered in the development of iNKT-based immunotherapies.

Considering that higher frequencies of iNKT, NK, and CIK cells correlate with prognostically better subgroups and with antileukemic activity (blast lysis) in AML, adult ALL, and CLL patients, high amounts of iNKT, NK, and CIK cells can be regarded as a favorable prognostic factor in leukemic patients.

Moreover, proportions of iNKT and CIK cells increase under stimulation of MLC with IL-2 and particularly after culture with (prostaglandin-containing) DC/ $\mathrm{DC}_{\text {leu }}$-inducing "cocktails". Cytokine profiling revealed a correlation of release of antitumor and anti-inflammatory cytokines with higher frequencies of iNKT, NK, and CIK cells after MLC, what correlated with improved antileukemic cytotoxicity. These findings not only point to a cross-talk between soluble factors and these immune reactive cells and DC, but in addition a correlation with an improved antileukemic reactivity. In conclusion, "cocktails" not only activate antileukemic T cells, but also iNKT and CIK cells and improve the antileukemic activity. Inclusion of prostaglandin-containing $\mathrm{DC} / \mathrm{DC}_{\mathrm{leu}}$-generating methods might be especially promising in the recruitment of antileukemic active immune reactive cells.

Although the quantification of these small cell populations (using selected markers and special gating- strategies in flow cytometric settings) has to be performed from experienced groups and the contribution of these cell populations to antileukemic reactions should not be underestimated.

Novel immunotherapeutic protocols in the treatment of pts with leukemia should be designed, that include the quantification of iNKT, NK, and CIK cells and their subtypes in diagnostic panels. Moreover, the role of iNKT, $\mathrm{NK}$, and CIK cells as well as soluble factors in a cross-talk in $\mathrm{DC} / \mathrm{DC}_{\text {leu}}$-triggered antileukemic reactions in $\mathrm{AML}$ patients should be studied in detail and probably be included in immunotherapeutic protocols against AML.

\section{ACKNOWLEDGMENTS}

The authors thank patients, nurses, and physicians on the wards for their support and the diagnostic laboratories as well as the treating institutions for the patients' diagnostic reports. Moreover, the authors thank Dr Bienemann (UniversityHospital Duesseldorf) for his advices concerning iNKT cells. The results presented in this manuscript were worked out in the doctoral theses of Corinna L. Boeck, Daniel C. Amberger, Thomas Guenther and Fatemeh Doraneh-Gard at the University Hospital Großhadern of the Ludwig-MaximilianUniversity Munich.

\section{FINANCIAL DISCLOSURES/CONFLICTS OF INTEREST}

Supported by TRANSAID-Stiftung, Elterninitiative Kinderkrebsklinik.

All authors have declared there are no financial conflicts of interest with regard to this work.

\section{REFERENCES}

1. Dohner K, Paschka P. Intermediate-risk acute myeloid leukemia therapy: current and future. Hematology Am Soc Hematol Educ Program. 2014;2014:34-43.

2. Lustosa de Sousa DW, De Almeida Ferreira FV, Cavalcante Felix FH, et al. Acute lymphoblastic leukemia in children and adolescents: prognostic factors and analysis of survival. Rev Bras Hematol Hemoter. 2015;37:223-229.

3. Hallek M. Chronic lymphocytic leukemia: 2013 update on diagnosis, risk stratification and treatment. Am J Hematol. 2013;88:803-816.

4. Robertson FC, Berzofsky JA, Terabe M. NKT cell networks in the regulation of tumor immunity. Front Immunol. 2014;5:543.

5. Pittari G, Filippini P, Gentilcore G, et al. Revving up natural killer cells and cytokine-induced killer cells against hematological malignancies. Front Immunol. 2015;6:230.

6. Schmetzer HM, Kremser A, Loibl J, et al. Quantification of ex vivo generated dendritic cells (DC) and leukemia-derived DC contributes to estimate the quality of DC, to detect optimal DC-generating methods or to optimize DC-mediated T-cellactivation-procedures ex vivo or in vivo. Leukemia. 2007;21: $1338-1341$.

7. Najera Chuc AE, Cervantes LA, Retiguin FP, et al. Low number of invariant NKT cells is associated with poor survival in acute myeloid leukemia. J Cancer Res Clin Oncol. 2012;138: $1427-1432$.

8. Grabrucker C, Liepert A, Dreyig J, et al. The quality and quantity of leukemia-derived dendritic cells from patients with acute myeloid leukemia and myelodysplastic syndrome are a predictive factor for the lytic potential of dendritic cells-primed leukemia-specific T cells. J Immunother. 2010;33:523-537.

9. Vogt V, Schick J, Ansprenger C, et al. Profiles of activation, differentiation-markers, or beta-integrins on $\mathrm{T}$ cells contribute to predict $\mathrm{T}$ cells' antileukemic responses after stimulation with leukemia-derived dendritic cells. J Immunother. 2014;37:331-347. 
10. Schick J, Vogt V, Zerwes M, et al. Antileukemic T-cell responses can be predicted by the composition of specific regulatory $\mathrm{T}$-cell subpopulations. J Immunother. 2013;36:223-237.

11. Bienemann K, Iouannidou K, Schoenberg K, et al. iNKT cell frequency in peripheral blood of Caucasian children and adolescent: the absolute iNKT cell count is stable from birth to adulthood. Scand J Immunol. 2011;74:406-411.

12. Tan JQ, Xiao W, Wang L, et al. Type I natural killer T cells: naturally born for fighting. Acta Pharmacol Sin. 2010;31: 1123-1132.

13. Montoya CJ, Pollard D, Martinson J, et al. Characterization of human invariant natural killer $\mathrm{T}$ subsets in health and disease using a novel invariant natural killer $\mathrm{T}$ cell-clonotypic monoclonal antibody, 6B11. Immunology. 2007;122:1-14.

14. Aldemir H, Prod'homme V, Dumaurier MJ, et al. Cutting edge: lectin-like transcript 1 is a ligand for the CD161 receptor. J Immunol. 2005;175:7791-7795.

15. Takahashi T, Dejbakhsh-Jones S, Strober S. Expression of CD161 (NKR-P1A) defines subsets of human CD4 and CD8 T cells with different functional activities. J Immunol. 2006;176: 211-216.

16. Alsuliman A, Muftuoglu M, Khoder A, et al. A subset of virusspecific CD161 + $\mathrm{T}$ cells selectively express the multidrug transporter MDR1 and are resistant to chemotherapy in AML. Blood. 2017;129:740-758.

17. Kim TW, Lee SE, Lim JY, et al. Clinical significance of pretransplant circulating CD3 + CD4 + CD161 + cell frequency on the occurrence of neutropenic infections after allogeneic stem cell transplantation. Transpl Infect Dis. 2017;19:e12650.

18. Fergusson JR, Huhn MH, Swadling L, et al. CD161(int)CD8 $+\mathrm{T}$ cells: a novel population of highly functional, memory CD8 + T cells enriched within the gut. Mucosal Immunol. 2016;9:401-413.

19. Kremser A, Dressig J, Grabrucker C, et al. Dendritic cells (DCs) can be successfully generated from leukemic blasts in individual patients with AML or MDS: an evaluation of different methods. J Immunother. 2010;33:185-199.

20. Schmetzer H, Stankova Z, Deen D, et al. Immunomodulation of blasts in AML-patients (AML-pts) with clinically approved response modifiers to improve antileukemic $\mathrm{T}$-cell reactivity: an ex vivo simulation of the clinical. Eur $J$ Cancer. 2015;51 (ITOC2-014):5.

21. Marenzana M, Arnett TR. The key role of the blood supply to bone. Bone Res. 2013;1:203-215.

22. Deynoux M, Sunter N, Herault O, et al. Hypoxia and hypoxiainducible factors in leukemias. Front Oncol. 2016;6:41.

23. Drolle H, Wagner M, Vasold J, et al. Hypoxia regulates proliferation of acute myeloid leukemia and sensitivity against chemotherapy. Leuk Res. 2015;39:779-785.

24. Lee CT, Mace T, Repasky EA. Hypoxia-driven immunosuppression: a new reason to use thermal therapy in the treatment of cancer? Int J Hyperthermia. 2010;26:232-246.

25. Rieger CT, Fiegl M. Microenvironmental oxygen partial pressure in acute myeloid leukemia: is there really a role for hypoxia? Exp Hematol. 2016;44:578-582.

26. Vasold J, Wagner M, Drolle $\mathrm{H}$, et al. The bone marrow microenvironment is a critical player in the NK cell response against acute myeloid leukaemia in vitro. Leuk Res. 2015;39: 257-262.

27. Deen D, Hirn-Lopez A, Vokac Y, et al. Generation of leukemia-derived dendritic cells (DC/DCleu) with clinically approved response modifiers from whole-blood (WB) samples from AML-patients (PTS): an ex vivo simulation of the clinical situation. Bone Marrow Transplantation. 2013;48:447.

28. Sato M, Takayama T, Tanaka H, et al. Generation of mature dendritic cells fully capable of $\mathrm{T}$ helper type 1 polarization using OK-432 combined with prostaglandin E(2). Cancer Sci. 2003;94:1091-1098.

29. Hirn-Lopez A, Deen D, Vokac Y, et al. Role of IFN alpha in DC-cocktails fort he generation of (leukemia-derived) dendritic cells from AML-blasts, the induction of antileukemic functionality of DC-stimulated T-cells and in correlation with clinical response to immunotherapy. Bone Marrow Transplantation. 2013;48:456

30. Guo Y, Han W. Cytokine-induced killer (CIK) cells: from basic research to clinical translation. Chin J Cancer. 2015;34: 99-107.

31. Matsuda H, Takeda K, Koya T, et al. Plasticity of invariant NKT cell regulation of allergic airway disease is dependent on IFN-gamma production. J Immunol. 2010;185:253-262.

32. Van Kaer L, Parekh VV, Wu L. Invariant natural killer T cells: bridging innate and adaptive immunity. Cell Tissue Res. 2011;343:43-55.

33. Vira S, Mekhedov E, Humphrey G, et al. Fluorescent-labeled antibodies: balancing functionality and degree of labeling. Anal Biochem. 2010;402:146-150.

34. Lopez-Sejas N, Campos C, Hassouneh F, et al. Effect of CMV and aging on the differential expression of CD300a, CD161, Tbet, and eomes on NK cell subsets. Front Immunol. 2016;7:476.

35. Eger KA, Sundrud MS, Motsinger AA, et al. Human natura killer $\mathrm{T}$ cells are heterogeneous in their capacity to reprogram their effector functions. PLoS One. 2006;1:e50.

36. Graf M, Reif S, Hecht $\mathrm{K}$, et al. High expression of costimulatory molecules correlates with low relapse-free survival probability in acute myeloid leukemia (AML). Ann Hematol. 2005;84:287-297.

37. Martner A, Rydstrom A, Riise RE, et al. NK cell expression of natural cytotoxicity receptors may determine relapse risk in older AML patients undergoing immunotherapy for remission maintenance. Oncotarget. 2015;6:42569-42574.

38. Aggarwal N, Swerdlow SH, TenEyck SP, et al. Natural killer cell (NK) subsets and NK-like T-cell populations in acute myeloid leukemias and myelodysplastic syndromes. Cytometry B Clin Cytom. 2016;90:349-357.

39. Altman JB, Benavides AD, Das R, et al. Antitumor responses of invariant natural killer T cells. J Immunol Res. 2015;2015:652875.

40. Koehl U, Kalberer C, Spanholtz J, et al. Advances in clinical NK cell studies: donor selection, manufacturing and quality control. Oncoimmunology. 2016;5:e1115178.

41. Coppola A, Arriga R, Lauro D, et al. NK cell inflammation in the clinical outcome of colorectal carcinoma. Front Med (Lausanne). 2015;2:33

42. Helms MW, Prescher JA, Cao YA, et al. IL-12 enhances efficacy and shortens enrichment time in cytokine-induced killer cell immunotherapy. Cancer Immunol Immunother. 2010;59:1325-1334.

43. Oth T, Vanderlocht J, Van Elssen $\mathrm{CH}$, et al. Pathogen-associated molecular patterns induced crosstalk between dendritic cells, T helper cells, and natural killer helper cells can improve dendritic cell vaccination. Mediators Inflamm. 2016;2016:5740373.

44. Mahmood S, Upreti D, Sow I, et al. Bidirectional interactions of NK cells and dendritic cells in immunotherapy: current and future perspective. Immunotherapy. 2015;7:301-308.

45. Pampena MB, Levy EM. Natural killer cells as helper cells in dendritic cell cancer vaccines. Front Immunol. 2015;6:13.

46. Cao J, Chen C, Wang Y, et al. Influence of autologous dendritic cells on cytokine-induced killer cell proliferation, cell phenotype and antitumor activity in vitro. Oncol Lett. 2016;12:2033-2037.

47. Veinotte L, Gebremeskel S, Johnston B. CXCL16-positive dendritic cells enhance invariant natural killer T cell-dependent IFNgamma production and tumor control. Oncoimmunology. 2016;5:e1160979.

48. Park YK, Shin DJ, Cho D, et al. Interleukin-21 increases direct cytotoxicity and IFN-gamma production of ex vivo expanded NK cells towards breast cancer cells. Anticancer Res. 2012;32:839-846.

49. Hus I, Bojarska-Junak A, Chocholska S, et al. Th17/IL-17A might play a protective role in chronic lymphocytic leukemia immunity. PLoS One. 2013;8:e78091.

50. Gottschalk C, Mettke E, Kurts C. The role of invariant natura killer $\mathrm{T}$ cells in dendritic cell licensing, cross-priming, and memory CD8(+) T cell generation. Front Immunol. 2015;6:379.

51. Matsuda JL, Mallevaey T, Scott-Browne J, et al. CD1drestricted iNKT-cells, the "Swiss-Army knife" of the immune system. Curr Opin Immunol. 2008;20:358-368. 